\title{
A GOVERNMENT FOR OUR TIME? BUSINESS IMPROVEMENT DISTRICTS AND URBAN GOVERNANCE
}

\author{
Richard Briffault*
}

The emergence and rapid spread of business improvement districts ("BIDs") is one of the most important recent developments in American cities. BIDs have been controversial, with both supporters and proponents viewing the districts as part of a trend toward the privatization of the public sector. By examining the legal and political structures that determine BID formation, functions, finances and governance, this Article determines that BIDs are not private entities but are, instead, a distinctive hybrid of public and private elements. Moreover, although the particular fusion of public and private institutions, values and concerns embodied in the BID is unique, Professor Briffault demonstrates that an interplay of public and private themes is a longstanding tradition in American local government law. BIDs depart from the norm of democratic governance and they raise questions concerning equity in the delivery of local services. BDs, however, are ultimately subject to municipal control and they provide a mechanism for providing the public services and investment that financially strapped cities need if they are to survive. With appropriate municipal oversight and limits, BIDs, and the experimentation in combining public and private roles that $B I D s$ represent, can make a significant contribution to the quality of urban public life.

InTROduction: The EMERgEnCE of BIDs ................ 366

I. The Basics of BIDs ...................... 377

A. The Law and Politics of BID Formation ........ 377

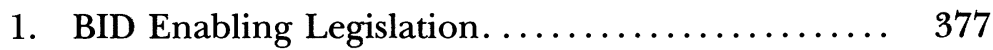

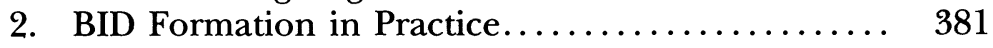

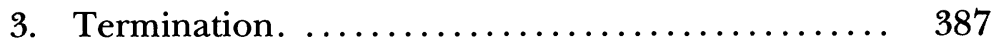

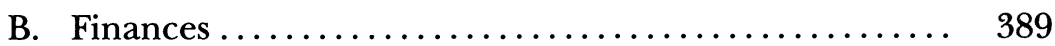

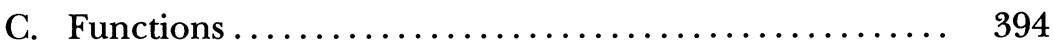

* Vice-Dean and Joseph P. Chamberlain Professor of Legislation, Columbia Law School. I undertook the initial research for this article while a Visiting Fellow at the A. Alfred Taubman Center for State and Local Government, Harvard University. I would like to express my appreciation to the members and other fellows of the Center, and especially its director, Alan Altshuler, for their hospitality and support. I would also like to thank Charles D. Star of the Columbia Law School Class of 1998 for his very helpful research assistance. This article is part of a broader project on public and private roles in local institutions which has benefitted from the encouragement and support of the Twentieth Century Fund/Century Foundation. I also benefited from the opportunity to present earlier versions of this Article at panels of the Urban, State, and Local Government Law Section of the Association of American Law Schools, the Social Science History Association, the Minnesota Law School Symposium on the Law and Economics of Federalism, and the Century Foundation. I am indebted to the assistance, comments, and collegial criticisms of too many people working with business improvement districts, in city government, and in the academic world to list them all individually here, so I will attempt to discharge that obligation with one collective acknowledgement of my gratitude to them. 
1. Physical Improvements. .................. 394

2. Traditional Municipal Services............... 395

3. Social Services........................ 401

4. Business-Oriented Services................... 404

D. Governance .............................. 409

II. The Genealogy of BIDs ...................... 414

A. Special Assessments, Special Purpose Districts, and the Legal Roots of BIDs ........................ 414

1. Special Assessments ...................... 414

2. Special Purpose Districts ................. 417

B. The BID as Urban Development Program ......... 420

1. BIDs and Postwar Urban Development Policy..... 420

2. Bringing the Suburban Shopping Mall

Downtown ............................

III. BIDs in Court: Federal and State Constitutional

Issues in BID Governance and Finances..............

A. One Person, One Vote and the Election of BID

Governing Boards .........................

B. State Tax Limitations and BID Assessments ........ 446

IV. BIDs and Public Values in Urban Governance........ 455

A. BIDs and Democratic Accountability ............ 455

B. BIDs and Inequality in Local Public Services ....... 462

Conclusion: BIDs and the Urban Public Sphere ........... 470

\section{InTRODUCTION: The EMERGENCE OF BIDs}

The Business Improvement District ("BID") is one of the most intriguing and controversial recent developments in urban governance. Combining public and private, as well as city government and neighborhood elements, BIDs undertake a diverse array of programs and services, including sanitation, policing, social services, infrastructure improvements and business recruitment and retention. In an era when "no new taxes" is a political mantra and voters regularly reject tax proposals and approve tax limitations, BIDs have been created to impose additional taxes, with the firms and landowners subject to taxation taking the leading role in establishing the BIDs. BIDs also provide for an unusual degree of neighborhood-level decisionmaking, although, unlike other forms of neighborhood government, they empower property owners or businesses rather than residents.

There are more than one thousand BIDs in the United States, ${ }^{1}$ and BIDs are active from coast to coast. There are more than forty BIDs in

1. There is no comprehensive tabulation of the number of BIDs in the United States. Indeed, given the considerable interstate variation in the powers and structure of BIDs and the fact that many states provide for the creation of local entities that perform some of the functions of BIDs but do not use the term "business improvement district," any count of BIDs is likely to be subject to challenge. Figures between one and two thousand have been used by several commentators, see, e.g., Lawrence O. Houstoun, Jr., Business Improvement 
New York City, fifty-four in Wisconsin, thirty-five in New Jersey, sixteen in San Diego, and one or more in Anchorage, Baltimore, Buffalo, Dallas, Denver, Houston, Los Angeles, Memphis, Philadelphia, St. Louis, Seattle, and Washington, D.C. ${ }^{2}$ Although the most prominent BIDs-such as New York City's Times Square BID and Philadelphia's Center City District-are located in the midtown and downtown areas of major cities, many BIDs have been established along small commercial strips within big cities, in small towns, and in suburbs.

BIDs emerged out of legal structures and concepts that go back more than a century, but the specific form of the business improvement district is a relatively recent phenomenon. Arguably, the first modern BID in the United States ${ }^{3}$ was the Downtown Development District of New Orleans, which was established in $1975 .{ }^{4}$ Most BIDs were created after 1980 , many after $1990 .^{5}$ The popularity of BIDs continued to mount throughout the 1990s. In a single recent month-September 1997newspapers reported local deliberations concerning the creation or renewal of BIDs in Cincinnati, Ohio; Madison, Wisconsin; Omaha,

Districts, 20 Econ. Dev. Commentary 4, 4 (1996) [hereinafter Houstoun, BIDs]; Richard Bradley, Downtown Renewal: The Role of Business Improvement Districts," 77 Public Mgmt. 9, 9 (1995). They should be treated as providing an order of magnitude rather than a precise measure.

2. See Recent Local Laws, 3 City Law, Nov.-Dec. 1997, at 131; Diamond District Starts a New BID, 3 City Law, May-June 1997, at 58; City Creates 5 new BIDs, 2 City Law, Dec. 1996, at 133 (BIDs in New York City); New York State Conference of Mayors (NY COM), Guide to New York State Business Improvement Districts 2 (1996) (BIDs in Buffalo) [hereinafter NY COM]; Roberta Gassman, Downtown Partners Really Are Revitalizing State Street, Capital Times, Mar. 9, 1998, at 1B (BIDs in Wisconsin); Jessica Nesterak, Downtowns are Going Back to the Future, Asbury Park Press, Sept. 21, 1997, at AA1 (BIDs in New Jersey); Ronald W. Powell, Council OKs Pacific Beach Plan, The San Diego UnionTrib., Dec. 11, 1996, at B3 (BIDs in San Diego); S. Jane Szabo, B's A-Buzzing Downtown: Brooms, Bicycles and Banners Spruce Up Heart of Anchorage, Anchorage Daily News, Apr. 27, 1998, at 2E (BIDs in Anchorage); Charter of Baltimore City, Art. II, $\S 61$ (BIDs in Baltimore); Downtown Improvement District, A Proposal to Renew Dallas' Downtown Improvement District (1995) (BIDs in Dallas) [hereinafter Downtown Improvement District]; Alan Snel, Law Would Let Golden Triangle Property Owners Raise Their Taxes, Denver Post, Sept. 23, 1997, at B6 (BIDs in Denver); Lawrence O. Houstoun, Jr., Betting on BIDs, 54 Urban Land 13, 15 (1994) [hereinafter Houstoun, Betting] (BIDs in Houston); Deborah Sullivan, Shoppers Delight: Valley to Spice Up Main Streets, Daily News of L.A., Mar. 1, 1998, at N1 (ten BIDs in Los Angeles; eleven more planned in San Fernando Valley); Cornell Christion, Council Approves Central Business District Expansion, The Commercial Appeal, Jan. 8, 1997, at 2B (BIDs in Memphis); Center City District, State of Center City 1997 (Jan. 1997) (BIDs in Philadelphia); Washington Makes a BID to Clean Up Its Image Downtown, St. Louis Post-Dispatch, Aug. 31, 1997, at 11D (BIDs in St. Louis); Retail Core Business Improvement Area, 1995/96 Annual Report (BIDs in Seattle); New Uniforms, Wash. Times, Mar. 16, 1998, at D6 (three BIDs in Washington).

3. The first BID in North America was created in Toronto in 1970. See Lawrence O. Houstoun, Jr., Business Improvement Districts 8 (1997) [hereinafter Houstoun, ULI].

4. See id. at 23-24.

5. See Janet Rothenberg Pack, BIDs, DIDs, SIDs, and SADs: Private Governments in Urban America, 10 The Brookings Rev. 18 (1992). 


\section{Nebraska; Idaho Falls, Idaho; Charleston, South Carolina; Denver, Colorado; and Nashville, Tennessee. ${ }^{6}$}

What exactly are BIDs, and why are they spreading so rapidly across the country? There is no canonical definition of a business improvement district and no single model in use nationwide. The state laws and local ordinances authorizing BIDs take differing approaches to such basic questions as district formation, functions, finances, and governance. ${ }^{7}$ Yet, most BIDs share a few basic characteristics: A BID is a territorial subdivision of a city in which property owners or businesses are subject to additional taxes. The revenues generated by these district-specific taxes are reserved to fund services and improvements within the district and to pay for the administrative costs of BID operations. BIDs' services are provided in addition to those offered by city governments. Most BIDs focus

6. See Robert Behre, Streetscape May Be Done by 2000, The Post \& Courier, Sept. 25, 1997, at B3 (Charleston); Guy Boulton \& Perry Brothers, Council Panel OKs Downtown District, Cincinnati Enquirer, Sept. 4, 1997, at B16 (Cincinnati); Jennifer Dukes, Council Approves Holiday Light Tax, Omaha World-Herald, Oct. 1, 1997, at 15 (Omaha); Gene Fadness, I.F. City Council Approves District to Redo Downtown, Idaho Falls Post Register, Sept. 26, 1997, at A1 (Idaho Falls); Rob Moritz, Proposed CBID Tax Could Hit Dead End, The Nashville Banner, Sept. 10, 1997, at B1 (Nashville); Pat Schneider, Biz Leaders Tout State St. Taxing District, Capital Times, Oct. 1, 1997, at 2A (Madison); Snel, supra note 2, at B6 (Denver).

7. Many states avoid the term "business improvement district" altogether, and instead provide for such entities as an "improvement district[ ] for enhanced municipal services," Ariz. Rev. Stat. Ann. $§ 48-575$ (West 1998); a "municipal special services district," Conn. Gen. Stat. Ann. $\$ \S 7-339 \mathrm{~m}$ to $-339 \mathrm{t}$ (West 1998); "commercial district management authority," Md. Ann. Code art. 23A, § 2(35) (1998); "special improvement district," N.J. Stat. Ann. § 50:56-66b (West 1998); Ohio Rev. Code Ann. § 1710 (West 1998); "economic improvement district," Or. Rev. Stat. § 223.114 (1993); or a "public improvement district," Tex. Loc. Gov't Code Ann. $§ 372.001$ (West 1999). In some states, no legislation authorizes BIDs per se; instead the powers of special districts and public authorities have been expanded to enable them to exercise functions associated with BIDs. See, e.g., Pa. Stat. Ann. tit. 53, $\S \S 302(1), 306(w)$ (West 1998) (Municipal Authorities Act of 1945 amended to create authorities with powers to produce and finance business improvements). Some states authorize particular BID-like districts instead of, or in addition to, adopting general enabling legislation. See, e.g., La. Rev. Stat. Ann. $\S 33: 2740.3$ (West 1998) ("Downtown Development District of the City of New Orleans").

These variations make determining how many states authorize BIDs almost as difficult as calculating the number of BIDs. The International Downtown Association states that 49 states and the District of Columbia have BID enabling legislation, see Memorandum from Jill M. Frick, Manager of Membership Services, International Downtown Association, to Richard Briffault, Vice Dean \& Professor, Columbia Law School (May 21, 1997) (on file with the Columbia Law Review), but they were unable to provide the statutory sources for a number of states. Recent commentators have disagreed on the number of states authorizing BIDs. Compare David J. Kennedy, Note, Restraining the Power of Business Improvement Districts: The Case of the Grand Central Partnership, 15 Yale L. \& Pol'y Rev. 283, 290 \& n.61 (1996) (40 states provide for the formation of BIDs) with Mark S. Davies, Business Improvement Districts, 52 Wash. U. J. Urb. \& Contemp. L. 187, 187-88 n.2 (1997) (listing 17 states that authorize BIDs and 10 states that have "passed similar legislation under different names”). My count approximates Kennedy's-about 40 states and the District of Columbia-although given the variation in district names, functions, and structure, the tabulation is imprecise. 
on traditional municipal activities, such as garbage collection, street maintenance, and security patrols. A few provide assistance to the homeless. Some engage in street repairs, undertake landscaping, provide street furniture, maintain parks, and create public amenities. Many sponsor street fairs and special events, produce promotional brochures, and engage in other direct efforts to draw shoppers, tourists, and businesses into their districts.

BIDs are funded primarily by district-specific taxes, although some enjoy other sources of financial support, including payments from governments. ${ }^{8}$ As the name implies, the property in a "business improvement district" is primarily devoted to business purposes, although many districts include some residential property. In nearly all states, establishment of a BID requires the approval of the local government, but the impetus for creating a district typically comes from neighborhood property owners or businesses, who also take the lead in mapping the district's boundaries and in developing its service and financing plan. Many states provide for property owner- or business-dominated advisory, administrative, or management boards which implement the BID's program and manage its operations.

BIDs are popular for a variety of reasons. For city governments, they provide a means of funding downtown services and improvements without raising general taxes. ${ }^{9}$ BIDs appeal to many-albeit not all-commercial area merchants and property owners because the districts kill two birds with one stone: They provide a means of solving the free rider problem that plagues the efforts of chambers of commerce and merchants' associations to raise funds to pay for services for their areas, ${ }^{10}$ while ensuring that the revenues generated by the supplemental taxes imposed on district businesses and property owners are reserved for programs these taxpayers want, and are controlled by their representatives. By assessing all properties or firms in an area, instead of depending on contributions from civic-minded volunteers, a BID provides a "stable stream of income for activities and projects" 1 - but the income is set aside for business-supported activities and projects in the district. As the executive director of one Washington, D.C. business association involved

8. These include municipal appropriations, federal and state grants, private donations, fees from the sale of BID services or the use of BID facilities, and voluntary payments by owners of tax-exempt property.

9. See Heather Barr, More Like Disneyland: State Action, 42 U.S.C. $§ 1983$, and Business Improvement Districts in New York, 28 Colum. Hum. Rts. L. Rev. 393, 397 (1997).

10. See, e.g., International Downtown Association, Business Improvement Districts 2 (1997) [hereinafter IDA].

11. Project for Public Spaces, Inc., Successful Downtown Development, Design \& Management Programs: A Compendium of Funding Tools \& Techniques 23 (1991) [hereinafter PPS]. 
in the creation of the first BID in the nation's capital put it, "[e]very penny collected for the BID goes back into the BID."12

City officials and downtown interests have found BIDs to be a lowcost tool for providing the public safety and street maintenance services urban areas need to compete effectively with suburban and edge city shopping malls, office parks, and commercial centers. BIDs do this for the most part without drawing on the general municipal treasury or diverting municipal funds from other programs. A BID can provide a neighborhood with an institutional means for crafting and implementing strategies for area development, marketing, and attracting new investment. In large cities with multiple BIDs, like New York City, Los Angeles, and Washington, BIDs may enable smaller commercial areas, which are typically overshadowed by the central business district, to articulate their distinctive concerns.

BIDs are also popular because of the widespread belief that, unlike municipal government, "BIDs [r] eally [w]ork." ${ }^{3}$ News stories regularly trumpet the successes of BIDs in tackling crime, grime, and social disorder. ${ }^{14}$ BIDs are "more effective than government," ${ }^{15}$ efficient, ${ }^{16}$ "innovati[ve],"17 and "trailblazers in solving . . . urban quality-of-life problems." 18 BIDs are credited with playing an important role in restoring urban morale and making older downtowns more attractive places to shop, visit, do business, and seek entertainment. There is actually little hard evidence that BIDs have caused property values to rise, or that property values have grown more rapidly in BIDs than in comparable areas without BIDs, but most landowners appear satisfied with BID services. ${ }^{19}$

12. Kristan Trugman, 2 Northwest Areas Seek Security in Special Taxes, Wash. Times, Jan. 6, 1997, at C5 (quoting Marcia Rosenthall, executive director of Franklin Square Association). See also David Henry \& Barbara Selvin, Other Districts Make Good on a Smaller Scale, N.Y. Newsday, Mar. 23, 1992, at 29 (quoting a merchant in the small Myrtle Avenue BID in Queens, New York: "In a sense, we've formed our own government, because all the money comes back to us.").

13. Heather MacDonald, BIDs Really Work, 6 The City J., Spring 1996, at 29, 29. States and localities cite the successes of BIDs elsewhere in authorizing new BIDs. See Del. Code Ann. tit. 22, § 1501 (3) (1997); Business Improvements Act of $1996 \S 23,43$ D.C. Reg. 1684 (1997).

14. See, e.g., Linda Feldmann, Cities Seek Disney-Style Cleanliness and Safety, Christian Sci. Monitor, Aug. 21, 1997, at 1.

15. James Traub, Can Associations of Businesses Be True Community-Builders?, 6 The Responsive Community, Spring 1996, at 29, 31.

16. See Pack, supra note 5 , at 19.

17. Fred Siegel, Reclaiming Our Public Spaces, 2 The City J., Spring 1992, at 35, 42.

18. MacDonald, supra note 13 , at 30 .

19. See, e.g., John Shors, Taking Matters Into Their Own Hands, Business Record-Des Moines, Aug. 18, 1997, at 20 (12\% of property owners opposed formation of Center City BID in 1990, but only $1 \%$ objected to 1994 renewal; only 2 out of 1400 property owners objected to renewal of Baltimore BID); Rebecca Walsh, Alliance Director Fights for Downtown, Salt Lake Trib., Aug. 3, 1997, at B1 (only 3\% of owners objected to 1994 renewal of Salt Lake City BID). Lawrence Houstoun, a leading proponent of BIDs, acknowledges the "absence of comparative research" on the effectiveness of BIDs but urges 
Even BID critics rarely challenge claims that BID programs have improved safety and sanitation within the districts. ${ }^{20}$

BIDs, however, are controversial. In New York City, for example, BIDs have been embroiled in disputes concerning the election of BID boards, treatment of the homeless, the use of BID funds to increase the presence of New York City police in the Wall Street area, and compliance with city oversight requirements. Critics contend that BIDs are undemocratic $^{21}$ and produce wealth-based inequalities in the delivery of public services. ${ }^{22}$ Many fear that areas managed by BIDs will no longer be open to the poor, the homeless, and street vendors, ${ }^{23}$ and that the successes of BIDs will further sunder the ties between rich and poor areas of large cities.

At the heart of the debate is the assumption that BIDs are essentially "private" entities. Advocates, ${ }^{24}$ critics, ${ }^{25}$ and media observers ${ }^{26}$ all join in emphasizing the private nature of BIDs. All see the rise of BIDs as reflecting and reinforcing the general trend away from the public and toward the private sector that has so marked governance in late-twentieth-century America.

that the "most telling" measure of BIDs' success "is the willingness of assessees to continue to pay." Houstoun, ULI, supra note 3, at 108-09.

20. See, e.g., Barr, supra note 9, at 396-97; David Henry, As City Cuts Services, Firms Tax Themselves to Keep Streets Clean and Safe; It Works But Is It Good Policy, N.Y. Newsday, Mar. 23, 1992, at 27 (community board chair who had opposed creation of New York City's 34th Street BID acknowledges, "It is no question that the streets are cleaner.").

21. See, e.g., Kessler v. Grand Central Dist. Mgmt. Ass'n, 158 F.3d 92, 132 (2d Cir. 1998) (Weinstein, J., dissenting) ("the constitutional threat posed by the growth of unrepresentative and non-democratically elected BIDs"); Doug Lasdon \& Sue Halpern, When Neighborhoods Are Privatized, N.Y. Times, Nov. 30, 1995, at A29 ("Business improvement districts . . . ignore democratic principles and have furthered the class divisions in our cities.").

22. See, e.g., Andrew Stark, America, The Gated?, 22 Wilson Q., Winter 1998, at 60, 75 (describing the "twin-governments trick" of exclusive gated communities like the Los Angeles suburb of Hidden Hills, and discussing the limitations of baseline service agreements that BIDs negotiate with city governments).

23. See Sharon Zukin, The Cultures of Cities 36 (1995) (BIDs "nurture a visible social stratification").

24. See, e.g., Andrew Manshel, Public Oversight: Business Improvement District Accountability, 1 City Law, Dec. 1995, at 104 (BIDs are "essentially private organizations"); John Podhoretz, An Ill-Advised Assault on an Urban Visionary, N.Y. Post, Aug. 14, 1998, at 27.

25. See, e.g., Zukin, supra note 23, at 64-66; Tom Gallagher, Trespasser on Main St. (You!), The Nation, Dec. 18, 1995, at 787 (“[BIDs have] been quietly and modestly eating away at the nation's democratic underpinnings in urban commercial neighborhoods. ....").

26. See, e.g., James Krohe, Jr., Bunker Metropolis: "Private Government" Can Deliver Good Service-For a Price, Chi. Enterprise, Sept. 1993, at 16; Thomas J. Lueck, Business Districts Grow At Price of Accountability, N.Y. Times, Nov. 20, 1994, at A1; Tony Walker, Private Sector Revitalises New York's Mean Streets, Fin. Times, July 2, 1998, at 8. 
For BID champions, the districts' private nature is the source of their success. ${ }^{27}$ Freed "of bureaucracies, entrenched interests, electoral calculations, or even ideology," BIDs are animated by the spirit of "private enterprise," 28 and "offer the virtues of the private sector" 29 to the public sector. In the words of the then-chairman of New York's Grand Central BID-the nation's largest BID in terms of the size of its budget-“[o]ur whole purpose is to help government do what it's not been capable of doing." 30 According to the Grand Central BID's general counsel, "the essential theory of the BID program . . . lies in allowing a private entity the freedom, relatively unencumbered by process and procedure, to experiment with new ideas and supplement traditional government activities in new ways." 31 Other advocates note that "much of the utility of improvement districts is related to the ability to apply business judgements" 32 and "harnes[s] private-sector creativity to solve public problems." 33

The language used by some BID proponents suggests that the districts are scarcely governmental at all, but are instead "self-help ventures" 34 or "local businesses tax [ing] themselves." ${ }^{35}$ Some states emphasize this notion of BIDs as business self-help organizations-like chambers of commerce-in the very names they give their districts: "SelfHelp Business Improvement Districts" in Alabama, ${ }^{36}$ and "Self-Supported Municipal Improvement Districts" in Iowa. ${ }^{37}$ Former Speaker of the House Newt Gingrich once capitalized on this theme, referring to BIDs as "local, voluntary, get-together organizations." 38 Other BID proponents acknowledge the public nature of BID financing yet stress that BIDs are "unencumbered by urban politics." 39

27. See Douglas Feiden, Midtown Bonds Spark BID Controversy, Crain's N.Y. Bus., Apr. 6-12, 1992, at 1, 30 (quoting statement of BID counsel that a BID is a private agency and "[t]hat's why we can run faster and jump higher" than a city agency).

28. Dan Finnigan, Private Efforts to Clean Up Downtowns May Sweep America, L.A. Times, June 25, 1992, at A5.

29. Traub, supra note 15 , at 31 .

30. See Feiden, supra note 27, at 1.

31. Manshel, supra note 24, at 106.

32. Lawrence O. Houstoun, Six Tests for State Enabling Legislation, in IDA, supra note 10 , at 36 .

33. MacDonald, supra note 13 , at 30 .

34. Richard G. Williams, Business Improvement Districts-Main Street Asset Management (visited Feb. 10, 1999) <http://www.irem.inter.net/bid> (on file with the Columbia Law Review).

35. See George L. Kelling \& Catherine M. Coles, Fixing Broken Windows 113 (1996) (BIDs "in which property owners voluntarily tax themselves"); Fred Siegel, The Future Once Happened Here 195 (1997) (describing BIDs as "local businesses tax[ing] themselves").

36. Ala. Code § 11-54B-1(a) (4) (1994).

37. Iowa Code Ann. $\S 386.1$ (West 1989).

38. Traub, supra note 15 , at 30 .

39. Houstoun, ULI, supra note 3 , at 38 . 
Critics also emphasize the private nature of BIDs, but find that to be a cause for concern, not celebration. They argue that by empowering property owners and businesses, BIDs threaten democratic control in urban areas. As a result, the turn to BIDs threatens the principle of "public stewardship" 40 of public spaces, and necessarily "represent[s] a narrowing of the public sphere." ${ }^{41}$ By offering more services to neighborhoods willing to pay more in taxes, BIDs undermine the norm of equal provision of public services. ${ }^{42}$ For their critics, BIDs are a species of privatization, first cousin to gated communities, and one more instance of the "secession of the successful" 43 that they believe is currently undermining the public sector and public life.

The conflict over BIDs mirrors the contemporary debate over the roles of the public and private sectors in American society. Yet, in its assumption of a sharp public-private divide, the argument about BIDs unintentionally reflects the limitations of that debate. Like many other aspects of governance in late-twentieth-century America, BIDs are neither wholly public nor fully private, but, rather, combine attributes of both public and private. BIDs are publicly created, they wield public powers, they provide public services, and they are subject to public control. Their empowerment of business and landowner interests and their provision of extra services to business districts based on special assessments paid within those districts, however, are distinctly "private" elements at odds with some of the basic features of public governance. Indeed, it is precisely because they are part of the public sector that the organization and financing of, and the enhanced services provided by, BIDs may seem so troubling. BIDs constitute a distinct challenge to the democratic accountability of public institutions and the equal treatment normally required in the provision of public services.

The intermingling of public and private that marks the BID has long been characteristic of local government, even if the particular synthesis represented by the BID is a new form. Local government is both the most and least "public" form of government. The small size of local governments, relative to the states and the nation, is said to afford ordinary citizens a greater opportunity to voice their views, contact and oversee elected officials, inform themselves about issues, participate in public life,

40. Zukin, supra note 23 , at 32 .

41. Howard Wolfson, New York Bets on BIDs, Metropolis: The Urban Magazine of Architecture and Design, Apr. 1992, at 15, 21 (quoting Leanne Rivlin, Professor of Environmental Psychology at the City University of New York).

42. See, e.g., Kessler v. Grand Central Dist. Mgmt. Ass'n, 152 F.3d 92, 124-25 (2d Cir. 1998) (Weinstein, J., dissenting).

43. See, e.g., Kennedy, supra note 7, at 306 (quoting the oft-cited article by Robert B. Reich, The Secession of the Successful, N.Y. Times, Jan. 20, 1991, $\S 6$ (Magazine), at 3); Richard Stengel, Bowling Together: Civic Engagement in America Isn't Disappearing But Reinventing Itself, Time, July 22, 1996, at 35 (BIDs and gated communities "represent a secession of a smaller, more privileged community from the larger one"). 
and engage in democratic self-determination. The "polis" metaphor captures this vision of local government as grass-roots democracy. ${ }^{44}$

Localities also provide the physical setting for much of public life. The streets of the city "more than any other human artifact, have come to symbolize public life, with all its human contact, conflict, and tolerance." 45 City streets, sidewalks, parks, town commons, and central squares are "our great scenes of the civic, visible and accessible, our binding agents," 46 the places where the public itself emerges out of the omnium gatherum of people of different classes, backgrounds, and beliefs. ${ }^{47}$

Yet, local government is also the most "private" level of government. Local autonomy fragments states into hundreds of jurisdictions, each focused narrowly on the well-being of the constituency within its boundaries rather than on the state or region as a whole ${ }^{48}$ each struggling with its neighbors for the resources it needs to satisfy its constituents' demands. Interlocal tax base differences can produce enormous disparities in revenues and public services. Moreover, the interlocal competition for a tax base provides mobile taxpayers-particularly businesses and affluent residents-with strategic leverage to influence local tax, service, and regulatory policies. To attract investment, local governments often focus on the provision of "the environment of private opportunity," 49 not the promotion of public discourse. Moreover, American local governments have long been closely associated with the regulation of land and the provision of services and amenities that enhance the usefulness-and the profitability - of land. Property owners, as a result, have usually played an important role in local governance.

BIDs have emerged from this longstanding interplay of public and private themes in American local government. But their distinctive combination of public and private attributes, along with the important role they play in many major cities, raises significant legal and policy issues.

44. See Richard Briffault, Our Localism: Part II-Localism and Legal Theory, 90 Colum. L. Rev. 346, 392-99 (1990) [hereinafter Briffault, Our Localism II].

45. Trevor Boddy, Underground and Overhead: Building the Analogous City, in Variations on a Theme Park: The New American City and the End of Public Space 123 (Michael Sorkin ed., 1992) [hereinafter Variations on a Theme Park].

46. Michael Sorkin, Introduction: Variations on a Theme Park, in Variations on a Theme Park, supra note 45 , at $\mathrm{xv}$.

47. As sociologist David Brain put it, "the city has been seen as both historical location and sociological bases for modern democratic politics." David Brain, From Public Housing to Private Communities: The Discipline of Design and the Materialization of the Public/ Private Distinction in the Built Environment, in Public and Private in Thought and Practice: Perspectives on a Grand Dichotomy 238-39 (Jeff Weintraub \& Krishan Kumar eds., 1997).

48. On the centrality of boundaries to the powers and duties of local governments, see Richard Briffault, The Local Government Boundary Problem in Metropolitan Areas, 48 Stan. L. Rev. 1115, 1128-32 (1996) [hereinafter Briffault, Boundary Problem].

49. Sam Bass Warner, The Private City: Philadelphia in Three Periods of its Growth 3-21 (rev. ed. 1987). 
Resolving the questions posed by BIDs may also provide some insight into the more general question of whether and how we can reconcile the growing role of private and quasi-private institutions in providing services considered public with the norms of public governance.

Parts I and II of this Article review the basic elements, and the legal and political background, of BIDs. Part I examines the state laws of BID formation, functions, finances, and governance. It provides an account of the rules, procedures, and requirements that make BIDs a distinctive legal fusion of public and private institutions, values, and concerns. Part II then provides something of a genealogy of BIDs. It considers their roots in the legal institutions of the special assessment and the special purpose district as well as in the urban development policies of the last half-century, suggests how this background affected BIDs' development, and provides a context for considering the central legal and policy questions.

Part III examines some of the federal and state constitutional problems that BIDs raise. Most states that provide for elective BID boards either limit the franchise to property owners or structure BID elections to assure property owner or business control. This would violate the one person, one vote doctrine-if that doctrine applies to BIDs. The Supreme Court has held that one person, one vote applies to local governments but has exempted many special districts from the rule. ${ }^{50} \mathrm{~A}$ BID is nominally a special district, but the wide range of BID activities and the broad impact of BIDs in their districts make the application of the special district exemption to BIDs highly problematic. In a case involving the largest BID in the United States, a divided panel of the United States Court of Appeals for the Second Circuit recently sustained the constitutionality of New York's law providing for property owner voting control of BIDs, ${ }^{51}$ but it is far from clear that this decision lays the issue to rest. I will suggest that close municipal government oversight of BIDs may justify an exemption from one person, one vote, but I acknowledge that the question is difficult and my answer relies on structures of municipal control that are impressive in theory, but may fall short in practice.

The one person, one vote challenge to BIDs assumes that property owners have too great a say in BID elections; however, most of the litigation against BIDs actually comes from property owners who claim they are unfairly burdened by BID assessments. Many state constitutions restrict property taxes in ways that would preclude the higher levels of taxation in city subunits that are characteristic of BID financing. State courts

50. See Ball v. James, 451 U.S. 355 (1981). See generally Richard Briffault, Who Rules at Home?: One Person/One Vote and Local Governments, 60 U. Chi. L. Rev. 339 (1993) [hereinafter Briffault, Who Rules at Home?] (examining the scope of federal constitutional protection of the right to vote at the local level, and factors that complicate strict application of one person, one vote to local government).

51. See Kessler v. Grand Central Dist. Mgmt. Ass'n, 158 F.3d 92, 108 (2d Cir. 1998), aff'g 960 F. Supp. 760 (S.D.N.Y. 1997). 
generally exempt special assessments from these constraints, but BID assessments often seem more like property taxes than like traditional special assessments. BID charges have, so far, survived state constitutional challenge. ${ }^{52}$ In so doing, they have contributed to a reshaping of the state constitutional law of taxation that may undermine the traditional norm of uniformity of taxation within municipal borders.

These legal issues are intertwined with and symptomatic of the broader policy questions of how BIDs fit with requirements of democratic control and equal treatment that are normally applicable to local governments. Part IV examines those policy issues. The one person, one vote question is the legal system's way of asking whether BIDs are accountable to democratic control. Although most state laws provide ample opportunities for oversight by elected municipal officials, it is unclear how effectively cities monitor the BIDs within their jurisdiction, or whether, as BID advocates maintain, more effective oversight will cripple the ability of BIDs to function. I will suggest that some legal changes can improve the prospects for effective municipal oversight, but I recognize that, at bottom, the question is one of municipal will rather than legal authority.

Similarly, the state constitutional issues point to the differences in tax and service levels within a city that result from the creation of a BID. But whereas the legal challenge to BID assessments asserts that BID property owners or businesses are being taxed too much, the policy issue focuses on the higher levels of services provided in BIDs-higher levels of service based not on greater need or on municipal determination of appropriate service levels but on the willingness and ability of businesses or property owners to pay additional taxes. ${ }^{53}$ BIDs create distinctive fiscal and service enclaves. They threaten to replicate within cities the fragmented political and fiscal structure and the interlocal public service inequalities characteristic of most American metropolitan areas. At present, BID budgets are just a small fraction of city finances, so the inequalities are relatively minor. Moreover, BID services supplement city-provided services while non-BID neighborhoods continue to receive preexisting levels of services. But once the principle of additional taxes for additional services is established, the inequalities could grow. The rise of

52. See, e.g., McGowan v. Capital Center, Inc., 19 F.Supp.2d 642 (S.D. Miss. 1998) (BID assessment not a tax and thus not subject to requirement of "uniformity" of taxation); Evans v. City of San Jose, 4 Cal. Rptr. 2d 601 (Cal. Ct. App. 1992) (BID assessment not a "special tax" subject to Proposition 13); S.O.L. Club, Inc. v. City of Williamsport, 443 A.2d 410, 411-12 (Pa. Cmwlth. 1981) (BID assessment not a tax and thus not subject to requirement of "uniformity" of taxation); City of Seattle v. Rogers Clothing for Men, Inc., 787 P.2d 39, 49 (Wash. 1990) (same). California's recently adopted Proposition 218 may have tightened the benefit-assessment nexus in ways that will be difficult for BIDs to satisfy. See infra text accompanying notes 486-499.

53. For other contemporary instances of the use of distinctive tax, service, or regulatory strategies in subcity areas, see Richard Briffault, The Rise of Sublocal Structures in Urban Governance, 82 U. Minn. L. Rev. 503, 509-17 (1997) [hereinafter Briffault, Sublocal Structures]. 
BIDs, therefore, forces us to consider the place of equality in the delivery of urban public services and whether, under what circumstances, and to what extent some wealth-based service inequality is appropriate within cities.

I conclude this Article by considering the implications of BIDs for the urban public sphere and the public/private debate. Although both advocates and critics have tended to see BIDs as a form of privatization, they are public institutions with a public mission. Emerging after decades of urban decline-and of public policies that failed to arrest that decline-BIDs are a mechanism for providing the public services and investment that financially-strapped cities need if they are to survive. Their distinctly urban focus on creating and maintaining public places that are clean, safe, and attractive has permitted them to contribute to the enhancement of the physical environment-the streets, parks, squares, and other outdoor meeting places-necessary for public life. ${ }^{54}$

Drawing on both the public and private sides of governance, BIDs are like local government generally-only more so. In an era of tightly limited city budgets, and powerful rhetorical challenges to the very legitimacy of urban government action, the BID is a public-private hybrid that can function as an asset, not a threat, to the local public sphere. To be sure, BIDs require a degree of oversight by municipal government which, however authorized by law, may be difficult to achieve in practice. The BID model of a district-level mechanism used to raise and spend additional funds entirely within that district also needs to be limited to those districts that serve a broader city interest, lest the BID device degenerate into a mechanism for increasing intracity inequality. Nevertheless, when properly monitored and limited, BIDs can advance many of the values associated with public governance.

\section{The BAsICS OF BIDs}

\section{A. The Law and Politics of BID Formation}

1. BID Enabling Legislation. - The law of BID formation varies considerably from state to state, ${ }^{55}$ but the creation of a BID generally involves

54. A leading analysis of the central role of the physical environment in healthy cities is Jane Jacobs, The Death and Life of Great American Cities (1961).

55. The rules may even vary considerably within one state. Several states-California, Pennsylvania, and Texas-provide more than one means of creating BIDs and BID-like bodies. Compare Parking and Business Improvement Area Law of 1965, Cal. Sts. \& High. Code $\$ \S 36000-36081$ (West 1969), with Parking and Business Improvement Area Law of 1989, Cal. Sts. \& High. Code $\S \S 36500-36551$ (West Supp. 1999), and Property and Business Improvement District Law of 1994, Cal. Sts. \& High. Code $\S \S 36600-36651$ (West Supp. 1999). Compare Tex. Loc. Gov't Code Ann. $\S \S 372.001-372.030$ (West 1988) (public improvement districts), with id. $\$ \S 375.001-375.281$ (West Supp. 1999) (municipal management districts). Compare Pennsylvania Municipality Authorities Act of 1945, Pa. Stat. Ann. tit. 53, §§ 301-322 (West 1997) (amended 1980), with Business Improvement District Act of 1996, 53 Pa. Cons. Stat. Ann. $\$ \S 5401-5406$ (West 1997) (originally enacted as Business Improvement District Act of 1967, Pa. Stat. Ann. tit. 53, $\S 1551$ ). 
formal actions by both the city government and the private sector. Property owners or businesses-depending on whether the BID is financed by taxes on property or on business-typically initiate the process and play the leading role, but the rules and procedures are determined by state and city governments, and, in nearly all jurisdictions, the consent of the city government is necessary to establish the BID. Although many commentators claim BID formation requires a majority vote of property owners (or businesses) in the proposed district, ${ }^{56}$ formal private sector approval is often not necessary, and district-level voting on the creation of a BID is rarely required. ${ }^{57}$ Still, a BID is not likely to be established without substantial district-level private sector support.

The BID formation process is typically initiated by a petition signed by the owners of some significant fraction of the property (or businesses) that would be subject to BID assessment. The petition proposes the district's boundaries and outlines basic aspects of its financial and service plan. The states vary with respect to the degree of district-level support needed to initiate the process, ranging from as little as twenty percent, ${ }^{58}$ to as much as two-thirds, ${ }^{59}$ of property (or business) interests in the district, with most states requiring the support of a majority. ${ }^{60}$ The most common denominator for measuring support is property in the district weighted according to assessed valuation ${ }^{61}$ or to the assessment the owner would pay. ${ }^{62}$ Some states, however, look to the number of owners,

56. See, e.g., Houstoun, Betting, supra note 2, at 16 ("In most cases, state law requires some form of vote by those affected, either before or after the city council passes an enabling ordinance."); Simon Jenkins, What London Can Learn From New York, Evening Standard, Sept. 6, 1996, at 9 ("Businesses within a defined neighbourhood have been asked if they wish to vote for a committee with the power to surcharge their local rates to improve local services."); Lueck, supra note 26, at A1 (BIDs created by a vote of property owners); Alan Pike, A Private Tax for Cleaner Streets, Fin. Times, Jan. 9, 1997, at 22 ("[s]etting up a BID requires majority support in a vote of businesses in the district"). A more sophisticated error is that a majority of district property owners must petition for a BID. See Herbert Hadad, Business Groups Reclaiming Inner-City Districts, TimesPicayune, Nov. 14, 1996, at A13. In some states, the requirement is well below a majority of property owners, and in some states a petition is not required.

57. One case in which a vote is necessary is Baltimore, where the amendment to the Baltimore City Charter adopted by the Maryland legislature conditions the effectiveness of any Baltimore ordinance establishing the Downtown Commercial District Management Authority on approval, in an election, by the owners of properties subject to BID charges.

58. Ind. Code Ann. § 36-9-38-8 (Michie 1998) (a petition filed by the owners of $20 \%$ of the surface area of the real property of the proposed district is sufficient to trigger the process provided the associations also include the owners of 15 separate parcels).

59. Ala. Code $\S 11-54 B-5(a)$ (1975).

60. See, e.g., Cal. Sts. \& High. Code $§ 36621$ (a) (West 1998); Colo. Rev. Stat. § 31-251205 (1996); Ga. Code Ann. § 36-43-5 (1) (1993); Idaho Code § 50-2603 (1998); Mass. Ann. Laws ch. 40O, § 3 (Law. Co-op. 1998); W. Va. Code § 8-13A-6 (1998).

61. See, e.g., Ala. Code $\S 11-54 B-5$ (a) (1975). (1998).

62. See, e.g., Cal. Sts. \& High. Code $\S 36621$ (a) (West 1998); Idaho Code $§ 50-2603$ 
the number of parcels, the land area, or to some combination of property value and the number of parcels or owners. ${ }^{63}$

Once petitions with the requisite number of signatures are filed, the matter goes to city hall. The creation of a BID usually requires the enactment of a local law or ordinance. That ordinance will typically track the BID petition, and will address such basic questions as the BID's boundaries, functions, budget, and financing formula. ${ }^{64}$ Typically, the municipality can shrink, but not expand, the area within the BID, or reduce, but not increase, the proposed assessments. The decision whether to create the BID is a matter of city discretion: Even overwhelming private sector support within the proposed district cannot force the municipality to establish the BID. ${ }^{65}$

In many states, city hall action is not the final step. Landowners (or businesses if they are subject to assessment) may get an opportunity to veto the municipality's approval of the proposed BID. District landowners or businesses subject to assessment may block the BID if a significant fraction of them file written protests within a specified period of time. ${ }^{66}$ As with the initiating petitions, the state protest provisions vary, with most requiring a majority of the private sector interest subject to assessment, measured by number of owners or assessed valuation, to sign protests in order to block a municipally authorized BID. ${ }^{67}$ Although landowners (or

63. See, e.g., D.C. Code Ann. $§ 11-242-4$ (1997) (owners of $51 \%$ of assessed valuation and $25 \%$ of the number of individual properties); Iowa Code Ann. $\S 386.3$ (West 1998) (25\% of owners and $25 \%$ of assessed valuation); Mass. Ann. Laws ch. 40O, $§ 3$ (Law. Co-op. 1998) $(51 \%$ of assessed valuation and $60 \%$ of owners); Minn. Stat. Ann. $\S 428$ A.08 (West 1998) (owners of $25 \%$ of land area and owners of $25 \%$ or more of net tax capacity of the district); Neb. Rev. Stat. § 19-4026 (1997) (owners of 30\% of assessable front footage or users of $30 \%$ of space in business area); N.M. Stat. Ann. § 3-63-6 (Michie 1995) (majority of the real property by assessed valuation and real property owners within the proposed district); Tenn. Code Ann. $§ 7-84-511$ (1992) (majority of owners and two-thirds of assessed valuation); Tex. Loc. Gov't Code Ann. $\$ 375.022$ (West 1999) (majority of the real property by assessed valuation or 50 owners of real property).

64. The failure of a city council to specifically set forth by ordinance the improvements to be made by the BID and the estimated costs of those improvements led the Nebraska Supreme Court to invalidate a BID in Foote Clinic, Inc. v. City of Hastings, 580 N.W.2d 81, 85-86 (Neb. 1998).

65. But cf. Ariz. Rev. Stat. Ann. § 48-575(C) (West 1998) (municipality "shall" create a BID proposed by a petition signed by all property owners in the district).

66. In some states, the protest period falls between two actions of the local legislature. In these states, the local government passes a preliminary resolution outlining the boundaries and financial plan of the proposed BID, and then must wait a period of timetypically 30 to 60 days-in which protests may be filed. If the number of protests received falls below the statutory threshold, then the municipality may proceed to final enactment of the ordinance creating the BID. See Cal. Sts. \& High. Code $\$ 36625$ (West 1999). In other states, the municipality may create the BID, but the district does not become effective until after the period for filing written protests has elapsed. See Ala. Code § 1154B-7.

67. See, e.g., Cal. Sts. \& High. Code $§ 36625$ (West 1999); Idaho Code $§ 50-2606$ (1994); Mont. Code Ann. § 7-12-1114 (1997); Neb. Rev. Stat. § 19-4027 (1997); N.M. Stat. Ann. § 3-63-8 (Michie 1995); Wash. Rev. Code Ann. § 35.87A.060 (West 1998). Some states 
firms) can veto a BID approved by the city, they cannot overturn a municipal decision to reject a BID that received sufficient district-level petition support to qualify for municipal consideration.

Not all states offer this combination of private initiation, public action, and opportunity for private protest. Some provide for initiation by district petitions but not for district protests. ${ }^{68}$ In other states, the city government may take the initiative, without waiting for a petition, but district owners (or businesses) can petition to block the BID. ${ }^{69}$ Where an initiating petition is not required, district-level private sector input in BID development may be formalized by a "district planning commission" 70 or "business improvement board" 71 composed of firms or landowners from the area considered for a BID. Its recommendations concerning district boundaries, functions, and finances will frame the city government's deliberations. ${ }^{72}$

Not all states require both public and private action. In some states, a BID may be created either by the city government alone, without a district-level petition or an opportunity for district protests to block the BID. ${ }^{73}$ These states may require the municipality to give special notice and an opportunity for comment to property owners (or firms) in the area in which it intends to create a BID, ${ }^{74}$ or direct the city to appoint an advisory board composed of district-level business or property interests to make recommendations concerning the BID's services and finances. ${ }^{75}$

enable protests by a smaller fraction of property or business interests to block a BID. See, e.g., Ala. Code $\S 11-54 \mathrm{~B}-7$ (1994) (protests by owners of one-third of parcels); Minn. Stat. Ann. $\$ 428$ A.09(2) (West 1999) (owners of $35 \%$ of the land area in the district subject to assessment or owners of $35 \%$ of the net tax capacity of district property may block formation of a special services district approved by local ordinance); Wis. Stat. Ann. $\S 66.608(2)(d)$ (West 1990) (owners of $40 \%$ of assessed valuation). Some require significantly more than $50 \%$ to block the BID. See, e.g., Tex. Loc. Gov't Code Ann. $\S 372.010$ (c) (West 1988) (two-thirds of owners or owners of two-thirds of property).

68. See, e.g., Colo. Rev. Stat. Ann. § 31-25-1207 (West 1998); Ga. Code Ann. § 36-43-5 (1993); Ky. Rev. Stat. Ann. § 91.754 (Michie 1996).

69. See, e.g., Cal. Sts. \& High. Code $§ 36525$ (West 1999); Kan. Stat. Ann. § 12-1789 (1991 \& Supp. 1997); Or. Rev. Stat. § 223.117 (1993); S.D. Codified Law, § 9-55-10 (Michie 1995). In Pennsylvania, property owners may not block formation of a business district authority, but written protests by the owners of one-third of the benefited properties in the district, or by the owners of one-third of the valuation of the benefited properties, may block the municipality from enacting the business district authority's plan, e.g., its budget and proposed method of assessment. See Pennsylvania Downtown Center, Forming a Business District Authority in Pennsylvania 8-10, 25 [hereinafter PDC] (updated manual explaining the business district authority law and its application).

70. See, e.g., Kan. Stat. Ann. § 12-1785 (1991). 1995).

71. See, e.g., Neb. Rev. Stat. § 19-4021 (1997); S.D. Codified Laws § 9-55-5 (Michie

72. See, e.g., N.M. Stat. Ann. §§ 3-63-9 to -10 (Michie 1995).

73. See, e.g., Del. Code Ann. tit. 22, § 1503 (1997); N.H. Rev. Stat. Ann. § 31:121 (1988 \& Supp. 1996); N.J. Stat. Ann. § 40:56-66 (West 1992); Okla. Stat. §39-103.1 (1992).

74. See, e.g., N.J. Stat. Ann. § 40:56-71 (West 1992).

75. See, e.g., N.H. Rev. Stat. Ann. § 31:122 (1988 \& Supp. 1996). 
However, special notice to, or input from, district interests is not always required. ${ }^{76}$

The only state that makes no provision for local government involvement in the creation of a BID, and also one of the very few states that provides for district-level input by election rather than through petition, is Mississippi. Under a law enacted in $1995,{ }^{77}$ the process is triggered by a petition signed by at least twenty percent of the property owners in an area. ${ }^{78}$ They are then required to call a meeting of property owners within the proposed district. The BID will go forward only if a majority of the property owners in attendance agree on a plan of boundaries, improvements, assessments, and governance. ${ }^{79}$ That plan, in turn, must be submitted to a vote by the district's property owners. The BID is established if approved by those who would pay seventy percent of the district's assessments. ${ }^{80}$ The municipal role is limited to a public hearing before the election to review the plan and receive public comments and, after the election, to the mayor's review of the plan to determine whether it complies with the statute's prescriptions. ${ }^{81}$

2. BID Formation in Practice. - The formal legal rules of BID formation tell only part of the story. Even in states that do not require a neighborhood petition, some district-level property owner or business initiative is usually necessary to start the process, and a private sector proposal generally shapes whatever district the city government ultimately adopts. ${ }^{82} \mathrm{~A}$ study of thirteen BIDs in six states, including some that do not have a petition provision, found that "the initiative comes from business leaders," and BID boundaries, programs, finances, and governance structures grow out of "business world intramural discussion." 83

76. See, e.g., Del. Code Ann. tit. 22, § 1503 (1997).

77. Mississippi Business Improvement District Act, 1995 Miss. Laws 442 (codified in Miss. Code Ann. at $\S \S 21-43-101$ to -133 (Supp. 1998)).

78. Id. at $\S 21-43-111$.

79. Id. at $\S 21-43-113$.

80. Id. at $\S \S 21-43-115$ to -119 . Although votes are weighted according to assessments, no single property owner's vote may exceed one-third of the total number of votes which may be cast. Id. at $\$ 21-43-115$.

81. Id. at $\S 21-43-117(6)$. The Mississippi law appears to be onerous in practice. The first BID proposed for the state, in downtown Jackson, failed in 1995 when it received support from property owners representing $61 \%$, but not the statutory $70 \%$ of square footage. See Nita McCann, For Second Year in a Row, Downtown Property Owners Debate BID, 18 Miss. Bus. J. If 5 (May 13, 1996) <http://www.msbusiness.com/mbj051396/ BID.html> (on file with the Columbia Law Review). On a second try, with boundaries reconfigured to exclude some opponents, the BID received $74 \%$ of the square footage vote. See Will Pinkston, Vote Makes Business Improvement District a Reality in Jackson, Clarion-Ledger, July 4, 1996, at 1A. City voters unsuccessfully challenged this procedure under the federal Voting Rights Act. See Parker-Weaver v. Fordice (S.D. Miss. 1998) (unpublished), aff'd mem., 119 S. Ct. 791 (1999).

82. See, e.g., PDC, supra note 69, at 12 ("the private sector should lead the initiative").

83. Houstoun, Betting, supra note 2, at 14-16. 
The impetus for a BID may come from one or a handful of leading businesses or institutions; ${ }^{84}$ from a developer seeking enhanced municipal services to make a new project more marketable to potential tenants; 85 from a not-for-profit community development corporation or more loosely organized community groups; ${ }^{86}$ or, most commonly, from an existing downtown association, chamber of commerce, merchants' association, or public-private partnership. ${ }^{87}$ The downtown association may push for the BID to promote downtown revitalization, or from the more self-interested hope that it will be hired to manage the BID and, thus, be able to rely on BID assessments for funding instead of having to struggle to raise voluntary donations from merchants or realtors. ${ }^{88}$ The city government may also take a role in starting the process. City officials may prod business figures to form a BID to finance services or improvements in neighborhoods critical to the city's economy, ${ }^{89}$ and city officials may be involved in the formulation of the BID's program. ${ }^{90}$ In Los Angeles,

84. New York's 14th Street-Union Square BID-the first New York City BID created pursuant to state general enabling legislation-was "the joint initiative of the heads of the Consolidated Edison Company, the Guardian Life Insurance Company, and the New School." Douglas Martin, Districts to Improve Business Proliferate, N.Y. Times, Mar. 25, 1994, at B3. See also MacDonald, supra note 13, at 32 (describing the creation of the Grand Central BID).

85. See, e.g., Edward T. Rogowsky et al., New York City's Outer Borough Development Strategy: Case Studies in Urban Revitalization, in Urban Revitalization: Policies and Programs 69 (Fritz W. Wagner et al. eds., 1995) (noting that Forest City Enterprises, the developer of the multimillion dollar Metrotech office park in downtown Brooklyn, "took the lead in organizing a Business Improvement District, including the Metrotech development and a few surrounding institutions in order to provide a high level of services and organizational support").

86. See, e.g., New York City Dep't of Bus. Services, Establishing and Operating a Business Improvement District: A Step-By-Step Guide 1 (1996) [hereinafter DBS Guide] ("Regardless who initiates the BID, however, no BID effort will succeed without the active support of a local sponsoring organization. ..."); John Holusha, Making A BID to Improve a Bronx Neighborhood, N.Y. Times, Dec. 8, 1996, at R7 (discussing evolution of community anti-graffiti campaign into "a full-blown business improvement district").

87. See, e.g., PDC, supra note 69 , at 12-13; Houstoun, Betting, supra note 2, at 16 ; Pike, supra note 56, at 22 (Baltimore BID grew out of Downtown Partnership); Profitable Partnership: Downtown Group Did Much More Than Just Save Itself, Pittsburgh PostGazette, Jan. 22, 1997, at A10 (creation of Pittsburgh BID provided funding needed by Pittsburgh Downtown Partnership).

88. See, e.g., Cliff Peale, Council is Last Hurdle for Downtown District, Cincinnati Post, Aug. 7, 1997, at 6B (on the role of Downtown Cincinnati, Inc. in pressing for the creation of the Downtown Cincinnati Improvement District); Leah Beth Ward, Downtown: Property Owners Debate Need for Tax; "Privatized" District Could Attempt to Solve Specific Problems, Cincinnati Enquirer, Aug. 25, 1996, at J1 (same).

89. See, e.g., MacDonald, supra note 13, at 33 (New York City's mayor urged business leaders to form what became the Grand Central BID); PDC, supra note 69, at 13 (describing the leading role of mayor of Mount Pleasant in forming that city's BID).

90. In New York City, for example, the Department of Business Services ("DBS") insists on being "involved from the outset of the BID effort." DBS Guide, supra note 86, at 2. DBS itself "frequently presents the BID Program at the first meeting of the local sponsor." Id. 
the city provides sponsors with seed money to assist in the development of the BID plan and in its initial presentation to property owners. ${ }^{91}$

The creation of a BID usually requires proponents to invest considerable time, energy, and funds. New York City's Department of Business Services ("DBS") - the agency responsible for overseeing the City's BID program-notes that "no BID effort will succeed without the active support of a local sponsoring organization which is willing to undertake the work." 92 According to DBS's guide to BID formation, the sponsor ought to select a project leader and a steering committee who will be responsible for proposing district boundaries; for assembling a detailed database on the property owners, properties, and merchants within the proposed BID; for determining the BID's services, budget, and assessments; and for building support for the BID within the proposed district. ${ }^{93}$ The sponsor will need to hire consultants to inventory the district's properties to determine uses, vacancies, and other factors relevant to the BID's finances; to undertake studies to determine whether the area can sustain additional assessments and whether the service program will benefit owners; and to develop a strategy to win the support of those who would be subject to BID taxation. ${ }^{94}$ DBS reviews the contents of the BID proposal, requires the sponsor to develop a community outreach plan, and assesses the adequacy of the sponsor's mailings, meetings, and use of media to notify property owners in the proposed district.

In practice, local governments may press proponents to demonstrate greater district-level private sector support for the BID than state or local law requires. Although New York law requires the support of just a majority of potential assessment payers as a condition for public approval of a BID, New York City's DBS will not allow a BID proposal even to begin the statutory public approval process unless the agency is provided with "documented support of a supermajority of property and business owners" 95 - with "supermajority" typically meaning at least eighty percent. ${ }^{96}$ In other cities, too, "consensus"-that is, more support from property

91. See, e.g., Darrell Saltzman, Funds Allocated to Study Improvements, L.A. Times, July 25, 1996, at B3 (Los Angeles city council appropriates $\$ 225,000$ to pay for consultants to assist in planning BIDs for Chatsworth, Northridge, and Granada Hills).

92. DBS Guide, supra note 86 , at 1.

93. See id. at 1-13. Similarly, according to a manual prepared by the New York City Partnership, the first step in starting a BID is the formation of "[a]n initial core group of property owners, business people, and commercial tenants" known as the "sponsor" to prepare the district plan, build support for the proposal within the district, and move the proposal through the statutory approval process. See New York City Partnership, The Bid Manual: Establishing and Managing a Business Improvement District 2, 5 (1995) [hereinafter The BID Manual].

94. See PPS, supra note 11, at 24-26.

95. Id. at $2,13$.

96. See The BID Manual, supra note 93, at 10. Even this may not be enough to assure consensus. In 1996 and 1997, DBS submitted two BID proposals to the City Council which drew sufficient property owner objections that the Council was required to disapprove the BIDs. See Council of the City of New York, Managing the Micropolis: Proposals to 
owners or businesses in the district than the statutory minimum of a simple majority-may be required in practice before the city government will approve a BID proposal. ${ }^{97}$

Such consensus usually takes time to achieve. According to one manual on BID formation, "the door-to-door communication about the district plan and program must be thorough and relentless."98 A study of BIDs in five large cities found the process took an average of sixteen months. ${ }^{99}$ In New York City, it takes closer to three years, ${ }^{100}$ with nine to twelve months for the hearings, waiting periods, reviews, and opportunities for written protests that are mandated by law, ${ }^{101}$ and eighteen months to two years consumed by the sponsor's development of the plan, community outreach, revision of the plan in light of community responses, documenting of the necessary support, and review by DBS prior to submission to the public approval process. ${ }^{102}$ The creation of Philadelphia's Center City BID took five years. ${ }^{103}$

BIDs are not always welcomed with open arms by district property owners or merchants. ${ }^{104}$ The BID proposal may trigger an intense debate over the quality of existing public services, the burdens to individual owners of the proposed assessments, and the economic value of the proposed services. Some business or property owners will oppose a BID. The owners of large office buildings, who would often pay the largest assessments, may already be providing the supplemental sanitation and security services that the BID would offer. ${ }^{105}$ At the other end of the economic spec-

Strengthen BID Performance and Accountability 7-10 (1997) [hereinafter Managing the Micropolis].

97. See, e.g., Oregon Downtown Development Association, Economic Improvement Districts At Work in Oregon 8 (1988) [hereinafter ODDA]; Mike Dries, Map to the Future, Bus. J. 1, Dec. 21, 1996, at 8, 10 (discussing requirements for BID proposals in Milwaukee, Wisconsin).

98. PDC, supra note 69, at 23.

99. See Houstoun, Betting, supra note 2, at 18. In a later article, Houstoun reported that a year and a half is the typical amount of time it takes to form a BID, with some BIDs requiring two years or more to establish. See Houstoun, BIDs, supra note 1 , at 9 .

100. See Houstoun, Betting, supra note 2, at 18.

101. See DBS Guide, supra note 86 , at 13-14; The BID Manual, supra note 93, at exh.6.

102. See DBS Guide, supra note 86, at 12; The BID Manual, supra note 93, at 23.

103. See PDC, supra note 69, at 24.

104. See id. at 10 ("In every city, some property owners opposed the EID [economic improvement district-Oregon's term for a BID].”).

105. See, e.g., ODDA, supra note 97, at 6 ("The most dangerous group is comprised of large, property-owner occupied businesses."); McCann, supra note 81, I 2 ("Major property owners whose buildings were already sparkling clean and full of tenants and who provide their own security did not see the point of paying an annual 9-cent-per-square-foot fee to provide services for the whole of downtown Jackson."); Clifford Carlsen, Brighter Economy Dims Outlook For Downtown Clean-Up Tax, S.F. Bus. Times, July 19, 1996, at 5 (lack of support from large hotels, which would have been subject to largest assessments, contributed to defeat of proposed Center City District BID in San Francisco); Claudia H. Deutsch, Tug-of-War Over A Business Improvement District, N.Y. Times, Jan. 8, 1995, § 9 , at 9 (quoting the vice president of one large office tower, "We steam-clean our sidewalks, 
trum, small merchants, ${ }^{106}$ parking lot owners, ${ }^{107}$ and the "owners of tiny lots and rundown vacant buildings" are reluctant to pay assessments "on top of taxes they already claim are too burdensome." 108 Owners of factories and industrial properties, who have few walk-in customers, may believe they will receive little benefit from the additional trash pick-up, street cleaning, and graffiti removal that the BID is intended to provide. ${ }^{109}$ Many owners are concerned about subjecting themselves to new taxation and resent having to make an additional payment to finance services they think should be paid for out of their existing tax dollars. ${ }^{110}$ Some, particularly the owners of residential property, may be unable to pass on the BID's costs to tenants or customers. ${ }^{111}$ Even when owners agree about the value of a BID in principle, they may clash over the level of taxation, the assessment formula, or the BID's programmatic priorities.

As the proposal moves forward, the BID's boundaries may have to be redrawn, ${ }^{112}$ its service plan and budget cut back, ${ }^{113}$ and its assessment mechanism revised to ease the burden on objectors. ${ }^{114}$ Consensus may

we patrol our streets, the city police and sanitation people work the area. We do not feel a BID is needed here."). At the end of 1998, San Francisco appears to be on the verge of reversing the 1996 rejection, and approving a BID for the Union Square, effective early 1999. See Edward Epstein, Improvement District Tax Plan Endorsed, S.F. Chron., Dec. 3, 1998, at A29.

106. See Kara Swisher \& Rene Sanchez, "BIDs" Backed as Solution to Downtown Blight: Business Improvement Districts Gain as Private-Sector Way to Revitalize City's Core, Wash. Post, Apr. 14, 1992, at D1 (quoting owner of a shoe store, "We have our own problems paying bills and taxes and other fixed costs we now have.").

107. See, e.g., Dan Monk, Critics Claim Taxing District Lacks Support, Cincinnati Bus. Courier, Aug. 1, 1997, at 3 (noting that parking companies opted not to sign Downtown Cincinnati Improvement District Petitions because the financing scheme, which collected $25 \%$ of the assessment from front footage, imposed a big hit on surface lots).

108. McCann, supra note 81 , I 3 .

109. See, e.g., Lois Weiss, BID Fever Not Spreading in Long Island City, Real Estate Wkly., July 7, 1993, at 1 .

110. See ODDA, supra note 97 , at 7 ; Ward, supra note 88 , at $\mathrm{J} 1$.

111. Many states limit BIDs to commercial or business districts, but the separation of business and residence is rarely total, and residential parcels may be found in commercial areas. Some states exempt residential parcels from assessment or limit their assessments to nominal amounts. Owners of exempt parcels may not be given a voice in the BID formation process. But where residential owners are subject to assessment their consent must also be sought.

112. See, e.g., Mound Hardware v. City of Spokane, 1997 Wash. App. LEXIS 1940 (Ct. App. Wash., Div. 3, 1997) at *4; ODDA, supra note 97, at 5 (advising BID proponents to "be realistic about potential opponents and develop boundaries accordingly"); Henry, supra note 20, at 27 ("The zig-zag boundaries on the 34th Street map illustrate the cajoling of property owners that goes into establishing a district. ... Organizers have been willing to exclude properties on the fringes to avoid a fight.").

113. See, e.g., Mound Hardware, 1997 Wash. App. LEXIS at 5; Dan LeRoy, Revised Urban Plan Gets More Support, Charleston Daily Mail, Sept. 2, 1997, at 1A.

114. See ODDA, supra note 97, at 6 (use of graduated assessment levels to reduce opposition); Henry, supra note 20, at 27 (major retailers assessed at two-thirds rate of 
not be reached, and the BID may be aborted. ${ }^{115}$ Even if the city authorizes the BID, property owner opponents may continue the fight by mustering written protests ${ }^{116}$ or taking the matter to court. ${ }^{117}$

City governments are generally inclined to approve BIDs that enjoy district-level business backing, ${ }^{118}$ but city officials may lower the proposed assessment, ${ }^{119}$ redraw the boundaries to reduce the number of property owners subject to assessment, ${ }^{120}$ or even reject a BID that satisfies the formal statutory requirements. ${ }^{121}$ This is most likely to occur where state law measures business support in terms of the assessed valuation of the property at stake, rather than the number of owners. A relatively small number of major landowners may control the share of property legally required for district approval when property is calculated in terms of assessed value. But as a political matter, elected city officials may be reluctant to act unless there is support from a substantial fraction of all property owners, large and small. ${ }^{22}$

office buildings). Many states permit a variety of assessment mechanisms, so sponsors may be able to choose a method less burdensome to a particular type of property owner.

115. See, e.g., ODDA, supra note 97, at 10 (failed BID proposals in Oregon); Houstoun, BIDs, supra note 1, at 9 (six New Jersey BIDs "abandoned in the planning stage"); Edward Epstein, Patrol Sweeps Up Downtown S.F., S.F. Chron., Oct. 23, 1996, at A13 (discussing a "misfired attempt" to create a BID in downtown San Francisco); Dan LeRoy, Retailer Says Plan for District is Dead But Councilman Says Opposition is Not Reason It's Off Agenda, Charleston Daily Mail, Sept. 12, 1997, at 4B ("outcry from property owners" led to halving of BID program, but reduced proposal still failed due to lack of property owner support).

116. See, e.g., Easley v. City of Lincoln, 330 N.W.2d 130, 135 (Neb. 1983) (finding that trial court erred in calculating percentage of landowners who protested); North Star Lodge No. 227 v. City of Lincoln, 322 N.W.2d 419, 422 (Neb. 1982) (“[H]ad the statute been properly interpreted and followed" the contested proceedings would have terminated "due to the filing of written protests by more than the statutorily required 50 percent of assessable unit owners.").

117. See, e.g., Nesterak, supra note 2, at AAl (lawsuit by commercial property owners in Freehold, N.J. who did not believe that they would benefit from BID as much as district retailers).

118. See Houstoun, Betting, supra note 2, at 16.

119. See, e.g., Rob Moritz, Proposed CBID Tax Could Hit Dead End, Nashville Banner, Sept. 10, 1997, at B1 (Nashville City Council considering reduction in assessment for proposed Central Business Improvement District from the level supported by the $58 \%$ of downtown property owners who signed petition calling for creation of the CBID).

120. See, e.g., Larry Compton \& Sally Compton, Anchorage Assembly Erred on BID Borders, Anchorage Daily News, Sept. 4, 1997, at 7B (criticizing Anchorage city government for reducing area of Downtown Business Improvement District despite approval of larger boundaries by a majority of property owners within the proposed BID).

121. See Managing the Micropolis, supra note 96, at 7-10 (noting that although 25 objections to the Noho BID came after the statutory deadline and were insufficient as a matter of law to block the BID, the City Council persuaded the sponsor to cut the cost of the program by $35 \%$ and to change the composition of the BID governing board to give greater representation to commercial property owners).

122. See Guy Boulton \& Perry Brothers, Council Panel OKs Downtown District, Cincinnati Enquirer, Sept. 4, 1997, at B16 (Cincinnati Council finance committee approved creation of Downtown Cincinnati Improvement District on petition signed by 
Ordinary residents-and even commercial tenants in a BID that would be financed by property taxes-have little formal role in the process. Their signatures have no legal weight in petitions for a BID or in written protests to block one. BID-sponsor outreach efforts are focused on property, although merchants, noncommercial neighborhood associations, not-for-profit development corporations, and community planning boards may be contacted during the BID formation process. Residents are heard, if at all, at the public hearings that most states require city councils or other municipal bodies to conduct as part of the public process of BID formation. ${ }^{123}$ Even then, in many jurisdictions statutory notice requirements are focused on reaching the property owners or businesses who would be subject to BID assessments rather than district residents generally.

Still, although the process of BID formation tends to be dominated by landowners or business interests-and significant private opposition will usually block a BID-the ultimate decision in nearly all states is a public one. Private interests can propose a BID, but for the most part only a municipal government can create one.

3. Termination. - The provisions governing the termination of the BID underscore the extent to which BIDs require the ongoing support of both district business or property interests and city hall. However, in contrast to BID formation, which is likely to require both public and private action, many states permit the termination of districts by either the city government or the district private sector acting independently.

In a number of states, a BID is established for a limited period. Typically, the term is five years, ${ }^{124}$ although in some states it is ten years, ${ }^{125}$ and Delaware permits its municipalities to create BIDs with up to thirtyyear terms. ${ }^{126}$ Many states also provide for renewal or reauthorization of the BID when the initial term expires. This may entail compliance with the standards and procedures-including the property owner petition

owners who would pay $70 \%$ of proposed district assessment, even though Ohio law required support from just $60 \%$. The successful petition, representing owners of $70 \%$ of assessable property, also represented $47 \%$ of property owners. An earlier petition, bearing the signatures of property owners accounting for $61 \%$ of assessed valuation, had been criticized because only $34 \%$ of all owners had signed the petition, with the 5 largest property owners in downtown Cincinnati accounting for half the assessed valuation.) See Dan Monk, Critics Claim Taxing District Lacks Support, Cincinnati Bus. Courier, Aug. 1, 1997 , at 3 .

123. In New York City, for example, community planning boards are given the opportunity to conduct public hearings and submit written recommendations to the city planning commission on BID proposals before the City Council can act. See N.Y. Gen. Mun. Law § 980-d (McKinney Supp. 1999).

124. See, e.g., Ala. Code $\$ 11-54 B-19$ (1994); D.C. Code Ann. $\$ 1-2288$ (Supp. 1998); Ga. Code Ann. § 36-43-9 (1993 \& Supp. 1998); Miss. Code Ann. § 21-43-131 (Supp. 1998); N.M. Stat. Ann. § 3-63-15 (Michie 1995).

125. See Mont. Code Ann. § 7-12-1141 (1997); Okla. Stat. Ann. tit. 11, § 39-103.1(D)

(West \& Supp. 1999); W. Va. Code § 8-13A-15(b) (1998).

126. See Del. Code Ann. tit. 22, § 1503 (1997). 
and opportunity for protest-applicable to BID formation. ${ }^{127}$ Some jurisdictions employ looser criteria for renewal than for original creation. ${ }^{128}$ In other states, the BID enabling legislation does not limit the district's life but, instead, restricts the period of the BID assessment to one year, ${ }^{129}$ four years, ${ }^{130}$ or five years. ${ }^{131}$ Subsequent assessment would require new municipal action.

Most of the states that do not limit the duration of their BIDs authorize either the assessment payers or the municipal government, or both, to dissolve the BID. Some substantial fraction-usually a majority or supermajority - of district property owners or businesses, measured in terms of assessed valuation, area, or number of owners, can petition for the dissolution of the BID. ${ }^{132}$ Unlike the formation process, the city typically has little discretion in the matter if the number of signatures on the dissolution petition crosses the statutory threshold. Similarly, a number of states expressly authorize the city government to dissolve the BID even in the absence of property owner or business petitions, and without having to obtain the approval of the property owners or businesses in the BID. ${ }^{133}$ The municipal power to disband a BID can be limited if the BID has issued long-term debt; ${ }^{134}$ however, many states do not authorize BIDs to issue debt, and even in states that permit it, the city may have discretion to determine in the ordinance creating the BID whether a particular BID has power to incur debt.

There is less experience with BID termination than formation. Most BIDs are relatively young and few have been terminated at the end of

127. See, e.g., Ga. Code Ann. § 36-43-9 (Supp. 1998); Miss. Code Ann. § 21-43-131 (Supp. 1998); Okla. Stat. Ann. tit. 11, § 39-103.1(d) (West Supp. 1999); W. Va. Code § 813A-15(b) (1998).

128. See, e.g., D.C. Code Ann. § 1-2288 (Supp. 1998).

129. See Cal. Sts. \& High. Code $\S 36534$ (a) (West Supp. 1999); N.J. Stat. Ann. $\S \S 40: 56-81,40: 56-84$ (West 1992).

130. See Ohio Rev. Code Ann. $\S 1710.02$ (F) (West 1994 \& Supp. 1998).

131. See, e.g., Cal. Sts. \& High. Code $\S 36622$ (West Supp. 1998); Ky. Rev. Stat. Ann. $\S 91.754$ (1) (Michie Supp. 1996); Or. Rev. Stat. § 223.117(1)(d) (1997).

132. See Ala. Code $\S 11-54 B-19$ (1994); Ark. Code Ann. § 14-184-130 (Michie 1998); Cal. Sts. \& High. Code $\S 36650$ (West Supp. 1998); Colo. Rev. Stat. Ann. § 31-25-1225 (West Supp. 1998); D.C. Code Ann. § 1-2288(b) (Supp. 1998); Idaho Code §50-2618 (1994); Kan. Stat. Ann. § 12-1789 (1991); Ky. Rev. Stat. Ann. § 91.762(2)-(3) (Michie Supp. 1996); Mass. Ann. Laws ch. 40O, $\S 10$ (Law. Co-op. Supp. 1998); Miss. Code Ann. $\S 21-43-133$ (Supp. 1998); N.Y. Gen. Mun. Law § 980-n (McKinney Supp. 1998); Ohio Rev. Code Ann. $§ 1710.13$ (West 1994 \& Supp. 1998); Tenn. Code Ann. § 7-84-529 (1998); Wis. Stat. Ann. § 66.608(4m) (West 1990).

133. See, e.g., Conn. Gen. Stat. Ann. § 7-339s (West 1989); Idaho Code $\S 50-2618$ (1994); Neb. Rev. Stat. § 19-4035 (1997); N.Y. Gen. Mun. Law § 980-n (McKinney Supp. 1998); Okla. Stat. Ann. tit. 11, § 39-103.1(d) (West 1994 \& Supp. 1999); S.D. Codified Laws § 9-55-19 (1995); Utah Code Ann. § 17A-3-413 (1991); Wash. Rev. Code Ann. § 35.87A.180 (West 1990); W. Va. Code $\S 8-13 A-15$ (a) (1998). A number of these statutes provide that the municipality may act only after notice and a hearing.

134. If a BID issues debt, the only way the municipality could terminate the BID while the debt is outstanding is to assume the debt itself. 
their statutory period or otherwise dissolved. ${ }^{135}$ The limited record suggests that BIDs may be terminated because of district-level opposition to BID assessments or as a result of dissatisfaction at city hall, ${ }^{136}$ but there are too few reported discussions of BID terminations to permit any confident generalization.

\section{B. Finances}

BIDs are financed primarily by assessments or charges imposed on property or businesses in the district. ${ }^{137}$ These charges are in addition to normally applicable state and local taxes. The BID, thus, differs from other sublocal urban development structures, like the enterprise zone, empowerment zone, or tax increment finance district, which rely on tax breaks in the district, the infusion of other government money into the district, or the reservation of revenues produced by existing taxes for financing programs in a district. ${ }^{138}$ Frequently, but not always, only commercial and industrial property is assessed. ${ }^{339}$ The rules, however, vary considerably from state to state, and some states authorize assessments

135. The most prominent instance involves the dissolution of the Lincoln Road BID in Miami Beach, Florida, see Houstoun, ULI, supra note 3, at 174. In addition, in 1998, New York City terminated the Grand Central Partnership's contract to manage the Grand Central BID, see Thomas J. Lueck, Business Improvement District at Grand Central Is Dissolved, N.Y. Times, July 30,1998 , at B1.

136. City Hall may promote district-level opposition by promising property owners it can provide the additional services out of ordinary taxes without need of a BID assessment. See Houstoun, ULI, supra note 3, at 174 .

137. In most states, the additional taxes are special assessments against property in the district, which are paid by the property's owner. These assessments may be based on valuation, front footage, square footage, property tax payment, precise location within the district, the use to which the property is put, or a combination of methods. See, e.g., Ala. Code $\S 11-54$ B-8 (1994); Ark. Code Ann. § 14-184-118 (Michie 1998); Colo. Rev. Stat. Ann. $\S 31-25-1219$ (West 1990 \& Supp. 1998); N.J. Stat. Ann. § 40:56-72 (West 1992); N.Y. Gen. Mun. Law $\S 980-\mathrm{j}$ (McKinney Supp. 1998). Due to a special provision of the Illinois Constitution, Illinois Special Service Areas may be financed by increases in the property tax rather than special assessments. See Illinois Dep't of Commerce and Community Affairs, Office of Urban Assistance, Special Service Area Financing 2, 6 (1988).

Several states provide for BIDs that are financed out of surcharges on business taxes, such as the business license fee, or occupation tax. Some states offer the option of both property tax and business tax BIDs. See, e.g., Ga. Code Ann. § 36-43-6 (1993); Neb. Rev. Stat. § 19-4018 (1997); N.J. Stat. Ann. § 40:56-85 (West 1992); S.D. Codified Laws § 9-55-2 (Michie 1995).

138. See Briffault, Sublocal Structures, supra note 53, at 509-11 (enterprise and empowerment zones), 512-14 (tax increment finance districts).

139. See, e.g., Cal. Sts. \& High. Code $§ 36634$ (b) (West Supp. 1999) (exempting agricultural and residential property); Or. Rev. Stat. § 223.114(2)(c) (1997) (same); Wis. Stat. $\$ 66.608(5)$ (a) (West 1990) (exempting residential property). Some states exempt only single-family owner-occupied housing, or only property zoned residential, thus permitting assessments of property zoned commercial that is in residential use. Others do not mandate exemptions but permit municipalities to exempt residential or other noncommercial property. See, e.g., N.J. Stat. Ann. § 40:56-66b (West 1992); Tex. Loc. Gov't Code Ann. § 375.164 (West Supp. 1999); Wis. Stat. Ann. §66.608(1)(f)(1m) (West 1990). 
against residential or other types of noncommercial property, although usually at rates lower than that applied to commercial property. ${ }^{140}$ Due to its reliance on district charges, a BID is generally viewed as "self-supported" 141 or "self-financing," 142 and as avoiding "further demand on the strained public treasury." 143

BID assessments are generally small compared to property taxes. Assessments appear to run under-often well under-ten percent of local property taxes, or under one percent of assessed valuation. In some states the level of assessment is capped by the BID enabling law; ${ }^{144}$ in most states assessments are effectively capped by the need to win the support of those who have to pay the assessments in order to get the BID created in the first place. Thus, although New York law permits a BID's assessment to run as high as twenty percent of the city property taxes collected in the district, ${ }^{145}$ assessments in two of the city's largest BIDs amount to about two percent of property tax payments. Assessments in Philadelphia's Center City District-one of the largest BIDs in the country-are six percent of property taxes. ${ }^{146}$ A 1990 study of six New Jersey BIDs found that their surcharges ranged between $2 \%$ and $8.7 \%$ of existing taxes. ${ }^{147}$ The assessment in Pittsburgh's downtown BID is $4.25 \%$ of local property taxes. ${ }^{148}$ According to a 1995 study, the assessment in Dallas's downtown BID was 1.7\% of total property taxes paid in 1992, and was projected to rise to $3.0 \%$ in 1996.149 The highest assessment rate for the downtown Denver BID was fifty-seven cents per one hundred dollars of assessed valuation; in Portland, Oregon, the rate was thirty-four cents per one hundred dollars of assessed valuation. ${ }^{150}$ A survey of twentythree BIDs across the country, conducted by the Pittsburgh Downtown Partnership in 1995, found that assessments generally ranged from six to

140. In New York City, the Department of Business Services recommends that fully residential properties be assessed at the nominal rate of one dollar per year. See DBS Guide, supra note 86, at 11 .

141. Iowa Code Ann. $\S 386.1$ (West 1976 \& Supp. 1998).

142. E.g., N.J. Stat. Ann. $§ 40: 56-65$ (West 1992).

143. Del. Code Ann. tit. 22, § 1501(4) (1997).

144. See, e.g., Idaho Code $\S 50-1703 \mathrm{~A}(6)$ (1994) (no parcel may be assessed more than $20 \%$ of its market value); Mass. Ann. Laws ch. $40 \mathrm{O}, \S 7$ (Law. Co-op Supp. 1998) (total assessments may not exceed one-half of one percent of the assessed valuation of property owned by participating members in the district); Mo. Ann. Stat. $\S 71.800$ (West 1998); Or. Rev. Stat. $§ 223.114$ (2) (a) (1997) (assessments capped at one percent of real market value of real property in district).

145. See N.Y. Gen. Mun. Law $§ 980-k$ (b) (McKinney Supp. 1998).

146. See Center City District Philadelphia's Business Improvement District (last modified Feb. 18, 1999) <http://www.centercityphila.org./ccdinfo.html > [hereinafter Center City BID] (on file with the Columbia Law Review).

147. See IDA, supra note 10, at 24.

148. See Kari Hudson, Special District Governments: Examining the Questions of Control, Am. City \& County, Sept. 1996, at 66.

149. See Downtown Improvement District, supra note 2, at 14 .

150. See IDA, supra note 10 , at 42 . 
eight cents per square foot. ${ }^{151}$ Another recent study found that BID assessments were typically ten to twelve cents per square foot. ${ }^{152}$

With property ownership in some downtowns concentrated in relatively few hands, a small number of big landowners may pay a significant fraction of a BID's bills. ${ }^{153}$ The Pittsburgh Downtown Partnership found that, in the twenty-three BIDs surveyed, the ten largest properties in a district on average accounted for forty-two percent of the district's assessments. ${ }^{154}$ Another study found that in Philadelphia, fifteen propertiesout of more than two thousand subject to assessment-accounted for thirty-seven percent of the Center City District's assessments, and the top two hundred properties paid eighty-seven percent of the assessments. ${ }^{155}$ Conversely, owners of smaller, or lower valued properties, pay much smaller assessments. In 1994, the average annual assessment of the sixteen BIDs that responded to this question in the Pittsburgh Downtown Partnership survey was $\$ 4,729^{156}$ —and the Pittsburgh survey focused on relatively large BIDs. In other BIDs, annual assessments, particularly those paid by smaller landowners, are likely to be just a few hundred dollars. ${ }^{157}$

District assessments are the primary, but not the sole, source of BID funds. One analyst, writing in 1992, determined that assessments accounted for about seventy percent of BID revenues. ${ }^{158}$ The Pittsburgh survey determined that property owner assessments provided eighty-four percent of the budget for the responding BIDs; for eight BIDs, assessments were the sole source of funds, and five other BIDs received more than ninety percent of funds from assessments. ${ }^{159}$ Many districts are

151. See Hudson, supra note 148 , at 66 .

152. See Houstoun, BIDs, supra note 1 , at 8 .

153. See Houstoun, Betting, supra note 2, at 16 .

154. See Hudson, supra note 148 , at 71 .

155. See Houstoun, BIDs, supra note 1 , at 8 . The largest assessment paid in Philadelphia was over $\$ 300,000$. See id. Perhaps the largest single assessment paid by any property owned is the half million dollar charge imposed on the Empire State Building, located in New York's 34th Street BID. See MacDonald, supra note 13, at 40.

156. Pittsburgh Downtown Partnership, Survey of Business Improvement Districts 5 (1995). The median assessment in the nine BIDs that responded to this question was $\$ 16,234$. See id.

157. The Project for Public Spaces study conducted for the International Downtown Association in 1991 estimated that "a dollar a day is a reasonable amount for small retailers to pay during the initial start up." PPS, supra note 11, at 27.

158. See Pack, supra note 5, at 20.

159. See Pittsburgh Downtown Partnership, supra note 156, at 4. See also NY COM, supra note 2, at 6, 12, 16-20 (special assessments sole source of revenues for BIDs in Downtown Elmira, Downtown Albany, Cedarhurst, Great Neck, Patchogue, Peekskill, and Greater Port Washington). The PDP survey almost surely undercounts the percentage of BID revenues that come from assessments since it states that New York's Grand Central BID had a 1994 budget of $\$ 130$ million, with assessments providing $\$ 8$ million. The $\$ 130$ million is far greater than all other accounts of the Grand Central budget, which place the figure at about $\$ 14$ million. See Bureau of Management Audit, The City of New York Office of the Comptroller, Audit Report on the Internal Controls and Operating Practices 
funded entirely by assessments, but others receive funds from other sources, including voluntary payments from tax-exempt property owners, proceeds of bonds backed by district revenues, interest income, and funds generated by charges for district operations, such as the management of district-owned facilities ${ }^{160}$ or the sale of district services. ${ }^{161}$ BIDs may also receive public funds, including federal or state economic development grants, ${ }^{162}$ payments from governments owning property in the district, ${ }^{163}$ revenues generated from managing publicly owned facilities, ${ }^{164}$ or appropriations from city or county treasuries. ${ }^{165}$ Overall, probably less than ten percent of BID revenues comes from general government funds, ${ }^{166}$ but for some BIDs the percentage may be far greater. ${ }^{167}$

In addition to occasionally providing municipal treasury funds, city governments play three important roles in financing BIDs. First, most BIDs rely on the municipal tax collection system to obtain their assess-

of the Grand Central Partnership Business Improvement District ES-2 (1997) [hereinafter Comptroller's Audit]. The PDP study may incorporate Grand Central's debt-based capital program, although that is far less than $\$ 130$ million. Aside from Grand Central, assessments amounted to more than $80 \%$ of BID budgets in 16 cases out of 22 observations, and between $50 \%$ and $79 \%$ in three more cases.

160. See NY COM, supra note 2, at 6 (more than one-third of the revenues of the Corning Intown BID in Corning, New York comes from the management of a parking garage).

161. This may include sales of services to firms or property owners outside the BID. See, e.g., Houstoun, BIDs, supra note 1, at 5-6.

162. See Idaho Falls Post-Register, Dec. 11, 1996 (Idaho BIDs created to receive CDBG and TIF funds).

163. See General Services Administration News Release, GSA Creates Good Neighbor Program: A New Partnership with America's Cities, Sept. 30, 1996, at 1 [hereinafter GSA] (GSA to contract for security, maintenance, cleaning and other services from BIDs); Jean Van Valkenburgh, Feds to Help Mall Maintenance, Memphis Com. Appeal, Dec. 18, 1996, at $8 \mathrm{~B}$ (GSA to contribute $\$ 21,000$ to Center City Commission for maintenance of Main Street Mall in Memphis's Central Business Improvement District).

164. See IDA, supra note 10 , at 42 (approximately $40 \%$ of the revenue of the Portland, Oregon downtown BID comes from the management of seven city garages).

165. See, e.g., Elliott v. Morgan, 571 N.W.2d 866, 867 (Wis. 1997) (Milwaukee BID received $\$ 8.5$ million from the city in addition to $\$ 1.945$ million in special assessments); Jody Callahan, Yet Another Plan Offered for Central Business Area, Memphis Com. Appeal, Nov. 28, 1996, at 10EC (Memphis BID receives $\$ 250,000$ apiece from city and county); Ernst-Ulrich Franzen, Opel OK'd Loan to Cover BID Deficit; Officials Disagree Over Whether District Knew of Revenue Shortfall, Milwaukee J.-Sentinel, Dec. 11, 1996, at 1 (city provided $\$ 26,000$ out of BID's $\$ 137,000$ in revenues and then provided additional $\$ 15,000$ to cover budget deficit); Mark Glover, Businesses on Fulton Rev Up for Self-Help, Sacramento Bee, Apr. 1, 1998, at C1 (Sacramento county funds will match BID assessment funds).

166. See Pack, supra note 5, at 20.

167. See, e.g., Elliott, 571 N.W.2d at 867 (large city grant to a BID to fund Riverwalk construction project); Glover, supra note 165 , at $\mathrm{C} 1$. As previously noted, governments may provide BID sponsors with "seed money" during the BID formation process, although this may have to be repaid from assessments once the BID is established. 
ments. The municipality, not the BID, typically bills the owners or businesses subject to assessment and gathers the payments. ${ }^{168}$

Second, municipalities usually have some formal control over BID finances. Generally, the assessment mechanism, including the formula applied to particular parcels or firms, must be approved by the municipal government when a BID is created. Subsequent changes in the formula or increases in the rate require municipal approval as well. Municipalities may have considerable authority over whether the BID may issue bonds. Many states permit BIDs to issue bonded debt; some prohibit it. But, as with assessments, a particular BID's authority to issue debt can be restricted by the city ordinance creating the BID. It is not clear how closely cities review BID requests to increase assessments ${ }^{169}$ or issue bonds, but, as the decision by New York City's Mayor to bar the further issuance of bonded debt by the city's BIDs demonstrates, ${ }^{170}$ when a city blocks new debt or refuses approval of an assessment increase, a BID has little legal recourse but to accept the municipal decision. ${ }^{171}$

Third, BID assessments and charges are, for many legal purposes, treated like taxes. Failure to pay a BID assessment may subject a property owner to the same penalties, including fines, the filing of a lien, and delinquency sale, as apply to nonpayment of property taxes. ${ }^{172}$

More generally, despite the rhetoric of BIDs as voluntary associations, BID assessments are like taxes in that, in nearly every state, ${ }^{173}$ they

168. See, e.g., Va. Code Ann. $\S \S 15.1-18.2-6$ (Michie 1997) (authorizing city to "levy and collect an annual tax upon any property in [a special] service district subject to local taxation"; "the proceeds from such annual tax shall be so segregated as to enable the same to be expended in the district in which raised"). Some states require BIDs to do their own assessing and collecting. This can put a financial burden on smaller BIDs. See Houstoun, ULI, supra note 3 , at 36-37. Philadelphia's Center City BID is the principal large BID with the power to collect its own assessments.

169. A BID may reduce municipal oversight by relying on an assessment formula, such as one based on assessed valuation, that yields increased payments as property values rise.

170. See Clifford J. Levy, City Prohibits Borrowing by Improvement Districts, N.Y. Times, Sept. 14, 1996, at B22.

171. See Philip Lentz, Giuliani's Tentacles Pinch BID, Crain's N.Y. Bus., Apr. 27, 1998, at 1 (reporting that New York City's Mayor is refusing to approve a requested $3.9 \%$ budget increase for the Grand Central BID).

172. See, e.g., Cal. Sts. \& High. Code $§ 36632$ (West 1969 \& Supp. 1999); Ky. Rev. Stat. $\S 91.758(5)$ (Michie 1982 \& Supp. 1996); ODDA, supra note 97, at 17. New York goes even further and treats BID assessments as taxes for purposes of state constitutional tax limitations-although in most states BID assessments, like special assessments generally, are not taxes subject to state constitutional ceilings. See N.Y. Gen. Mun. Law § 980-k(b) (McKinney Supp. 1999).

173. Massachusetts is the only state that enables property owners in a BID to opt out of the duty to pay assessments. See Mass. Ann. Law ch. 40O., $\S 4$ (Law Co-op. 1998). This has proven a significant obstacle to the creation of BIDs in the state. See Richard Kindleberger, Focus Downtown: Property Owners, City Study Taxing Businesses to Make Downtown Boston Safer and Cleaner, Boston Globe, Apr. 6, 1997, at F1. In the summer of 1998, Springfield became the first city to create a BID with an opt-out provision. See Greg Gatlin, Springfield Makes First Bid, Boston Herald, Aug. 26, 1998, at 39. According to one report, owners of $94 \%$ of the district's 272 properties agreed to participate in the BID. See 
are compulsory for all property owners or businesses in the district who are subject to assessment-even for those who filed a written protest against the creation of the BID. The compulsory nature of BID assessments is what attracts downtown commercial associations, chambers of commerce, and other organized business interests to the BID device. The BID assessment frees them of the "ongoing, arduous, complex and often times very personal" 174 burden of securing contributions, provides a stable and secure funding base for downtown programs, ${ }^{175}$ and eliminates the ability of nonpaying businesses to free-ride on the contributions of others. ${ }^{176}$ The coercive assessment is essential to the BID.

\section{Functions}

BID activities may be grouped into four broad categories, recognizing that some activities may fall into more than one category, while others may not easily fit into any category. These categories are: physical improvements, traditional municipal services, social services, and businessoriented programs. ${ }^{177}$

1. Physical Improvements. - Many BIDs repair or renovate streets, sidewalks and public places, and provide new public amenities. They pay for repaving, relighting, new signage, landscaping, planters, flowers, trees, informational kiosks, bus shelters, benches, lamp stanchions, hydrants, and other so-called street furniture. New York's Bryant Park BID became famous for its successful reconstruction of that once troubled park. New York's 34th Street BID has committed \$2 million to transform

Davis Bushnell, Springfield Strengthens its Business District, Boston Globe, Nov. 21, 1998, at G1. Boston is currently attempting to create a BID for its Downtown Crossing shopping area, but that proposal involves an effort to outflank the opt-out law through the enactment of special state legislation for the Downtown Crossing BID. Under Mayor Menino's proposal, the BID would also require the approvals of property owners representing $51 \%$ of total district valuation and of $75 \%$ of property owners. See Gatlin, supra. The Boston City Council approved the proposal in December 1998. See Anthony Flint, Downtown Crossing Plan Ok'd by Council, Boston Globe, Dec. 10, 1998, at A48.

174. PPS, supra note 11 , at 7 .

175. See, e.g., New Jersey Dep't of Community Affairs, Business Improvement Districts Information Guide 3 (1996); ODDA, supra note 97, at 2.

176. See, e.g., PDC, supra note 69, at 13 ("This option [Business District Authorities] was chosen . . . on the basis that a BDA would guarantee revenue and eliminate 'freeriders.' "); Dale Bryant, Downtown Association Board Votes to Continue, Los Gatos Wkly.Times, Feb. 21, 1996, at 7 (BID sought in order to compel fast food businesses to contribute to downtown association's street cleaning program: “The only way we'll get them to do their part in keeping the sidewalks clean is to assess them."); Hannes Zacharias, Help Yourself With Downtown District, 7 Kans. Bus. News 39 (April 1986) ("Volunteer merchants associations ... provide opportunity for freeloaders to reap the benefits of organized promotions and professional management").

177. The principal activities that do not fit easily within this typology relate to transportation. BIDs manage parking facilities, operate shuttle buses to move people in and through pedestrian malls, and engage in transportation planning. See, e.g., NY COM, supra note 2, at 2, 37; Pittsburgh Downtown Partnership, supra note 156, at 6; Bradley, supra note 1, at 12; Houstoun, Betting, supra note 2, at 14 . 
two traffic islands into parks. ${ }^{178}$ BIDs in other cities have devoted funds to parking garages, pedestrian malls, and physical improvements to ease transportation access to older downtowns. ${ }^{179}$

Two themes run through many BID capital improvement programs. First, by repairing or replacing rutted streets, crumbling pavements, dying trees, and vandalized lampposts and benches, BIDs eliminate dangers and eyesores and improve the appearance, safety, and convenience of downtown areas for businesses, residents, and visitors alike. Second, BIDs may seek to place a distinctive stamp on the appearance of the public spaces, facilities, and properties in the district. This may involve the repeated use of certain materials-such as the "red granite signature corners" planned in Grand Central's capital program-or of design elements in lighting, benches, banners, and informational kiosks, and the placement of the BID logo on street lamps, street signs, newsstands, and street furniture. The goal is the creation of a distinctive district image that will help market the district to the outside world-as well as demonstrate the accomplishments of the BID to assessment payers within the district.

Many BIDs spend substantial sums on capital programs. Philadelphia's Center City District has undertaken a $\$ 21$ million bondfinanced plan of "streetscape improvements." New York's Grand Central BID issued $\$ 32$ million in bonds, and the affiliated 34th Street BID another $\$ 24$ million in bonds, to finance comparable programs. Overall, however, physical improvements are a relatively small part of most BIDs' activities. A 1994 study of five major BIDs outside New York City determined that only twelve percent of their expenses went for capital projects and streetscape improvements; a 1993 survey of New York City's eight largest BIDs found that just sixteen percent of their budgets went for these purposes. ${ }^{180}$ Special purpose districts and special assessment districts tend to focus on capital improvements, but the distinctive characteristic of the BID is its extensive involvement in municipal operating activities rather than capital projects-in providing services rather than undertaking new construction.

2. Traditional Municipal Services. - The central purpose of most BIDs is the supplementation of municipal sanitation, public security, and street maintenance. A New York City Council survey of the thirty-three BIDs

178. See Douglas Martin, The Greening of Herald and Greeley Squares (They'll Become Parks), N.Y. Times, Nov. 30, 1996, at B31.

179. Indeed, in a number of states, a BID may be formally named a "parking and business improvement" district, see, e.g., Cal. Sts. \& High. Code $\$ \S 36500-36551$ (West 1999), Wash. Rev. Code. Ann. $§ 35.87 \mathrm{~A}$ (West 1999) ("parking and business improvement areas"), or may be created pursuant to legislation initially intended to promote pedestrian malls, see N.J. Stat. Ann. § 40:56-65 (West 1992).

180. Houstoun, Betting, supra note 2, at 13 fig.1. The new Washington, D.C. downtown BID will spend $15 \%$ of its $\$ 7.7$ million annual budget on physical improvements. See Stephen C. Fehr, Property Owners Commit to Revive D.C.: In Heart of District, A $\$ 38.5$ Million Push for Safety, Cleanliness, Wash. Post, July 27, 1997, at A1. 
operating in the city in 1995 determined that ninety-four percent provided sanitation service, seventy-nine percent engaged in street maintenance, and seventy-six percent provided some form of public security. ${ }^{181}$ Sanitation accounted for twenty percent, and security twenty-five percent, of BID spending. ${ }^{182}$ An earlier study of the city's eight largest BIDs found that fifty percent of expenditures went for traditional municipal services; a study of five other big city BIDs also found that half of BID funds were spent on sanitation, street maintenance, and security. ${ }^{183}$

BIDs sweep and wash sidewalks and curbs, clear snow, ${ }^{184}$ pick up litter, empty trash receptacles, and remove graffiti. In Philadelphia, where, in the late 1980s, "[u]biquitous litter became a public obsession" 185 and "a daily assault on the city's spirit," 186 the Center City District deployed cleaners to vacuum and sweep sidewalks three times a day, power wash them once a month, and remove graffiti five days a week. ${ }^{187}$ New York City's Madison Avenue BID's "gleam team" cleans and paints lampposts, fire hydrants, and mail boxes and removes graffiti and stickers from street furniture.

In some BIDs, sanitation and maintenance efforts are tied to district promotion, with street cleaning crews dressed in distinctive uniforms that showcase the BID's efforts. New York's Grand Central BID refers to the " 60 white-suited sanitation workers" who sweep district streets and empty litter baskets as the "BID's most prominent ambassadors." 188 The Times Square BID makes the point of dressing its fifty-person sanitation crew in "bright cherry-red jumpsuits" and equipping them with red barrels and purple trashbags. BID critics generally acknowledge that BIDs have sig-

181. See Council of the City of New York, Staff Report to the Fin. Comm., Cities Within Cities: Business Improvement Districts and the Emergence of the Micropolis 77-78 (1995) [hereinafter Cities Within Cities].

182. See id. at $78,81$.

183. See Houstoun, Betting, supra note 2, at 13 fig.1. The Pittsburgh Downtown Partnership collected spending data from 23 BIDs. In 1994, 18 BIDs reported spending $\$ 10.1$ million-about one-third of the $\$ 31$ million in assessments collected-on cleaning activities. A slightly different set of 17 BIDs reported spending $\$ 7.7$ million on security. That accounted for more than a quarter of the $\$ 29.2$ million in assessments collected by these BIDs. See Pittsburgh Downtown Partnership, supra note 156, at 5. More recently, the new Washington, D.C. downtown BID has announced that it will devote $48.5 \%$ of its budget to such traditional municipal services as public safety, street cleaning, and street maintenance. See Fehr, supra note 180 , at A1. At a talk at the annual meeting of the International Downtown Association in New York City in September 1997, Paul Levy, the executive director of Philadelphia's Center City District, stated that $68 \%$ of his BID's budget was spent on cleaning and public safety.

184. In many jurisdictions, sweeping sidewalks and clearing snow are the responsibilities of the adjacent property owners, so that BIDs performing these functions are technically not providing a municipal function.

185. Dale Russakoff, Businesses Take On City Hall's Dirty Work: Private Interests Pick

Up Slack as Public Services Dwindle, Wash. Post, Sept. 19, 1991, at A1.

186. Id. (quoting an unidentified 1989 Philadelphia Inquirer editorial).

187. Center City District, supra note 2, at 15.

188. NY COM, supra note 2 , at 40. 
nificantly improved the cleanliness of the streets in the areas in which they operate; ${ }^{189}$ the distinctive uniforms and equipment ensure that the BIDs get the credit.

BID security efforts are more varied and more controversial. ${ }^{190}$ Some provide funds to city governments to pay for additional police officers, longer working hours, new equipment, and special police facilities. ${ }^{191}$ Philadelphia's Center City District, for example, financed a new police substation for the downtown area. New York's Downtown-Lower Manhattan BID recently concluded an arrangement with the New York Police Department in which the BID would finance the $\$ 5$ million cost of a new substation for the Wall Street area if the New York Police Department would relocate to the new facility some police officers assigned to the precinct that covers Wall Street but stationed in a facility outside the financial district. ${ }^{192}$ The downtown Baltimore BID substantially financed the installation of video surveillance cameras in a sixteensquare-block area. ${ }^{193}$ The Dallas Downtown Improvement District provided the police department with a paddy wagon, an auxiliary vehicle, reflective tack for the mounted patrol, collar/radio microphones, and a mobile command unit. ${ }^{194}$ Some BIDs work to get police departments to give more attention to the kinds of low-level criminality-vandalism, graffiti, purse snatching, pickpocketing, illegal peddling, ticket scalping and three-card pocketing - that are typically the most serious crime problems in business districts. Some improve area lighting, establish alarm systems, and work with merchants on crime prevention and personal security techniques. ${ }^{195}$

189. See Feldmann, supra note 14 , at 18 .

190. See, e.g., Barr, supra note 9, at 404-06 (describing “outreach teams" employed by New York's Grand Central Partnership whose use of intimidation and/or physical violence in removing homeless people from the BID earned them the nickname "goon squads").

191. See, e.g., Downtown Denver Business Improvement District (undated brochure published by Downtown Denver BID listing 1995 BID board of directors, on file with the Columbia Law Review) (BID contributes to the city's Mounted Patrol and provides motorcycles, a police car, and other equipment).

192. See Michael Cooper, Mayor Defends Payment for a Police Base, N.Y. Times, Feb. 18, 1998, at B3. In addition to housing 40 police officers from the First Precinct, who patrol the Wall Street area, the new substation would also house 75 officers from the citywide Homeless Outreach Unit, who would be relocated from a facility in Brooklyn, and 25 officers from the citywide movie and television unit, who would be relocated from midtown. See id.

193. See Christian Parenti, Robocop's Dream: The New Policing: From the Military to Your Streets, Omniscient Surveillance, The Nation, Feb. 3, 1997, at 22, 23-24.

194. See Downtown Improvement District, supra note 2, at 2-3. See also Diane Kittower, Good Business Neighborhoods Get Better, Wash. Bus. J. 21, June 13, 1997, at 21 (Bethesda, Maryland BID donated bicycles to local police department).

195. See, e.g., NY COM, supra note 2 , at 30,35 . BIDs' focus on petty criminality is, of course, entirely consistent with the concern with "quality of life" offenses and the attention to "fixing broken windows" that has come to loom so large in contemporary urban policing. There may be little disagreement between BIDs and big city police departments 
Many BIDs provide their own security. During 1995, twenty-one New York City BIDs collectively fielded 363 private security officers. ${ }^{196}$ BID security officers are typically uniformed but unarmed. They carry cellular phones, two-way radios, or walkie-talkies; patrol their districts' streets; and serve as the "eyes and ears" of the police. ${ }^{197}$ They generally do not make arrests, but they may assist the police in making arrests, ${ }^{198}$ as well as assist victims, take witness statements, and make court appearances.

Some BIDs seek to meld their security efforts with the municipal police. In Times Square, the BID's forty officers are equipped with radios and linked to the police by dispatchers in the BID office. In Philadelphia, the downtown police and the BID's force hold joint roll calls each day in the BID-financed substation and coordinate deployment strategies. ${ }^{199}$ The Grand Central BID brought together in one storefront the security forces of the BID, the city police, the commuter rail station's police, and private security forces employed by an adjacent office building. ${ }^{200}$ In Baltimore, BID patrols now handle a significant fraction of non-priority calls that formerly went to the police, freeing up the police for serious activities. ${ }^{201}$ Other BIDs work with police in getting out information concerning breaking crimes, analyzing crime statistics, and detecting patterns of criminal activity in their districts. ${ }^{202}$

Like the cleaning crew, the security force may have a role in marketing the district. Many districts refer to their security staffs as "community service representatives," 203 public safety guides, hospitality officers or goodwill "ambassadors." 204 Their uniforms are likely to favor windbreakers or blazers, in tourist-friendly colors, rather than the paramilitary wear of private security forces. ${ }^{205}$ The Los Angeles Fashion District BID, for example, outfits "brightly dressed" foot and bicycle patrols and "pur-

concerning the importance of maintaining public order and going after petty offenders. Indeed, in their leading study, Kelling and Coles bracketed BID initiatives with police department and law enforcement actions as successful instances of "taking back the streets" and drew no distinctions between BID security programs and municipal order maintenance initiatives. See Kelling \& Coles, supra note 35, at 194-235 (1996).

196. See Cities Within Cities, supra note 181, at 81.

197. See Maryann Haggerty, In Philadelphia, Signs of Success: Center City Is Cleaner, Safer-and Tax District Program Has Won Converts, Wash. Post, July 27, 1997, at A20.

198. See, e.g., NY COM, supra note 2, at 44, 45 (34th Street BID, Times Square BID). According to Daniel Biederman, the manager of the Grand Central, 34th Street, and Bryant Park BIDs, "we allow the police to actually make the arrest, although we may hold someone for an arrest." Donna Greene, Westchester Q\&A: Daniel A. Biederman: The Greening of Downtown Districts, N.Y. Times, Sept. 21, 1997, $\$ 13$ (Westchester ed.), at 3.

199. See Center City BID, supra note 146.

200. See NY COM, supra note 2, at 40.

201. See Pike, supra note 56, at 22.

202. Id.

203. See, e.g., Center City District, supra note 2, at 17. See also Downtown Improvement District, supra note 2, at 2 ("Dallas Ambassadors").

204. Id.

205. James Krohe, Jr., Why Reform Government? Replace It, 29 Across the Board 40, 43 (1992). 
ple-clad customer service ambassadors" who circulate through the district. In Atlanta, the "ambassadors" are outfitted in white pith helmets, starched white shirts, blue pants and teal-colored jackets. ${ }^{206}$ These uniformed street personnel are trained to provide shoppers and tourists with directions, assistance and information concerning special events in the district, and to notice conditions in need of repair as well as to report crimes and discourage disorder. Consistent with the general focus of BID security efforts on maintaining order and deterring low-level crime, the goal of the uniformed BID patrols is to provide "visitors, residents, and workers with a heightened sense of security." ${ }^{207}$ The sense of security may contribute directly to real security if it leads to an increase in the number of visitors, residents, or workers in the area.

The traditional municipal services of cleaning, maintaining and patrolling city streets are the most important functions of most BIDs, in terms of budget, impact, and the public attention given to BIDs. Through the daily deployment of distinctively clad street cleaners and hospitality/security personnel, BIDs have become a part of the fabric of daily life in the neighborhoods in which they operate. Their apparent success in delivering traditional municipal services forms the basis of much of the praise BIDs have garnered. ${ }^{208}$

206. See Tom Barnes, User-Friendly Downtown Promoted: Golden Triangle Realty Levy Would Fund Patrolling Aides, Pittsburgh Post-Gazette, June 3, 1996, at A1 (a survey of downtown office workers in Atlanta found that teal was perceived as the "friendliest" color). See also Tom Barnes, Downtown Partnership Gets New Chief, Pittsburgh PostGazette, Aug. 7, 1997, at D4 (Pittsburgh's "ambassadors" wear gold shirts and black pants); Haggerty, supra note 197, at A20 ("teal shirts" on Philadelphia Center City District sidewalk sweepers). BID).

207. NY COM, supra note 2, at 37 (emphasis added) (Downtown-Lower Manhattan

208. There are few, if any, rigorous and independent reviews of BID services, or their impact on security, sanitation, and street maintenance in the districts in which these are provided. The commentary consists overwhelmingly of either anecdotal observations or studies undertaken by or for the BIDs themselves-often in conjunction with efforts to persuade a city council to continue a BID's existence, sell a proposed BID to landowners and firms, or showcase a district as a site for new investment. The BIDs eagerly tally the number of bags of trash they have collected, the number of "contacts" between their street "ambassadors" and tourists, and cite drops in local crime rates. See Downtown Improvement District, supra note 2, at 2. As one BID proponent has noted, "there is an inherent conflict between their roles as cheerleaders and their roles as measurers of economic and social conditions." Houstoun, BIDs, supra note 1 , at 9.

A rare independent review, undertaken by the staff of the Finance Committee of the New York City Council, focused not on the quality of BID services but on the satisfaction of property owners within districts, as determined by a telephone survey. The Council Report, however, is marred by its tendency to lump "don't know's" with "dissatisfied's" in reporting whether respondents were satisfied or dissatisfied with their BIDs, so that data indicating that $23 \%$ of respondents were dissatisfied with BID services is reported as $37 \%$ who were dissatisfied or unsure about the quality of BID services. See Cities Within Cities, supra note 181 , at $x v, 75$. Still, the study found that $81 \%$ of respondents reported their districts were cleaner, see id. at 78 , and more than $55 \%$ said they were safer, see id. at 81 . 
But BIDs' performance of traditional municipal functions, especially policing, has also been the source of many of the concerns about BIDs. BID security forces are seen as unaccountable and independent of the legal and political structures that serve to constrain the discretion of the public police. ${ }^{209}$ Similarly, BID-financed supplemental municipal services lead to charges that BIDs promote intralocal inequality. These charges are most heated when BID funds go toward enhancing the services provided by the municipality itself in the BID. The Wall Street police substation deal, which involved not the hiring of a BID security force but the redeployment of the city's police, provoked a public uproar, with mainstream critics alleging that the arrangement "sends the troubling message that wealthier communities can buy more police attention," 210 and others asserting that the "cash-for-cops deal" was tantamount to a bribe. ${ }^{211}$ On the other hand, a similar arrangement in Philadelphia seems to have caused little controversy. ${ }^{212}$

BID services are intended to "supplement and not supplant the municipal services of the municipality." ${ }^{113}$ In many states, the process of BID formation involves a determination of existing levels of municipal services provided within a district and a commitment by the municipality to maintain that baseline service level after the BID begins operations. ${ }^{214}$ In practice, it may be difficult to determine whether BID services affect the level of other municipal services even if a baseline services agreement is in place. ${ }^{215}$ Actual levels of services often depart from formal standards

209. See, e.g., Barr, supra note 9 , at 404-06. The relative autonomy of BID security forces may exacerbate the discretion problem endemic to so-called "quality of life" policing. For a comprehensive analysis of the discretion issues raised by the current ordermaintenance strategies of municipal police forces, see generally Debra Livingston, Police Discretion and the Quality of Life in Public Places: Courts, Communities and the New Policing, 97 Colum. L. Rev. 551 (1997).

210. Editorial, More Police on Wall Street, N.Y. Times, Feb. 19, 1998, at A18.

211. Jim Dwyer, Your Cop\$ on Wall Street, Daily News (N.Y.), Mar. 1, 1998, at 8.

212. Philadelphia's principal BID, the Center City District, financed the Center City District Operations Center. The Center serves both as the BID's headquarters and as a police substation for the officers and 70 foot-patrol officers assigned to the Center City. The BID's community service representatives-the BID's security force-"stand roll call and hold inspections alongside the police in the same room." Houstoun, ULI, supra note 3 , at 138 .

213. Tex. Loc. Gov't Code Ann. $§ 375.001$ (c) (West Supp. 1999) (municipal management districts). In New York, "[s]ervices for which district property owners are charged pursuant to the plan must be in addition to or an enhancement of those provided by the municipality prior to the establishment of the district.” N.Y. Gen. Mun. Law $\S 980-$ j(a) (McKinney Supp. 1999). Accord Ohio Rev. Code Ann. § 1710.08 (West Supp. 1998).

214. See, e.g., Ala. Code § 11-54B-4(g) (1994); D.C. Code Ann. § 1-2290 (Supp. 1998); Mont. Code Ann. § 7-12-1142 (1997); W. Va. Code Ann. § 8-13A-9(b) (1998).

215. In New York, some BID administrators claim that city sanitation services in their districts have been reduced because of BID services. The Council Report found that sanitation services had been reduced citywide but "it was impossible . . . to determine if services were reduced in greater percentages in BIDs." Cities Within Cities, supra note 181, at 79 . 
and criteria or reflect low-level decisions, and a municipal sanitation department may be able to stretch scarce resources by quietly cutting back on trash pickups or street cleaning in an area if it knows that a BID exists to pick up the slack.

On the other hand, some BID activities lead to additional municipal services beyond those actually paid for by the BID. Financing a new police substation in the district, providing the police with equipment for use in the district, or lobbying for greater law enforcement attention to district problems can result in the increased deployment of police personnel in the district above the level of additional security actually financed by the BID. This flypaper effect compounds the concern that BIDs cause wealth-based inequalities in service delivery. ${ }^{216}$

3. Social Services. - Few BIDs provide social services, and, for those that do, such services are usually a relatively small part of their programs. Some states authorize their BIDs to provide child care or employee training. ${ }^{217}$ Philadelphia's Center City BID, for example, provides an employment and training program for welfare recipients. The District has hired welfare recipients to work on a number of their physical improvement and street maintenance programs. Under a state welfare-to-work program, welfare grants are transferred to the BID, where they are matched by assessment funds, and used to pay welfare recipients' salaries. Some participants in the BID work program have ultimately been placed in fulltime jobs with the BID. ${ }^{218}$

The leading BID social service activity-in terms of both dollars and public controversy-involves the homeless. A number of BIDs in the downtown areas of larger cities have programs aimed at the homeless people who may be found in the streets, plazas, malls, bus and train terminals, and ATM vestibules in their districts. In New York, thirty percent of BIDs provide some social services, and five provide direct outreach services to the homeless. ${ }^{219}$ In 1993, social services amounted to twelve percent of the budgets of the larger New York BIDs. ${ }^{220}$

216. See Stark, supra note 22, at 75-76.

217. See, e.g., Ark. Code Ann. § 14-184-115(7) (Michie 1998) (child care); Miss. Code Ann. $\$ 21-43-105$ (d) (ix) (Supp. 1998) (training programs for employees); Tenn. Code Ann. § 7-84-520(10) (1998) (child care).

218. Paul Levy, executive director of the Center City District BID, explained the BID's employment and training program at a presentation at the Annual Meeting of the International Downtown Association in New York City, on September 21, 1997. The Center City District program pays the welfare recipients it hires minimum wage salaries. By contrast, a job training program for homeless individuals operated on behalf of New York City's Grand Central and 34th Street BIDs ran afoul of the federal Fair Labor Standards Act and New York State's minimum wage law when the BIDs paid the homeless workers only a subminimum training stipend rather than the minimum wage. See Archie v. Grand Cent. Partnership, Inc., 997 F. Supp. 504, 524-36 (S.D.N.Y. 1998).

219. See Cities Within Cities, supra note 181, at 85 .

220. See Houstoun, Betting, supra note 2, at 13 fig.1. The Washington, D.C. BID intends to devote $4.5 \%$ of its budget to homeless services. See Fehr, supra note 180, at A1. 
These programs may provide temporary shelter, food, employment, training, drop-in centers, or referrals to social service agencies. ${ }^{221}$ For many districts, however, programs dealing with the homeless grow out of the BID's goal of maintaining public order rather than a desire to provide social services per se. ${ }^{222}$ They aim to prevent panhandling and the sense of "social disturbance" attributable to the presence of the homeless. ${ }^{223}$ The Portland BID "sends out its security guards to give morning 'wake-up calls' to the homeless-in other words, to roust them from the doorways of businesses."224 Baltimore's "guides" press panhandlers to move along; "[i]f a panhandler refuses, the guides station themselves on either side of him and discourage pedestrians from giving money."225 With slightly more finesse, Philadelphia's Center City District sponsored a program to discourage pedestrians from giving money to panhandlers; potential donors were urged to give beggars cards referring them to social service agencies instead of loose change. ${ }^{226}$

Even where BID programs emphasize the provision of services to the homeless and outreach efforts to connect the homeless with social service programs, critics have alleged that homeless assistance can turn into homeless removal. New York's Grand Central BID became embroiled in a major public controversy in 1995, which ultimately resulted in the loss of a half-million-dollar federal grant and a restructuring of its social service programs, when several outreach workers employed by the BID claimed they operated as "goon squads" assaulting homeless individuals in order to remove them from ATM vestibules and other private areas. ${ }^{227}$ An independent investigation by Robert Hayes, a leading advocate for the homeless, found "no credible evidence" to support the claims that BID officials "purposely encouraged or condoned brutal or bullying conduct by outreach workers" and dismissed the "image of organized, roving 'goon squads' . . . beating and intimidating homeless people [as] fanciful." 228 Indeed, Hayes praised the Grand Central BID for operating a facility that provided a "remarkably safe and secure haven for homeless

221. See, e.g., Downtown Improvement District, supra note 2, at 3 (homeless assistance grants to social services agencies); PDC, supra note 69, at 20; Fehr, supra note 180 , at A1.

222. See, e.g., Downtown Improvement District, supra note 2, at 3 (reporting homeless assistance programs under the rubric of "[s]afety").

223. See, e.g., Bradley, supra note 1, at 11-12.

224. MacDonald, supra note 13 , at 40.

225. Id.

226. See Vernon Loeb, Giving Panhandlers a Different Handout, Phila. Inquirer, Dec. 10,1993 , at B1.

227. The homeless outreach services were technically provided by the Grand Central Social Services Corporation ("GCSSC"), rather than the BID itself. The GCSSC was an affiliate of the BID, and its board consisted entirely of members of the Grand Central BID's senior staff. See Robert M. Hayes, Report to the Board of Directors, Grand Central Partnership, on the Grand Central Partnership Social Services Corporation 14 (1995) [hereinafter Hayes Report].

228. Id. at 47. 
men and women" that was "safer and more humane" than municipallyoperated shelters. ${ }^{229}$ Nevertheless, Hayes found that the BID had failed to provide its outreach workers-who were formerly homeless individuals themselves-with proper levels of screening, training, and supervision, and he determined that, in combining the "separate missions of outreach and security," the BID's homeless outreach program was "flawed in its design." 230

Although the "goon squad" uproar was disconnected from the proven facts, the issue demonstrates, as the Hayes Report points out, the tension inherent in BID programs that seek to combine the traditional social service goals of homeless outreach with the security and business development goal of homeless removal. Given the business orientation of BID programs, and the private sector domination of BID managing boards, the goal of increasing the sense of security and order-including the elimination of the sense of danger and disorder that the presence of the homeless often creates-is likely to dominate the more charitable goals of providing material assistance, counseling, and appropriate referrals to social service agencies.

Yet, some BIDs do undertake programs that offer the homeless food, clothing, shelter, psychiatric and medical services, and substance abuse counseling. ${ }^{231}$ By separating the social service and security components of their programs, and by contracting with independent social service agencies rather than engaging directly in homeless outreach, the Times Square and Downtown-Lower Manhattan BIDs manage to provide homeless assistance-and also reduce the public presence of the homeless in their districts-without coercion or violence. Indeed, apart from its controversial outreach program, the Grand Central BID operated a multiservice drop-in center which, over a seven-year period, found full-time jobs for almost four hundred formerly homeless people, and permanent homes for almost six hundred. The New York City Council, which gave extensive attention to the Grand Central incident in its highly critical 1995 report on the City's BIDs, was "not prepared to recommend that BIDs discontinue providing such services" "[i]n view of the increasing budget cuts in homeless services at the Federal, State, and local

229. Id. at 52,54 .

230. Id. at 4. The publicity over the "goon squad" allegations led to investigations of Grand Central's social services which revealed there had been prior claims, resulting in lawsuits, of violence by BID outreach workers. See Cities Within Cities, supra note 181, at 86-93. The Grand Central BID's homeless program also drew sharp criticism for employing the homeless, rather than social service professionals, as outreach workers, and for paying them only a minimal "training stipend," rather than a wage. See David Stout, For Troubled Partnership, A History of Problems, N.Y. Times, Nov. 8, 1995, at B6. The failure to pay the minimum wage to the homeless people working in the BID's Pathway to Employment program was subsequently held to violate the federal Fair Labor Standards Act and New York State's minimum wage law. See Archie v. Grand Cent. Partnership, Inc., 997 F. Supp. 504, 524-36 (S.D.N.Y. 1998).

231. See Cities Within Cities, supra note 181, at 91-93. 
levels. ..."232 Although BIDs may not be the ideal providers of homeless services, the real problem may be, as the New York City Council acknowledged, that there are so few publicly-financed alternatives. Homeless advocate Hayes found that "the resources of BIDs and business associated with BIDs are vitally important to meet the needs of ... [the] homeless poor," and he concluded "there is absolutely no question that BIDs should remain involved in the provision of social services." 233

4. Business-Oriented Services. - In a sense, all BID services are business-oriented. The rehabilitation of public places, the enhanced cleaning and patrolling of streets and sidewalks, and the removal of the homeless by persuasion or coercion are all intended to improve the business environment, even if they also benefit the many people who live in or visit the district. Many BIDs go further and provide direct assistance to businesses, rather than simply making neighborhoods more attractive places for doing business. Increasingly, BID programs are focused on such "soft services"234_promoting the districts, marketing the products of district businesses, recruiting and retaining businesses, attracting tourists and consumers, and working with individual firms and local industries.

In New York City, ninety-four percent of BIDs offer some promotion and marketing services. ${ }^{235}$ In 1993, the City's eight largest BIDs allocated ten percent of their budgets to business-oriented services; in 1994, five major downtown BIDs in other cities spent fifteen percent of their funds on such services. ${ }^{236}$ Many of these business-oriented services resemble those offered by chambers of commerce, merchants' associations, and other downtown development organizations. BIDs may sponsor direct mail advertising, flyers, circulars, coupons, calendars of events, newsletters, cooperative promotion campaigns, discounts, and shopping guides that feature district stores; ${ }^{237}$ a directory of downtown stores; an infomercial promoting the district; ${ }^{238}$ billboards and kiosks that feature district events; downtown parking discounts; and a variety of special events and entertainment-such as lunchtime concerts, holiday lighting, summer evening shows, ${ }^{239}$ food festivals, and the Times Square BID's

232. Id. at 85 .

233. Hayes Report, supra note 227, at 2.

234. See Ward, supra note 88 , at J1.

235. See Cities Within Cities, supra note 181, at 83.

236. See Houstoun, Betting, supra note 2, at 13 (expenditures for public relations/ marketing, special events, retail promotions, facade and sign improvements, seasonal lighting, business attraction, and business retention). The Pittsburgh Downtown Partnership found that in 1994, 17 representative BIDs spent $\$ 3.2$ million, or about $13 \%$ of the $\$ 24.4$ million in assessments raised by these BIDs. See Pittsburgh Downtown Partnership, supra note 156, at 8-11.

237. See Cities Within Cities, supra note 181, at 83.

238. See Newport City Council Report, Orange County Register, Dec. 12, 1996, Newport Beach Ed., at 17.

239. See Marianne Flagg, Mixer Helps Restaurants Thrive After 5, Idaho Statesman, Sept. 7, 1996, at 1D. 
"Broadway on Broadway" and "First Night" programs on New Year's Eve. ${ }^{240}$

Some BID programs focus directly on particular businesses. New York's MetroTech Area BID launched an express bus service linking the BID in downtown Brooklyn to Staten Island-the home of two thousand of the sixteen thousand workers in the MetroTech Center which is the heart of the BID. ${ }^{241}$ New York's Fashion Center BID created an interactive kiosk, a website, and a central information resource center with computerized lists of the district's apparel industry resources, a calendar of events, and facilities for making showroom reservations, all "housed in an eye-catching octagonal structure adorned with the world's largest button appended to the structure's roof, held aloft by a 31-foot-long steel needle." ${ }^{42}$ New York's 34th Street BID provides management consulting services to the district's small retailers. ${ }^{243}$

Increasingly, BIDs engage in strategic planning for their districts. They will attempt to identify a distinctive niche or marketing theme, and tie special events, promotions or design improvements to that theme. ${ }^{244}$ Some BIDs may identify particular types of stores or categories of activities as targets for development. This may entail efforts "to recruit new businesses . . . to balance the business mix of the district."245 BIDs may provide office building owners with leasing assistance, ${ }^{246}$ work with owners of vacant buildings to find a buyer, ${ }^{247}$ or develop an appropriate financial package to attract an operator for a restaurant in an important location in the district. ${ }^{248}$ A few BIDs provide grants to businesses; ${ }^{249}$ the one in Milburn, New Jersey established a bank community development corporation to provide loans to district businesses. ${ }^{250}$ Strategic planning may even involve efforts to change the character of a district, such as the

240. See NY COM, supra note 2 , at 40,45 .

241. See Bill Farrell, S.I. to Metrotech Express, Daily News (N.Y.), Sept. 3, 1997, (suburban ed.), at 1 .

242. Sun Microsystems Unveils Multimedia Technology Center in New York City's Fashion District, Bus. Wire, Sept. 10, 1996.

243. See David M. Halbfinger, Free Retailing Advice, Indirectly From Macy's, N.Y. Times, Aug. 22, 1997, at B6.

244. See, e.g., Nesterak, supra note 2, at AA1 (New Jersey's BIDs are "searching for something unique" in their town's "history, geography or population to define its character and spark its renaissance"); Kittower, supra note 194, at 21 (signs established by Bethesda, Maryland BID "distinguish Bethesda from its surroundings, so you 'feel like you're in a special place'") (quoting Dee Metz, executive director of the Bethesda Urban Partnership).

245. N.J. Stat. Ann. § 40:56-83.b(14) (West 1992).

246. See Bradley, supra note 1 , at 11 .

247. See, e.g., Great Falls, Montana Business Improvement District, Goals 1995/1996 (on file with the Columbia Law Review).

248. See Mervyn Rothstein, Commercial Real Estate: Restaurant to Fill Niche Under Park Ave. Viaduct, N.Y. Times, May 14, 1997, at B6.

249. See Jerry Dean, Neighborhoods Focus of CBID's Interest, Knoxville NewsSentinel, Jan. 23, 1997, at C6.

250. See Bradley, supra note 1, at 11. 
efforts by a number of commercial or industrial downtowns to promote more residential uses. ${ }^{251}$

BID strategic planning often focuses on issues of appearance and design. In the belief that greater uniformity of design enhances the district's overall marketability, some districts attempt to promulgate design standards for private storefronts and buildings, and encourage local businesses and property owners to abide by the BID's architectural and aesthetic themes. ${ }^{252}$ A BID may attempt to persuade a store to tone down a too-garish sign, reduce the size of one that is out of scale with its neighbors, ${ }^{253}$ or urge another to replace solid metal grates with those in a less forbidding open-grille style. ${ }^{254}$ Several BIDs provide grants or loans for facade renovations; Philadelphia's Center City District, in cooperation with a local bank, introduced a special below-market rate loan to enable downtown firms to make storefront improvements, including gate replacements and treatments of store entrances, signage, display windows, and architectural detailing consistent with BID criteria. ${ }^{255}$

BID economic development strategy and design efforts need not involve the promotion of all business activity. Some districts may seek to discourage activity inconsistent with the plan or the image the BID is trying to develop. This can involve lobbying state and city governments for new laws or the enforcement of existing laws against street peddling or shops that sell pornography. ${ }^{256}$ New York's 34th Street BID trumpets the work of its "sign police" in successfully encouraging the city government to crack down on oversized signs that violate city laws and the BID's own

251. See Bob Brooke, Center City District Sees New Uses for Office Buildings, Phila. Bus. J., July 12, 1996, at 17 (describing program for converting upper floors of office buildings into apartments); Viki Reath, "A Small Price to Pay"; City Businesses Happy to Fund Extra Services, Wash. Times, April 3, 1997, at B8 (describing efforts of New York's Downtown-Lower Manhattan BID to develop tax abatements and incentives to "attract companies and developers wanting to convert older office buildings to residences").

252. See, e.g., Andrew Jacobs, From Kerouac to Kmart, N.Y. Times, Apr. 21, 1996, $\S 13$, at 4 .

253. See, e.g., Janet Allon, Union Square: Superstore Asked to Make Its Sign a Bit Less Super, N.Y. Times, Jan. 26, 1997, § 13, at 6.

254. See Mark Francis Cohen, Security Without the Scare: Mesh Gates Get Respect, Crain's N.Y. Bus., Sept. 22, 1997, at 28 (Brooklyn's MetroTech BID is offering to pay half the costs of business owners who replace solid gates with see-through mesh; according to BID director, mesh gates reduce the "impression of a siege mentality").

255. See Jessica Davis, Special Loan Rate Available for Downtown Retailers, Phila. Bus. J., Apr. 15, 1994, at 5; Thomas J. Walsh, Center City District Offers Facade Improvement Aid, Phila. Bus. J., June 6, 1997, at 6.

256. See Zukin, supra note 23, at 67, 275; Douglas Martin, Veterans Fighting for Right to Peddle in Midtown Once Again, N.Y. Times, June 6, 1995, at B3 (Fifth Avenue BID seeking to eliminate exemption for disabled war veterans from ban on peddling); Mark Schoofs, Beat It: The City's Moral Fixation: Pushing Porn Out Of Town, Village Voice, June 27, 1995, at 14 (efforts of Times Square BID to promote anti-porn shop zoning ordinance). 
standards of visual propriety. ${ }^{257}$ Other BIDs may attempt to influence landlords not to renew the leases of undesirable firms. ${ }^{258}$

Disagreements over economic strategy and district image have been the cause of conflict among businesses or land owners within BIDs. ${ }^{259}$ Where BID leaders see "visual anarchy," 260 congestion, unfair competition, filth, and noise, ${ }^{261}$ some firms may see a "carnival atmosphere" 262 attractive to their customers. More than a matter of mere aesthetics, these disputes concern which commercial activities, businesses, and customers ought to be attracted to, or discouraged from, the district, and thus can determine many of the social and economic factors that influence the character of the district. BIDs have little direct power over the business activities that go on within a district. But working with other city or state agencies and with private developers, BIDs can be part of broader efforts to recast the image and economic organization of a particular district, as exemplified by the remarkable transformation of Times Square from a so-called adult entertainment red light district to a combination family entertainment and office building center. Should BID efforts to shape the character of their districts expand, the level of conflict over BID development policies may grow as well.

BID efforts to shape the development of their districts rely on moral suasion; the provision of financial inducements, such as grants and loans; lobbying city hall; 263 or joining in lawsuits to enforce regulations or defend municipal ordinances that advance BID-initiated policies. ${ }^{264}$ BIDs

257. See Shop Talk: A Newsletter of the 34th Street Partnership, Inc., Spring 1997 (on file with the Columbia Law Review); see also Fehr, supra note 180, at A1 (Washington, D.C. downtown BID to seek greater enforcement of regulations governing poorly maintained buildings); Hollywood: City Ordinance to Target Stores' Signs, Banners, L.A. Times, July 1, 1997, at B4 [hereinafter Hollywood BID] (Hollywood Entertainment District BID working with city to enforce new ordinance regulating signs).

258. See Lawrence Sussman, Downtown Falls BID Could Be Model, Milwaukee J.Sentinel, Nov. 8, 1996, at 1 (BID persuaded a realtor to close down a Kentucky Fried Chicken franchise and replace it with a store more consonant with the district's plan).

259. See, e.g., Zukin, supra note 23, at 229 ("The conflicted identity of Fulton Street is fought out in the quality of goods in the shops, in the politics of the BID, and on the street itself.").

260. See Jacobs, supra note 252, at 4; see also Hollywood BID, supra note 257 (discussing BID enforcement of Hollywood ordinance against "visual clutter").

261. See Janet Allon, Navigating 125th Street, N.Y. Times, Feb. 4, 1996, § 13, at 4 (a principal goal of merchants in 125th Street BID is to get street vendors removed from the sidewalks).

262. Zukin, supra note 23 , at 67 .

263. See, e.g., Stringfellow's of New York, Ltd. v. City of New York, 653 N.Y.S.2d 801, 803 (N.Y. Sup. Ct. 1996) (Times Square BID allowed to intervene to defend city ordinance, which the BID had lobbied for, dispersing the concentration of so-called adult establishments). See also 34th Street BID Sues over Newstand, Real Est. Wkly., Feb. 24, 1993, at 5B (BID sues city to compel enforcement of municipal regulations against oversized, unlicensed newsstand).

264. See, e.g., Bery v. City of New York, 97 F.3d 689, 691 (2d Cir. 1996) (five BIDs filed amicus briefs in support of municipal ordinance prohibiting unlicensed street vending). See also City of New York v. State, 640 N.Y.S.2d 951 (N.Y. Sup. Ct. 1995) (BIDs 
are rarely, if ever, authorized to regulate the activities of district landowners, merchants, or residents directly. A few states, however, do contemplate a special role for BIDs in developing economic or building regulations for areas designated as BIDs. Georgia, for example, provides that, upon the creation of a BID, the governing authority of the municipality "may mandate design and rehabilitation standards for buildings within" such districts. ${ }^{265}$ In New Jersey, the ordinance authorizing the creation of a BID may require that construction or alteration of building and structure facades be subject to design criteria enforced by the body that manages the BID. ${ }^{266}$ New Jersey also authorizes special limitations on the activities of peddlers, pushcarts, and street vendors operating within BIDs. ${ }^{267}$

The rise of marketing, promotion, strategic planning, and direct assistance to businesses as central BID activities complicates the effort to situate BIDs along a public-private continuum. BID business-oriented services appear to present less of an issue of private encroachment on the public sector than does BID policing. Business-oriented services more closely resemble the activities of a chamber of commerce or trade association than those of a city government. The more BIDs shift their focus to business-oriented services, the less they present a threat of privatization. But BID strategic planning can significantly affect a district's economic activity and built environment. Moreover, in using assessment-provided funds to support efforts to shape the physical appearance, land uses, and path of development of their districts, BIDs are exercising the traditional public functions of planning, regulation, and spending tax dollars, even if these activities do not represent traditional public services, and even if BIDs lack the formal powers to unilaterally impose their plans.

BID-provided traditional municipal services tend to benefit the district as a whole-they are "public" within the boundaries of a district. BID business-oriented services are more likely to benefit discrete landowners or firms within the districts. They are more "private" in that they may provide varying degrees of benefit to different businesses or land owners. As a result, they raise a greater possibility of redistribution among the landowners or businesses who pay BID assessments. Retailers who depend on walk-in trade, and office building owners, who need to demonstrate to potential tenants that their facilities are located in a clean and safe area, may receive more benefits than wholesalers or industrial producers. If BID-provided policing and social services present serious questions of BID accountability to the city and to the norms applicable to

join New York City in lawsuit concerning enforcement of violations of city's administrative code).

265. Ga. Code Ann. § 36-43-8 (1993).

266. See N.J. Stat. Ann. $\S 40: 56-71$ (West 1992).

267. See id. at $\S 40: 56-77$ (b) (2). See also Fanelli v. City of Trenton, 641 A.2d 541, 543-49 (N.J. 1994) (upholding Trenton ordinance adopted pursuant to state BID enabling legislation banning hawking, peddling, and street vending within a BID). 
the public sector, BID business services raise questions concerning BID accountability to a BID's own private sector constituents.

\section{Governance}

Like formation, BID governance typically combines formal roles for both city hall and district landowners or firms. In a few places, BIDs may be governed by formally independent public authorities-although even then, important decisions may require the consent of the municipality. ${ }^{268}$ More commonly, state laws provide that the governing body of the municipality shall be the governing authority of the BID, but then require the creation of advisory boards or managing bodies dominated by representatives of property owners or businesses. Municipalities may establish these entities even when they are not required to do so by state law. Although technically not governing bodies, they exercise considerable control over BID operations. Indeed, the board of directors of the BID advisory board or administrative body is commonly referred to as "the BID" in much the same way as the municipal government is called "the city."

Where labeled "advisory," the BID board is directed to make recommendations concerning the BID's program and finances to the city government, which is free to adopt, modify, or reject the board's recommendations. ${ }^{269}$ In a few states, the special boards created to advise the municipal government on the initial service plan for the BID may be asked to administer the district once it is established.270 In other states, the district-level boards are officially administrative rather than advisory entities.

In several states, the BID enabling legislation requires, or expressly authorizes, the municipality to contract with a not-for-profit corporation, a business association, or other independent entity for the day-to-day management of the BID. ${ }^{271}$ These entities, known as "district management corporations" 272 or "district management associations," may predate the formation of the BID. A local development corporation or a

268. In Pennsylvania, for example, BIDs are created under a 1980 amendment to a 1945 law that provides for the creation of autonomous financing authorities. As a "business district authority," a Pennsylvania BID is legally independent of the municipality that created it. See PDC, supra note 69, at 3, 8. Nevertheless, even in Pennsylvania the municipality has a role in the governance of the BID, including the power to appoint the members of the BID board of directors, and power to veto changes in the service plan or method of assessment. See id. at 17, 26.

269. See Minn. Stat. Ann. $\S 428$ A.07 (West Supp. 1999) (before municipality may create special services district, a special appointed advisory board must be given opportunity to review and comment).

270. See, e.g., Neb. Rev. Stat. § 19-4021 (1997).

271. See, e.g., Ala. Code $\S \S 11-54 \mathrm{~B}-1$ (a), 11-54B-11 (1994); Del. Code Ann. tit. 22, $\S 1504$ (1997); Idaho Code $\S 50-2611$ (1994); N.M. Stat. Ann. § 3-63-11 (Michie 1995); Tenn. Code Ann. §§ 7-84-502(1), 7-84-519 (1998); PPS, supra note 11, at 28.

272. See, e.g., N.J. Stat. Ann. §§ 40:56-66(c), 40:56-83, 40:56-84 (West 1992). 
chamber of commerce may be given the contract to manage a BID. ${ }^{273}$ Alternatively, the managing body may be established by the municipality $^{274}$ or by the BID's sponsors. ${ }^{275}$ In New York, for example, incorporation of a not-for-profit district management association ("DMA") is an integral part of the process of the creation of a BID: BID assessments are collected by the city's tax department and remitted to the BID only pursuant to a contract between the city government and the DMA. ${ }^{276}$

Although a "management" entity and not a governing authority, 277 the DMA, in the view of those who work with BIDs, is "responsible for the policy and fiduciary functions of the BID."278 It sets the budget, hires staff, evaluates programs and staff performance, and makes recommendations to the city council for changes in the assessment rate and in the BID's program. ${ }^{279}$ The city government is likely to leave the BID's day-today operations to the DMA. The city will get involved in BID programs or finances only when the district advisory or management body seeks to make a basic change in the district's structure-to increase the assessment level, revise the assessment formula, issue bonds, or alter significantly the plan of services and improvements.

These bodies tend to view themselves as private agencies rather than arms of the city government. ${ }^{280}$ In a technical sense they may be right.

273. See, e.g., Idaho Code $§ 50-2611$ (1995); Miss. Code Ann. § 21-43-105(a) (1990); Wash. Rev. Code Ann. § 35.87A.110 (West 1990). See also Or. Rev. Stat. § 223.119 (1993) ("An existing association of property owners or tenants may enter into an agreement with the city to provide the proposed economic improvement.").

274. See, e.g., Del. Code Ann. tit. 22, §1504 (1997) (outlining the procedures governing the "creation and powers of the authority or management company").

275. See, e.g., Tenn. Code Ann. § 7-84-519(a) (1998) (municipal governing body may either create a board or appoint an existing organization to act as an "advisory board ... for the purpose of administering activities within and for the district"). In Mississippi, district property owners designate the district management group. The group proposed to manage the district is identified in the plan voted upon by district property owners. See Miss. Code Ann. § 21-43-121 (1990). The district management group can be a department of local government, a non-profit corporation, chamber of commerce, or downtown development corporation. See id. at $§ 21-43-105$.

276. See Managing the Micropolis, supra note 96, at 7-10 (describing how conflict among property owners over composition of DMA became the central concern in New York City Council consideration of NoHo BID).

277. See, e.g., Mich. Comp. Laws Ann. § 125.981(3) (West 1997) (providing for "a board for the management of [ ] activities" when a city establishes a "principal shopping district"); Va. Code Ann. § 15.2-2403(9) (Michie 1997) (providing for "a development board or other body" for "control and management of [such] funds" as city council may appropriate to use of "special service district"). But see Del. Code Ann., tit. 22, $\$ 1503$ (a) (2) (1997) ("authority or management company which will govern such district”); D.C. Code Ann. § 1-2278(a) (1998 Supp.) ("board of each BID corporation shall govern the BID corporation").

278. The BID Manual, supra note 93, at 38 .

279. See id. at 35,38 .

280. In refusing to provide information concerning executive salaries, the general counsel of the Grand Central BID's DMA stated: "We believe neither the public nor the city is entitled to that information .... We're a private agency, not a city agency." Feiden, 
The DMA is formally incorporated as a private not-for-profit corporation. Nevertheless, it has an important public component since it is called into existence as part of the BID formation process, ${ }^{281}$ depends on funds collected by the city, receives its authority pursuant to a contract with the city, and is entrusted with the responsibility of managing a public district.

The interplay of public and private in BID governance may get murkier still. The DMA may have formal responsibility for district operations, but the actual production of BID services is often undertaken by private firms pursuant to a contract with the DMA. A BID may contract for both field services, such as security and street cleaning, as well as for management services. ${ }^{282}$ This is more common for DMAs with smaller budgets that are unable to hire a full complement of staff. In these situations, the actual administration of the BID, including oversight of BID services to property owners and businesses, is actually handled by another entity, such as a local development corporation or a neighborhood chamber of commerce. Indeed, this other entity may be the organization that sponsored the creation of the BID. ${ }^{283}$ Members of the boards of directors of DMAs, or the appointed managers of BID operations, may have affiliations with entities that provide services to the BID. ${ }^{284}$ This can raise the possibility of self-dealing. ${ }^{285}$ Neighborhood organizations may seek to use the BID formation process to create a mechanism for levying assessments and, by a management contract, channeling the resulting revenues into the sponsor's treasury. ${ }^{286}$ Although DMA contracts with private firms for administrative, policing, sanitation, and other services are subject to city government oversight, it is difficult to assess the degree of city government deference to, or supervision of, BID managing bodies. The proliferation of BIDs and their wide range of activities may strain the ca-

supra note 27 , at 30 . The DMA relented when the City threatened to disapprove the BID's proposed bond issue if the information was not provided. See id.

281. The role of a city government in calling a BID managing body into existence was clearly displayed in New York City in 1998. In July, the city, dissatisfied with the Grand Central Partnership's stewardship of the Grand Central BID, declined to renew the Partnership's contract to manage the BID. Ultimately, members of the Partnership board, including its interim chairman, broke away and founded a new managing body, the Midtown East District Management Association, intending to satisfy the city. See Terry Pristin, Charges Fly as Mayor is Accused of Dismantling Grand Central Civic Group, N.Y. Times, Dec. 4, 1998, at B3.

282. See The BID Manual, supra note 93, at 20.

283. See id. at 55 .

284. See, e.g., Cities Within Cities, supra note 181, at 40-42. Statutes in other states contemplate that members of a BID's boards of directors, or a BID manager, may have affiliations with organizations that provide services to the BID. See, e.g., Kan. Stat. Ann. $\S 12-1790$ (1991) (no prohibition on members of a BID advisory board also serving on the board of directors of a not-for-profit corporation with which the city may contract to provide specified services within the district); W. Va. Code § 8-13A-11(c) (1998) (same).

285. See Cities Within Cities, supra note 181, at 31-32.

286. See ODDA, supra note 97, at 4-5, 11-12 (noting that the organization hired to manage a BID is likely to receive between two-thirds and $90 \%$ of its revenues from the BID). 
pacity of city administrators and elected officials to check the possibilities of corruption.

Who sits on the boards of these advisory and administrative bodies, and how do they get to these positions? Some state laws limit membership to owners of real property or businesses in the district. ${ }^{287}$ More commonly, states permit other people-particularly residents-to serve, but require that a majority of board members be property owners, businesses, persons "having an interest" 288 in property in the district, or persons subject to district assessments. ${ }^{289}$ Other states open membership to residents or electors of the district. ${ }^{290}$ Many states provide for participation by government officials. ${ }^{291}$

Businesspeople, especially landowners, generally dominate the membership of these boards, even when that is not required by state enabling legislation. One study of the eight largest New York City BIDs found that $67 \%$ of the members of the boards of directors of BID DMAs were businesspeople, primarily landlords, property owners, real estate developers, retailers, bankers, and lenders. ${ }^{292}$ A similar fraction $(65.5 \%)$ of the boards of BIDs in five other major cities were businesspeople, with that figure rising to $75 \%$ if "legal professionals" are grouped with businesspeople. ${ }^{293}$ The remaining board members were public officials, residents, members of community boards, and representatives of not-forprofit organizations. ${ }^{294}$

287. See, e.g., Ala. Code § 11-54B-11(b)(5) (1994); Ark. Code Ann. § 14-184 111(a)(1) (A) (Michie 1998); Mont. Code Ann. § 7-12-1121 (1997); see also Del. Code Ann., tit. $22 \S 1503(\mathrm{a})(2)$ (1997) (allowing owners of commercial property or their designees to be members).

288. Mich. Comp. Laws Ann. $§ 125.1654$ (West 1994) (detailing composition of governing board of downtown development authority).

289. See, e.g., D.C. Code Ann. § 1-2277(a) (1988 Supp.); La. Rev. Stat. Ann. $\S 33: 2720.3 \mathrm{D}$ (West 1988); Mo. Ann. Stat. § 71.794(4)(i) (West 1998). In California, the advisory board "may" be limited to persons paying assessments. See Cal. Sts. \& High. Code $\S 36530$ (West Supp. 1999).

290. Oregon does not require an advisory committee for its BIDs, but provides that if a city creates such a committee "the council shall strongly consider appointment of owners of property within the . . . district to the advisory committee.” Or. Rev. Stat. § 223.119 (1997). Connecticut imposes no restrictions on who may serve on the board of commissioners of a special services district. Conn. Gen. Stat. Ann. § 7-339q (West 1989).

291. See, e.g., Tenn. Code Ann. § 7-84-519 (1998); N.Y. Gen. Mun. Law § 980-m(b) (McKinney Supp. 1999); Mich. Stat. Ann. § 5.3533(1)(1)(h) (Law. Co-op. 1985).

292. See Houstoun, Betting, supra note 2, at 14 (noting that, on average, 20 out of 30 people on the board were businesspeople).

293. See id. Subsequently, Houstoun reported that boards of larger BIDs tend to be dominated by developers and major property owners, while boards of smaller BIDs are more likely to be dominated by merchants. See Houstoun, BIDs, supra note 1, at 7 . See also PDC, supra note 69, at 11 (showing different compositions of the boards of smaller BIDs found in Allentown, Mt. Pleasant, and Pottstown, and of a larger BID in Philadelphia).

294. See Houstoun, Betting, supra note 2, at 14. Perhaps due to a state law requiring that four city officials be represented on DMA boards in New York, public officials 
BID boards may be appointed by the city government or elected by a district-level constituency, with appointment the more common route. Even with appointed boards, state laws frequently require that all or most board members be landowners, businesses, or residents of the district. In some states, appointments must be made from a list prepared by the local chamber of commerce, ${ }^{295}$ or appointees must have expertise in particular fields like real estate development, finance, or retail. ${ }^{296}$ The largest property owners are likely to have representatives on the board. ${ }^{297}$ Even with elected boards, the election may be limited to the owners of property subject to assessment, ${ }^{298}$ or votes may be weighted according to the valuation of the property or the assessments the voters pay to the district. 299 Colorado is the rare state in which a board may be elected by district electors, without a majority of seats committed to property owners. But such an arrangement can occur only if a majority of district landowners approve; otherwise, BID boards are appointed. ${ }^{300}$

Whether elected or appointed, the model for the DMA board is that of the board of directors of a not-for-profit corporation rather than a city council. The group that sponsored the BID proposal becomes the nucleus for the first board of directors; in effect, it nominates itself when it incorporates the DMA and wins city government approval to manage the BID. ${ }^{301}$ Thereafter, as the terms of the original board members expire, the board either fills its own vacancies or, if elected, conducts elections in which those property owners or tenants eligible to vote cast ballots to elect new board members (or reelect old ones). ${ }^{302}$ Typically, the board nominates a slate of directors, and the elections occur at a meeting of the DMA membership rather than at a public election. ${ }^{303}$

accounted for about $15 \%$ of board members, as opposed to only $8 \%$ in the other cities. See N.Y. Gen. Mun. Law. § 980 -m (McKinney Supp. 1999).

295. See La. Rev. Stat. Ann. § 33:2740.3(D) (1) (West 1988).

296. See Tex. Loc. Gov't Code Ann. § 375.064(f) (West Supp. 1999).

297. The Dallas Downtown Improvement District is managed by Dallas CBD Enterprises, Inc. Its board of directors has 30 members: three represent the City; six represent tenants, particularly law firms, banks, and accounting firms; and 21 represent property owners. Any property owner who owns $1 / 21$ of the total taxable real property in the district is entitled to a seat. The balance of the property owner directors is chosen to represent each quartile of property ownership by value. See Downtown Improvement District, supra note 2, at 10-11.

298. See, e.g., Mass. Ann. Laws ch. 40D, $§ 5$ (Law. Co-op. 1989).

299. Even when votes are allocated according to property values or assessments, some jurisdictions cap the maximum number of votes any property owner may cast or provide special protections for smaller owners. See, e.g., Ala. Code § 11-54B-11(b) (5) (1994); 1996 D.C. Stat. $134 \S 11$ (c); N.Y. Gen. Mun. Law $\S 980$-m(a) (McKinney Supp. 1999) (providing that if, in the election of members of the board of directors of the DMA, property owner votes are weighted in proportion to the assessments levied against their properties, no owner shall be assigned more than one-third of the total votes cast).

300. See Colo. Rev. Stat. Ann. § 31-25-1209(1) (b), (d) (West Supp. 1998).

301. See, e.g., PDC, supra note 69, at 12.

302. See, e.g., Ala. Code $\S 11-54 \mathrm{~B}-11$ (b) (1994).

303. See, e.g., Ohio Rev. Code Ann. § 1710.04(A) (West 1994). 
In many cases, then, the government of a BID consists of both the municipality, which is technically the governing body, and an advisory committee or management committee composed primarily of representatives of landowners or businesses in the district. If the state follows the management committee route, the BID body is particularly likely to be separately incorporated and to have considerable autonomy in conducting BID operations. Although major actions-such as a change in boundaries, in the assessment formula, or in the BID's program, or the issuance of bonded debt to finance a program of capital improvementswill require city approval, the BID board may be autonomous in practice even if it is subject to municipal oversight in theory.

\section{The Genealogy of BIDs}

BIDs are a relatively recent development in urban governance, but they have deep roots in legal structures, policy initiatives, and economic forces that have long shaped America's cities. The BID emerged out of two local legal institutions-the special assessment and the special purpose district. By drawing on these pre-existing legal forms, BIDs have been able to secure a distinctive revenue stream and a substantial measure of autonomy from municipal government. The BID is also an urban development program. Its organization and functions reflect a half-century of efforts to revitalize American cities and, especially, to respond to the challenges posed by suburban commercial growth. An appreciation of the genealogy of BIDs may help situate BIDs in the matrix of publicprivate relationships central to local government and provide a basis for considering the current legal and policy debates over BIDs.

\section{A. Special Assessments, Special Purpose Districts, and the Legal Roots of BIDs}

The special assessment and the special purpose district are two legal structures that have long provided mechanisms for funding and managing local public sector activities outside of the rules and controls applicable to most municipal governments. The special assessment and the special purpose district also embody the local tradition of blending public and private elements. The BID combines aspects of both the special assessment and the special purpose district, but BIDs extend these older structures well beyond their traditional uses.

1. Special Assessments. - Special assessments have played a role in municipal finance since the early nineteenth century. ${ }^{304}$ Special assessments have been used to pay for building and improving streets, sidewalks, sewers, street lighting, and utilities abutting, adjacent to, or con-

304. See, e.g., Stephen Diamond, The Death and Transfiguration of Benefit Taxation: Special Assessments in Nineteenth-Century America, 12 J. Legal Stud. 201, 204-06 (1983) (special assessments originated in New York at end of the eighteenth century and became "an increasingly common financing device" after about 1830). See generally Victor Rosewater, Special Assessments: A Study in Municipal Finance (2d ed. 1998). 
necting the land of the property owners subject to the assessment. ${ }^{305}$ In theory, these improvements provide both general, or "public," benefits to the municipality and special, or "private," benefits to the abutting or adjacent landowners. The public benefit justifies public action to provide the improvement; the private benefit justifies requiring landowners to defray a portion of the municipality's expenses. ${ }^{306}$

The special assessment has elements of both the property tax and the user fee. Like the property tax, the assessment is imposed on landowners, and it is coercive; the benefited landowner cannot choose to forego the planned improvement and thereby avoid the assessment. ${ }^{307}$ But, unlike general taxation-and more like the user fee-the assessment is justified and measured not by wealth or ability to pay but by the benefit that results from the improvement. In theory, a landowner may not be assessed more than the value of the benefit, and the money raised by assessment goes back to those assessed in the form of a direct benefit to their land. ${ }^{308}$ Special assessments are frequently exempt from many of the state constitutional rules applicable to property taxation, such as the mandate that taxes be uniformly applied to all taxpayers; ${ }^{309}$ the requirement of voter approval of tax increases; ${ }^{310}$ or the limits some states impose on property tax rates or yields. ${ }^{311}$ An assessment payer is protected from municipal rapacity not by substantive and procedural tax limits, but by the benefit principle. ${ }^{312}$

BID finances are strongly shaped by the special assessment experience. Most BIDs receive most of their funds from special assessments on property owners. Indeed, many state BID laws track special assessment laws with respect to the formulas used for determining, and the procedures for challenging, assessments. BIDs also rely on the special assessment principle of encapsulation-that assessments collected within an

305. See, e.g., Property Owners Ass'n v. City of Ketchikan, 781 P.2d 567, 569 (Alaska 1989) (special assessment used to finance roads, water, sewers, and telephone and power lines); Rinker Materials Corp. v. Town of Lake Park, 494 So.2d 1123, 1124 (Fla. 1986) (roadway, drainage, water, and sewer improvements financed by special assessment against properties "abutting, adjoining, or contiguous to and specially benefitted by" the improvements); Rosewater, supra note 304, at 64 .

306. See Norwood v. Baker, 172 U.S. 269, 289 (1898); Rosewater, supra note 304, at 93-99.

307. See, e.g., Kirchner v. Giebink, 552 A.2d 372 (Vt. 1988); Rosewater, supra note 304 , at $93-94$.

308. Similarly, to assure that the assessment is not used to provide a net revenue gain to the municipality, landowners' payments are capped by the cost of the improvement as well as by the value of the benefit. See, e.g., Wolfe v. City of Avon, 463 N.E.2d 1251, 1254 (Ohio 1984); Rosewater, supra note 304, at 100-06.

309. See, e.g., Zelinger v. City \& County of Denver, 724 P.2d 1356, 1358 (Colo. 1986); In re Woodstock Special Assessment, 450 N.E.2d 960, 972 (Ill. App. Ct. 1983); Public Serv. Co. v. Northwest Rogers County Fire Protection Dist., 675 P.2d 134, 141-42 (Okla. 1983).

310. See, e.g., Zahner v. City of Perryville, 813 S.W.2d 855, 858-59 (Mo. 1991).

311. See, e.g., Knox v. City of Orland, 841 P.2d 144, 149 (Cal. 1992).

312. See, e.g., Rosewater, supra note 304 , at $99-100,115-17$. 
area must be spent in and for that area. BID assessments may be collected by city tax collectors, but, like other assessments, they are not available for general city purposes and are not considered a part of the municipal treasury.

BIDs, however, differ from their special assessment progenitors in several ways. First, BID assessments are used primarily to finance municipal services in older, established areas rather than to provide physical infrastructure for new and growing areas. ${ }^{313}$ Historically, the special assessment was often a one-shot device to fund basic facilities for new areas. As Professor Stephen Diamond has suggested, the special assessment functioned as a kind of admission charge for residents of newly developed city districts. Municipal residents in older parts of the city, who had already paid for their own streets, sidewalks, and sewers, resented being taxed to finance improvements in newer parts of town. ${ }^{314}$ The newcomers were forced to shoulder the costs of their infrastructure through assessments, but then, "[o]nce that entrance fee into the municipal general tax pool had been paid," public financing of general services and other improvements would follow. ${ }^{315}$ BIDs, however, serve older, commercial areas rather than newer, residential ones. More importantly, the BID does not go out of business once new infrastructure is in place. Rather, it provides security, street maintenance, sanitation, and marketing services on an ongoing basis. BIDs are, potentially, long-term structures.

Second, many BID expenditures lack the clear benefit to particular parcels characteristic of the classic special assessment. The most common methods of calculating special assessments-reflecting the original use of the assessment to finance abutting street and road improvements, drainage, or utilities-are front-footage, square footage, or the number of service line connections. ${ }^{316}$ BID services, however, provide more diffuse benefits that run to the district as a whole, but not necessarily to every individual landowner. ${ }^{317}$ Some BIDs provide programs of assistance targeted to some landowners or firms but not others. BID expenditures to cultivate a distinctive image may be in tension with the interests of particular landowners or businesses whose activities do not fit the image.

313. Although assessments have traditionally been associated with the financing of infrastructure, they have sometimes been used to finance services. See, e.g., Diamond, supra note 304, at 233; Eugene McQuillin, 14 The Law of Municipal Corporations $§ 38.01$ (3d ed. 1987).

314. McQuillin, supra note 314 , at $\S 38.01$.

315. Diamond, supra note 304, at 238.

316. See, e.g., Rinker Materials Corp. v. Town of Lake Park, 494 So.2d 1123, 1124-26 (Fla. 1986); Mullins v. City of El Dorado, 436 P.2d 837, 841 (Kan. 1968); Lunderberg v. City of St. Peter, 398 N.W.2d 579, 583 (Minn. Ct. App. 1986); Zahner v. City of Perryville, 813 S.W.2d 855, 859 (Mo. 1991); McNally v. Township of Teaneck, 334 A.2d 67, 71 (N.J. Super. Ct. Law Div. 1975).

317. Those with private carting and security arrangements may receive less benefit from BID services. Similarly, businesses that do not rely on street traffic or walk-in trade may benefit less from programs that are aimed at increasing the amount of activity on the streets. 
Even where there is no conflict, it may be difficult to establish a nexus between BID expenditures and benefits to assessment payers. ${ }^{318}$

Third, in the traditional special assessment context, the special assessment district is a unit of territory, not of governance. The municipality determines and implements the special assessment program. An assessment district is ordinarily an object of municipal action, not a subject-an area, not a legal entity. ${ }^{319}$ The distinctive feature of many BIDs is the advisory or management body, composed in part of representatives of those subject to BID assessments, entrusted with some responsibility for determining and carrying out the BID's program. These district-specific bodies make BIDs institutions of decisionmaking in their own right, rather than just financing mechanisms for their municipalities. They distinguish BIDs from most special assessment districts and cause BIDs to resemble other forms of special districts. ${ }^{320}$

2. Special Purpose Districts. - There are nearly 30,000 independent special purpose districts in the United States, and the special purpose district is our most common and most rapidly growing form of local government. ${ }^{321}$ There are enormous differences among special districts, in terms of geographical scope, finances, functions, and governance, with considerable variations across the states and types of districts, so that general statements about these districts require qualification and are subject to error. ${ }^{322}$ But for the purpose of situating BIDs within the structures of local government, a few general observations should be attempted. ${ }^{323}$

318. Driven by the legal and political desirability of funding area-wide physical improvements in growing areas without raising general taxes, states have begun to authorize the calculation of assessments based on the value of the properties assessed. These assessments resemble general ad valorem property taxation. See, e.g., City of Boca Raton v. State of Florida, 595 So.2d 25, 30-31 (Fla. 1992); Bellevue Assocs. v. City of Bellevue, 741 P.2d 993, 995 (Wash. 1987).

319. See McQuillin, supra note 313 , at $§ 38.46$.

320. A municipality authorizing a traditional special assessment may create a board of commissioners, but that board is primarily concerned with determining the assessment imposed on individual parcels. It does not develop or implement a program for using the assessments. In a few states, the legislation authorizing BIDs follows this pattern. The municipality imposes the special assessment with little formal input from district interests, and it undertakes the program the assessments finance. In these states, the only role for BID board commissioners is to determine or review individual assessments.

321. See, e.g., David L. Chicoine \& Norman Walzer, Governmental Structure and Local Public Finance 8-16 (1985) (detailing the growth of special purpose districts and suggesting explanations for such growth); William G. Colman, State and Local Government and Public-Private Partnerships 22 (1989) (describing the main functions of special district governments which operate as entities independent from general purpose local governments); Douglas R. Porter et al., Special Districts: A Useful Technique for Financing Infrastructure 1-9 (2d ed. 1990) (citing the growth in, and major trends of, special districts).

322. On the difficulty of making generalizations about special districts within one state, see generally Mary Kay Falconer, Special Districts: The "Other" Local Governments-Definition, Creation and Dissolution, 18 Stetson L. Rev. 583 (1989).

323. See Hudson, supra note 148 , at $62-71$ (considering BIDs in the context of special districts). 
Special purpose districts perform a single or a very small number of closely related functions-hence the notion of the special, or limited purpose district, as opposed to the general purpose city, township, or county. ${ }^{324}$ Unlike special assessment districts, special purpose districts are legally independent of other local governments. ${ }^{325}$ They are governed by their own boards, which are either appointed by the state or by other local governments or are elected by residents or landowners from within the district. ${ }^{326}$ General purpose local governments may have a role in the formation of a district, but the districts typically enjoy fiscal and programmatic autonomy. ${ }^{327}$

Most independent special purpose districts finance, construct, and operate physical infrastructure dealing with water supply, sewerage, transportation, utilities, parks, schools, health facilities, or housing. Some districts provide services without engaging in the production of capital improvements, but such services account for less than four percent of all special district expenditures. ${ }^{328}$ Special districts are often authorized to issue tax-exempt revenue bonds. These bonds are typically backed by the revenues from the charges for the services the district provides from the projects financed by the debt. Such user charges are a principal source of special district revenues. ${ }^{329}$

Special districts are created for a variety of reasons. The special district device permits the state to create a government whose territory and powers are tailored to the scope of the problem to be addressed. Special districts provide a means of addressing regional problems, such as irrigation, water supply, flood control, electric power, and transportation, without consolidating or otherwise disturbing the autonomy of the cities within the region. ${ }^{330}$

Special purpose districts are also used to finance capital facilities in rapidly growing but unincorporated tracts on the fringe of metropolitan

324. See Kathryn A. Foster, The Political Economy of Special-Purpose Government 12-13 (1997).

325. See id. at $10-11$.

326. See id. at 12.

327. See, e.g., James Leigland, External Controls on Public Authorities and Other Special Purpose Governments, in Public Authorities and Public Policy: The Business of Government 31, 41-45 (Jerry Mitchell ed., 1992) (" $[T]$ he benefits provided by the relative operational freedom of these entities outweigh the costs involved in instituting additional controls.").

328. See Porter et al., supra note 321 , at 5.

329. See id. In $1986-87$, special districts collected $\$ 50.7$ billion in revenue, of which $\$ 27.4$ billion came from charges for services and utility revenues for utility districts. An additional $\$ 10.8$ billion came from intergovernmental grants, and $\$ 5.5$ billion came from taxes. Special assessments accounted for only $\$ 454$ million, or far less than the $\$ 3.5$ billion in interest earnings. See id. at 5 fig. 6.

330. See Foster, supra note 324, at 123 (finding that $23.3 \%$ of special districts are regional in scope). 
areas. ${ }^{331}$ People who prefer to avoid the redistribution and regulation that may result from a general purpose local government can use special districts to obtain new physical infrastructure and basic services without having to incorporate a new municipality.

Special purpose districts are often used "as a means of circumventing restrictive tax and debt limitations." ${ }^{332}$ Many state courts hold that state constitutional provisions limiting local taxing and borrowing do not apply to special districts. The goal of evading state fiscal limits explains the large number of special purpose districts that are territorially coterminous with existing municipal governments. ${ }^{333}$

Special districts "may also be created in response to a desire for autonomy and independence by those who have an interest in the peculiar function or service of the district." 334 This may reflect the sense that a function will be more effectively undertaken and better financed if an entire government is specifically devoted to it. Many special district functions are seen as technical or engineering activities so that special districts may be established on the theory that placing the function in an independent entity keeps it "out of politics." 335

A BID is a special district but it differs from most other special districts in several significant ways. Unlike most other special districts, physical infrastructure tends to be a relatively small part of BID programs, and relatively few BIDs issue debt. BIDs are primarily funded by assessments, not user charges. Nearly half of all special districts are coterminous with counties or cities or are regional in scope; the remaining smaller special districts typically serve unincorporated areas on the urban fringe. ${ }^{336}$ By contrast, a BID is generally a very small subunit of a city and operates in the city's commercial heart. Most special purpose districts engage in just one function, whereas BIDs are authorized to provide a broad range of services and improvements.

Most special districts have greater legal autonomy from general purpose local governments than do most BIDs, although this is more a matter of degree than a categorical distinction. The thousands of special districts that overlap multiple local governments or operate outside unincorporated areas are generally free from control by other local governments. The states have authority over those districts, but in practice it

331. See City of Scottsdale v. McDowell Mountain Irrigation \& Drainage Dist., 483 P.2d 532 (Ariz. 1971) (applying Arizona statue prohibiting the creation of special purpose districts within six miles of incorporated cities and towns); Nancy Burns, The Formation of American Local Governments: Private Values in Public Institutions 25-30, 100 (1994); Foster, supra note 324, at 19-20.

332. Daniel R. Mandelker et al., State and Local Government in a Federal System 90 (2d ed. 1996).

333. See Foster, supra note 324 , at 18,123 (finding that $21.1 \%$ of districts are coterminous with municipalities).

334. Mandelker et al., supra note 332 , at 90 .

335. Id. See also Porter et al., supra note 321 , at 42.

336. See Foster, supra note 324, at 109, 123. 
appears that states do not closely oversee their activities. The special purpose districts that are coterminous with general purpose local governments are likely to have closer ties to the counties or municipalities that create them. Their governing board members are often appointed by general purpose government officials. But these districts were often created to avoid state fiscal limits; to avoid judicial invalidation of the districts, local governments may have to give these districts some measure of formal autonomy over their program and finances. BIDs, in general, are more legally subordinate to the localities that create them. Of course, the actual relationship between a special purpose district and its parent local government may not match the relationship prescribed in the statute books. As a result, it is more difficult to determine how BIDs differ from other special districts in terms of their autonomy from city governments.

BIDs embody the basic elements of the special district device: territorial flexibility, institutional independence and distinctive decisionmaking capacity. ${ }^{337}$ The BID is, in effect, a union of the special assessment district and the independent special district, combining the distinctive revenue stream of the former with the governance structure and relative autonomy of the latter. However, BIDs differ from both types of traditional districts in their focus on urban commercial neighborhoods, in their provision of services rather than physical infrastructure, and in the wide range of activities individual BIDs are authorized to undertake.

\section{B. The BID as Urban Development Program}

For more than a half-century, America's cities have struggled to meet the challenges of suburbanization, new regional growth patterns, and a changing economy. Cities in most metropolitan areas have suffered declines in population, employment, inflation-adjusted median family income, and retail activity-either relative to the surrounding suburbs, or in absolute terms. ${ }^{338}$ A variety of federal, state and local programs have sought to reverse these declines and restore the cities to their pre-1945 economic primacy. These policies have had, at best, mixed success. Nevertheless, several major themes in urban development policy are highly relevant to the analysis of BIDs. BIDs can be seen as the latest effort by cities to meet the economic competition posed by suburban, and, increasingly, exurban growth.

1. BIDs and Postwar Urban Development Policy. - Modern American urban development policy has been oriented toward promoting and sub-

337. As the Pennsylvania Downtown Center noted in urging Pennsylvania cities to consider the creation of BIDs-known in Pennsylvania as business district authorities-for their downtowns, because a BID is "a separate legal entity . . . there are financial, administrative, and political reasons" for creating one. PDC, supra note 69 , at 3 .

338. See, e.g., Susan S. Fainstein \& Norman I. Fainstein, Economic Change, National Policy, and the System of Cities, in Restructuring the City: The Political Economy of Urban Redevelopment 4 (Susan S. Fainstein et al. eds., 1983) [hereinafter Restructuring the City]. 
sidizing capital investment in commercial, industrial, retail, or tourist-promotion activities, rather than in training labor, subsidizing wages, or providing other benefits to workers or residents. ${ }^{339}$ Urban development policy has "emphasized the rebuilding and rejuvenation of downtown areas" 340 rather than other city neighborhoods. City governments strive to make their downtowns attractive as corporate headquarters, offices for service economy firms, settings for white collar workers, affluent shoppers, suburbanites interested in the arts and entertainment, tourists, and convention-goers. ${ }^{341}$

American cities have long sought to provide an environment conducive to business, but in the past government programs focused on the construction of public infrastructure-roads, bridges, wharves, streets, parks, schools, libraries, and utilities - and the protection of property and maintenance of order. ${ }^{342}$ These programs provided public benefits generally, even as they enhanced the ability of a city's businesses to compete

339. See, e.g., Peter K. Eisinger, The Rise of the Entrepreneurial State 29 (1988). The most dramatic instance of this bias is surely the fate of the federal Urban Renewal program. Originally conceived of and justified as a housing program that would improve residential areas by razing substandard structures and replacing them with improved dwellings, urban renewal became a mechanism for demolishing residential neighborhoods and replacing them with commercial and industrial developments. See, e.g., Bernard J. Frieden \& Lynne B. Sagalyn, Downtown, Inc.: How America Rebuilds Cities 22-37 (1989); Gregory D. Squires, Partnership and the Pursuit of the Private City, in Urban Life in Transition 204-05 (M. Gottdiener \& Chris Pickvance eds., 1991) [hereinafter Urban Life in Transition]. Other federal programs, such as Model Cities, Community Development Block Grants, and Urban Development Action Grants, also tended to focus on promoting investment in commercial and industrial activity rather than in housing, education, job training, or assistance to residents or workers. See, e.g., Eisinger, supra, at 106-22. On the destructive effects of Urban Renewal and Model Cities on the working class and poor in one city, New Bedford, Massachusetts, see Ross J. Gittell, Renewing Cities 100-01 (1992).

340. Mickey Lauria et al., The Revitalization of New Orleans, in Urban Revitalization: Policies and Programs 102, 124 (Fritz W. Wagner et al. eds., 1995) [hereinafter Urban Revitalization]. See also Dennis Keating et al., Cleveland: Post-Populist Public-Private Partnerships, in Unequal Partnerships: The Political Economy of Urban Redevelopment in Postwar America 121, 129-30 (Gregory D. Squires ed., 1989) [hereinafter Unequal Partnerships] (tracing Urban Development Action Grants funds in Cleveland); June Manning Thomas, Detroit: The Centrifugal City, in Unequal Partnerships, supra, at 142, 153 (noting that funds which could have been spent on developing neighborhoods were instead used to develop downtown areas).

341. See, e.g., David W. Bartelt, Renewing Center City Philadelphia: Whose City? Which Public's Interests?, in Unequal Partnerships, supra note 340 , at 80, 81; Frieden \& Sagalyn, supra note 339, at 259-85; Keating et al., supra note 340, at 125; Jack Norman, Congenial Milwaukee: A Segregated City, in Unequal Partnerships, supra note 340, at 178, 200. Downtown strategies are not exclusively commercial; they may entail incentives for the construction of luxury housing to give downtowns a residential population that can be a market for downtown retail activity and cultural facilities. But the principal result of the downtown focus has been the construction of office buildings, convention centers, hotels, shopping malls, festival marketplaces, and stadiums in or adjacent to central business districts.

342. See, e.g., Hendrik Hartog, Public Property and Private Power: The Corporation of the City of New York in American Law, 1730-1870 (1983) (stating that government's 
with firms elsewhere. In recent decades, however, governments have turned to providing direct assistance to individual firms and to specific private projects. Local governments have used eminent domain to clear and assemble land; issued tax-exempt bonds to fund below-market rate loans to developers; given tax abatements for particular investments; and installed roads, sewers, water mains, or streets to enhance sites for development. More sophisticated or entrepreneurial local governments help developers secure private financing or broker the terms of development deals; work with firms or industries in developing new markets; or even take equity stakes in development projects. In short, the notion of the public purpose justifying local government action has evolved from enhancement of the business climate generally to targeted assistance to individual firms.

Structurally, "the cornerstone of economic development strategies of virtually all U.S. cities" 343 has been the public-private partnership. These often begin as coalitions of businesses or business leaders, ${ }^{344}$ particularly real estate interests, banks, retailers, publishers, and firms with considerable investments in downtowns. ${ }^{345}$ These committees would plan for downtown redevelopment and then seek public regulatory capacity and public funds to realize those plans. ${ }^{346}$ These private alliances evolved into public-private partnerships in which public and private officials sit together to set redevelopment policy. These partnerships may be institutionalized in public development corporations empowered to allocate federal and state funds, exercise eminent domain, acquire and dispose of land, issue tax-exempt debt, and use public resources to leverage private investment. ${ }^{347}$ Alternatively, the public-private partnership may be a not-

"most important function" was to "create a predictable and consistent environment within which th[e] private market economy would flourish").

343. Marc V. Levine, The Politics of Partnership: Urban Redevelopment Since 1945, in Unequal Partnerships, supra note 340, at 12.

344. See Perry Davis, Why Partnerships? Why Now?, in Public-Private Partnerships: Improving Urban Life 1 (Perry Davis ed., 1986).

345. See, e.g., Frieden \& Sagalyn, supra note 339, at 18.

346. Examples of downtown business committees include the Allegheny Conference on Community Development (Pittsburgh), the Greater Milwaukee Committee, Central Atlanta Progress, Inc., the Greater Philadelphia Movement the "Vault" (Boston), see Squires, supra note 339, at 205; Levine, supra note 343, at 19-20; the Downtown Council (Minneapolis), see Alex Schwartz, Rebuilding Downtown: A Case Study of Minneapolis, in Urban Revitalization, supra note 340, at 163, 172-73; and Downtown Denver, Inc., see Dennis R. Judd, From Cowtown to Sunbelt City: Boosterism and Economic Growth in Denver, in Restructuring the City, supra note 338, at $167,178-81$.

347. Operating outside the direct control of, and exempt from many of the legal restraints applicable to, city governments, these public-private institutions "formalize a cluster of elites" into "the central deal makers in the development process." Michael A. Pagano \& Ann O'M. Bowman, Cityscapes and Capital: The Politics of Urban Development 90, 87 (1995). Part of the impetus for these development authorities came from the federal urban renewal program. See Norman I. Fainstein \& Susan S. Fainstein, Regime Strategies, Communal Resistance, and Economic Forces, in Restructuring the City, supra note 338 , at $245-46$. 
for-profit corporation chartered by business leaders, with boards of directors composed of business, public, and other institutional representatives, such as hospitals and universities. ${ }^{348}$

Although the postwar decades have been a period of enormous direct public assistance to private investment, cities have sought to limit the commitment of their treasury funds. ${ }^{349}$ Cities have used federal and state grants and have taken advantage of the Internal Revenue Code to issue tax-exempt debt to pay for below-market rate loans to developers. When they put their own resources into projects, cities look for methods that do not entail direct expenditures, such as the lease or sale of city-owned property to developers or the provision of tax abatements to investors.

A particularly clever device for assisting development without the outlay of city funds-and a device with ramifications for the emergence of BIDs-has been the tax increment financing (TIF) district. Property in a TIF district is assessed at the same rate as other property in the city, but the incremental tax revenues attributable to development are reserved to pay the debt service on bonds used to finance new public improvements in the district on the theory that the public improvements stimulated the development. ${ }^{350}$ TIF is, thus, seen as "'development that pays for itself.' "351

To be sure, local governments have contributed significant sums to development projects. ${ }^{352}$ Even off-budget items like the abatements and loan guarantees have costs in terms of revenues foregone and the diversion of borrowed funds to private developments rather than other municipal needs. Still, municipal leaders appear to prefer to help development as much as possible without direct outlays to developers. Although most big city mayors have agreed with downtown business leaders on the primacy to be accorded to the central business district, direct assistance to big developers, investors, builders, and retailers is not always politically popular. Downtown leaders have a great deal of influence at city hall, but they do not cast a lot of votes on Election Day. In an era of tight budgets and fiscal stress, ${ }^{353}$ off-budget assistance may be more politic.

348. Although they generally lack the power of eminent domain or the ability to issue tax-exempt debt, these organizations can receive public grants and loans and commit public support to private endeavors. See Gittell, supra note 339, at 72-88; Pagano \& Bowman, supra note 347 , at 88-89.

349. See, e.g., Frieden \& Sagalyn, supra note 339, at 155-57, 248-49.

350. The assessed valuation of property in a TIF district is frozen. Revenues generated at the frozen valuation level continue to flow into municipal coffers, but revenues resulting from applying the tax rate to an increase in valuation are reserved to pay for bonds that funded investment in the district. See, e.g., James R. Paetsch \& Roger K. Dahlstrom, Tax Increment Financing: What It Is and How It Works, in Financing Economic Development: An Institutional Response 82, 83 (Richard D. Bingham et al. eds., 1990).

351. Id. at 82 .

352. See, e.g., Frieden \& Sagalyn, supra note 339, at 155.

353. See, e.g., Helen F. Ladd \& John Yinger, America's Ailing Cities: Fiscal Health and the Design of Urban Policy 3-16 (1991) (describing factors causing fiscal stress in American cities). 
BIDs reflect the postwar urban development experience in several ways. They are intended to benefit business activity rather than residents and are focused on business districts rather than residential neighborhoods. They utilize a public-private partnership structure. ${ }^{354}$ Many BIDs were sponsored by the very corporate alliances and public-private partnerships that have been active in downtown revitalization programs. The creation of a BID may be a part of a larger downtown renewal plan, with the BID formed to provide a higher level of public services to the mall, office park, convention center or tourism-oriented entertainment district that was the centerpiece of the downtown plan. Most importantly, BID programs carry forward the notion that assistance to business-including recruitment and retention of firms and the promotion and marketing of the goods and services of local firms-is in the public interest.

Yet, BIDs differ significantly from other postwar urban development programs. First, although BIDs are business-oriented, they are not necessarily downtown-oriented. Although the pattern in some cities is one big downtown BID, in many cities there are multiple BIDs. Many of New York City's forty BIDs, for example, are centered on neighborhood commercial strips that are far from the midtown and lower Manhattan business districts, both physically and economically. ${ }^{355}$ The activities of the BIDs outside central business districts are aimed less at enhancing the city's standing in the global economy, and more at helping businesses whose customers generally come from adjacent residential areas. They are less likely to be dominated by the city's power elite than by neighborhood landowners, shopkeepers and organizations who may have been ignored by development efforts focused on downtown.

Second, unlike many of the urban development projects of the last several decades, BIDs focus on the provision of street-level services and small-scale improvements to the public environment of streets, sidewalks and parks rather than the creation of hotels, convention centers, sports arenas and other megastructures. ${ }^{356}$ The BID approach to urban development more closely resembles the older tradition of improving the urban environment generally than the postwar approach of providing direct subsidies to specific firms.

Third, BIDs minimize the diversion of general public revenues to business interests. BIDs resemble TIF districts in the way they encapsulate revenues raised within a particular area to fund programs in that

354. According to a BID information guide published by the State of New Jersey, "a BID is a public-private partnership." New Jersey Dep't of Community Affairs, supra 175, at 4.

355. See, e.g., Terry Pristin, Improvements on a Small Scale; Brooklyn BID Makes Strides Despite Its Modest Budget, N.Y. Times, Feb. 20, 1999 at B1 (spotlighting activities of North Flatbush Avenue BID).

356. See ODDA, supra note 97 , at 2 ("[R]ather than funding . . . physical improvements," BIDs are intended "to fund the many nonphysical projects of a revitalization program"). 
area. But even TIF projects entail the diversion of public revenues to private development projects. ${ }^{357}$ By contrast, BIDs draw relatively little public money from outside the districts. BID assessments are public money, but it is the district's public money specially collected for BID purposes, not that of other city, state, or federal taxpayers.

Finally, BIDs represent a change in development strategy. Many development programs seek to attract new investment by reducing private sector costs, particularly the tax or regulatory costs imposed by government. ${ }^{358}$ BIDs, by contrast, operate by increasing costs on district businesses or property owners, who are required to pay assessments in addition to what they owe in municipal taxes. In theory, of course, the economic benefit of BID services offsets the cost of the assessments, so that BIDs should on balance reduce business costs. But in an era when incentives to business usually mean tax cuts, the notion that tax increases that fund improved public services might be a means of attracting and retaining business-and that many businesses apparently agree-is a striking departure.

2. Bringing the Suburban Shopping Mall Downtown. - The development of BIDs has been particularly shaped by the effort of urban downtowns to meet the challenge posed by their great nemesis-the suburban shopping mall. The BID is, in effect, an economic development device that attempts to use the special assessment and the special district structure to provide common area amenities and create a centralized management structure for business areas along the lines of a shopping mall. Sometimes competition from existing malls or a plan to open a new mall in a nearby suburban area is the immediate impetus to BID formation activities. ${ }^{359}$ More generally, the mall and its cousins the theme park and the festival marketplace are models for the kind of integrated service delivery, area-wide management, and strategic planning that downtowns believe they need if they are to survive in an era of intense interlocal competition for business investment and commercial activity. ${ }^{360}$

357. On the relationship between TIF districts and BIDs, see Briffault, Sublocal Structures, supra note 53 , at $512-14,521$.

358. The paradigmatic version of the tax cut and regulatory relief strategy of urban development is the enterprise zone. For a comparison of BIDs and enterprise zones, see id. at 509-11, 521.

359. See, e.g., Ross Farrow, Downtown Merchants Split on Sharing Tab to Attract Shoppers, Sacramento Bee, June 5, 1997, at N1; Robert W. Goodson, A BID for Downtown, Legal Times, Apr. 21, 1997, at S36.

360 . See PPS, supra note 11 , at 35 (the BID "borrows heavily from the successful experience of suburban shopping centers"); see, e.g., Bradley, supra note 1 , at 11 ("purpose for BIDs grew out of models for shopping center management"); Hudson, supra note 148, at 63 (BIDs are "modeled somewhat after shopping Center management"); Feldmann, supra note 14, at 18 (discussing plans for BID in Washington, D.C.); Hadad, supra note 56, at A13 (quoting president of International Downtown Association on downtowns "competing against shopping centers, office parks and theme parks"); Alan S. Oser, Business Improvement Districts: Banding Together for Local Betterment, N.Y. Times, Feb. 10, 1991, § 10, at 5 (Rockefeller Center as model for Grand Central BID); New 
The suburban shopping mall model has influenced BIDs in three ways. First, BIDs' focus on services rather than on the creation of new infrastructure reflects the understanding that "physical improvements alone will not enhance [d] owntown" 361 sufficiently and that, instead, "shopping center-type services" are needed to attract and retain businesses and customers. ${ }^{362}$ The hallmark of the shopping mall and the theme park is a clean, safe, orderly environment "in which the emphasis on safety and tidiness is supposed to make visitors feel secure and happy so they'll spend money and come back." 363 Paul Levy, the executive director of Philadelphia's Center City District BID, has suggested that shopping malls and theme parks are "setting higher standards" for the cleanliness and safety of public spaces. ${ }^{364}$ BIDs are created first and foremost to supply the high-quality services needed to create the sense of a clean, well-lighted place-a "'managed environment'" 365 — that malls, private office and retail complexes and theme parks have led shoppers, office workers, tourists and business investors to expect. ${ }^{366}$

Second, and consistent with the notion of a managed environment, the mall provides a model of the institutional structure for managing business areas. BIDs do more than assure that downtown receives housekeeping services. They provide a mechanism for hiring a staff of professionals who can oversee those services, consider new services and bring together downtown interests to consider and address area-wide con-

Jersey Dep't of Community Affairs, supra note 175, at 3 (BIDs create business advantages "enjoyed almost exclusively by shopping malls"); The BID Manual, supra note 93, at 5 (private developments such as the South Street Seaport and Rockefeller Center are "models looked to by many"); PDC, supra note 69, at 9 (BID "is an attempt to permit business districts to organize using the principles of shopping centers to compete in today's world").

361. National League of Cities, Accepting the Challenge: The Rebirth of America's Downtowns 8 (1994).

362. Lawrence O. Houstoun, Jr., Six Tests for State Enabling Legislation, in IDA, supra note 10, at 36 . See also PDC, supra note 69, at 4 ("Planning and management have replaced brick and mortar orientations for downtown programs.").

363. Fehr, supra note 180, at A20 (citing views of leaders of Washington, D.C.'s new downtown BID).

364. Paul R. Levy, Philly's Center City District Brings Vision to Life, Nation's Cities Wkly., Aug. 25, 1997, at 3. According to Richard Bradley, one-time President of the International Downtown Association and executive director of the Washington, D.C., BID, " $[t]$ he common area maintenance practices in suburban shopping centers and competition from these centers spurred downtowns" to create BIDs. See Williams, supra note 34 , at 1 . Williams also cites an alternative model of common management of commercial space occupied by a wide variety of independent users-the office buildingin quoting developer Donald Hunter: "'What property managers can do in their own lobbies but not up and down the street can, in fact, be done through the BID mechanism." 'Id.

365. Fehr, supra note 180, at A1 (citing views of leaders of Washington, D.C.'s new downtown BID).

366. See Zukin, supra note 23, at 65 (for both urban downtowns and suburban malls, the goal is "cleanliness, security, and visual coherence"). 
cerns. ${ }^{367}$ BID proponents repeatedly describe the BID as more than a device for providing common area amenities, important as that is, and see it instead as a "serious organizing and management tool." 368

Third, and growing out of the vision of the BID as a mall-like management device, BID proponents seek to emulate the ability of shopping center and theme park managers to engage in strategic planning for their properties. In their view, part of the success of the mall is due to the ability of a mall's management to look beyond the interests of particular shops. This includes leasing to tenants whose businesses complement each other and fit the overall themes of the mall and sponsoring special events and engaging in activities that promote the interest of the mall as a whole. ${ }^{369}$ Accordingly, they argue that urban business interests need some centralized management which can "make downtown a marketplace and not simply a collection of individual stores." 370

Like the mall and the theme park, then, the BID is intended to provide high-quality common area amenities, serve as a management structure for business-related services and engage in strategic planning. BID directors and administrators undertake long-term forecasting; ${ }^{371}$ commission market analyses; recruit businesses to enhance what the BID staffs believe is the proper mix of stores within the district; ${ }^{372}$ develop and implement design standards intended to help market the district; and sponsor special events and promotional, advertising and merchandising activities that treat the district as an economic unit. ${ }^{373}$ They lobby city hall for enactment, or more effective enforcement, of laws dealing with peddling, street vendors and sex shops, and rules dealing with noise and sidewalk

367. Paul Levy, the executive director of Philadelphia's Center City District, notes that a BID provides downtown property owners "a legal mechanism, analogous to a mall maintenance corporation.” Levy, supra note 364, at 3.

368. The BID Manual, supra note 93, at i.

369. The view that suburban malls benefit from centralized management, and urban downtowns suffer from its absence, is not limited to BID proponents. The urban sociologist William $H$. Whyte writes that downtowns need

more kinds of stores-specialty stores in particular. But the retail mix is generally a matter of happenstance, ... . with too many mismatches between stores and the market. . . Shopping mall managements do not sit and wait for good tenants to show up. They go out after them. Downtown people should do the same.

William H. Whyte, City: Rediscovering the Center 321-22 (1988). Whyte argues that cities err in "trying to compete with the shopping malls by copying the physical form of them"such as enclosure within one large climate-controlled structure. "What they should be copying is the centralized managements of them: their ability to coordinate tenant selection, promotion, leasing, and market research.” Id. at 323.

370. PPS, supra note 11 , at 35 .

371. See, e.g., Kevin Diaz, Minneapolis Maps Out Downtown's Future, The Star Trib., Dec. 22, 1996, at B1 (15-year plan for Minneapolis calls for expansion of downtown business improvement districts: "[I]f downtown is going to face down the competition for people, it needs a unified strategy, just as suburban mall merchants market themselves jointly.").

372. See, e.g., Rothstein, supra note 248 , at B6.

373. See, e.g., Hudson, supra note 148, at 63 . 
obstructions. New York's Grand Central BID employs " 'the services of a retail designer, a leasing specialist, and a zoning and enforcement specialist to work with retailers to improve their visual impact on the [D] istrict and to ensure that their presentation complies with applicable City code provisions." "374

The example of the shopping mall and the theme park drives many BIDs to seek a distinguishing look. They dress their sanitation and security workers and "goodwill ambassadors" in distinctive uniforms, hang banners sporting the BID name and logo, and adopt design criteria for street signs, street lighting, benches, trash receptacles and other street furniture. A BID may attempt to persuade businesses and landowners to abide by common rules governing store signs, awnings, security grates and window displays that are consistent with the district's marketing strategies, ${ }^{375}$ or arrange for loans to enable firms within the districts to bring their storefronts into compliance with BID design criteria. ${ }^{376}$ Some have persuaded landowners to take the BID's interests-as determined by BID directors and managers-into account in decisions concerning the use of privately owned land. ${ }^{377}$

The model of centralized downtown management also exercises an influence over BID programs. Although much of the concern about BIDs as a device for privatizing the public sector focuses on their provision of traditional municipal services, particularly security, sanitation and street maintenance, and on their forays into social services, the trajectory of BID development appears to be away from "public" services and more towards serving as an institutional structure for the downtown business community in the manner of a private shopping mall, office building owner or real estate asset manager. ${ }^{378}$

BIDs are not alone in looking to the shopping mall and the theme park as models. As the architecture critic Paul Goldberger has noted, many contemporary cities promote designs and specific projects-performing arts centers, festival marketplaces, enclosed shopping, hotel and office spaces-that create urban centers suffused with suburban values.

374. Kessler v. Grand Cent. Dist. Mgmt. Ass'n, 960 F. Supp. 760, 765 (S.D.N.Y. 1997) (quoting Joint Stipulation of Parties, Ex. P at 11).

375. See, e.g., Jacobs, supra note 252, at 4 (8th Street BID "drafted uniformed signage guidelines" and seeks to ban solid steel roll-down gates).

376. See, e.g., Davis, supra note 255, $\S 1$, at 5 (Center City District arranging belowmarket-rate loans for firms willing to make storefront improvements recommended by the BID).

377. See, e.g., Sussman, supra note 258, at 1 (BID coerced realtor to close down a Kentucky Fried Chicken franchise, which was replaced by a public plaza).

378. New Jersey Dep't of Community Affairs, supra note 175, at 3 . Not all businesses want such management. One commentator complains that "[i]ndependent store owners cringe at hearing words like organization, management and assessment. . . . In all communities, a core of recalcitrants must always be fought, but the reason for creating a B.I.D. is to insure that if a working majority of downtown business people want action, a minority can't squelch it." Zacharias, supra note 176, at 39 . 
The success of the shopping mall/theme park model "stands as proof that our culture has not discarded the most important urban value of all, the desire for physical proximity to others in a shared place."379 People want the attractive features of urban life- "energy, variety, visual stimulation, cultural opportunities, the fruits of a consumerist culture"-if they can obtain them in a clean, safe, controlled environment, and without the crime and poverty characteristic of traditional urban settings. ${ }^{380}$ The rise of the mall/theme park model underscores both the importance of basic services, like security and sanitation, to the success of urban areas, and the danger that the pursuit of these values can undermine the openness, spontaneity, and diversity that have been the hallmarks of traditional urban life. Even as he criticizes the "sealed-off, private" nature of contemporary mall-based urban development, Goldberger ruefully acknowledges that "the traditional, dense, truly urban city" may have little choice if it is to survive "in the face of competition from out-towns, suburbs and suburbanized cities in which disengagement is valued above engagement." 381

The shopping center model emphasizes the "private" side of BIDsthe desire on the part of BID proponents and managers to emulate a distinctly private institution. But BIDs are not shopping malls or theme parks. Physically, most operate in open-air environments-public streets and sidewalks, public parks and squares-which are not physically enclosed and which may not be closed off to the general public. BIDs do not own the property in their districts, they do not charge admission to their districts, and they do not limit physical access to paying customers. They may outfit their employees in distinctive uniforms, and they may implement design criteria for public property in the districts, but they generally lack the power to impose those standards on private landowners, to review the leasing decisions of landowners, or to otherwise control land uses within their districts. BIDs may lobby city hall for new regulations and they may jawbone private landowners concerning their leasing and design decisions. But ultimately lacking both the police power and the power that comes from property ownership, they are dependent on either municipal government action or voluntary landowner compliance to achieve their goals.

Other sections of this Article have demonstrated how BIDs combine both public and private elements. The shopping mall model points out how BIDs lack some of the key attributes of both public and private sectors.

379. See Paul Goldberger, The Rise of the Private City, in Breaking Away: The Future of Cities, Essays in Memory of Robert F. Wagner, Jr. 141 (Julia Vitullo-Martin ed., 1996).

380. Id. at $136-37$.

381. Id. at 140 . 


\section{BIDs in Court: Federal and State Constitutional Issues in BID Governance AND Finances}

A BID can be seen as a deal between a municipal government and business district property owners or firms. The property owners or businesses agree to pay extra taxes. In return, the city lets them use the money raised by those taxes to finance supplemental services for the district. The BID advisory board or management committee provides a structure which assures that BID property or business interests control the expenditure of those funds. ${ }^{382}$

Two aspects of this deal may be subject to constitutional attack. First, by assuring landowner or business control of BID boards, state enabling legislation may violate the one person, one vote doctrine of the federal Equal Protection Clause. ${ }^{383}$ The one person, one vote question is both a challenging legal issue and a metaphor for the broader concern about the undemocratic nature of BID governance. The Supreme Court has applied one person, one vote to local governments but has also exempted certain special districts from the requirement. ${ }^{384}$ The Court's doctrine in this area is murky, and the BIDs' distinctive combination of public and private elements is in tension with the Supreme Court's analytic framework. If one person, one vote applies, then states will either have to fully enfranchise district residents in BID elections or shift control over BID management to elected city governments. Either result could undermine the willingness of property owners or businesses to support BIDs. If one person, one vote does not apply, other mechanisms are needed to assure the democratic accountability of BIDs.

Second, BID assessments may run afoul of state constitutional rules limiting taxation. Most states exempt assessments from restrictions on local taxes, but it is not clear whether BID assessments should be treated like ordinary assessments or, instead, like taxes. If BID assessments are

382. In those states where there is no mechanism through which owners or firms may give or withhold their consent, there is no formal deal. Moreover, since BIDs bind district owners or businesses who opposed the district's creation, the business or property side of the deal must refer to business or property interests collectively rather than to every single firm or owner.

383. Related to the one person, one vote issue is the question of whether the formation of a BID implicates the right to vote protected by the federal Voting Rights Act. Claiming that the process that culminated in the approval of a Jackson, Mississippi BID constituted a change in the state's election procedures, five local voters challenged the state's failure to obtain Justice Department preclearance of the formation of the BID, which would be required under section five of the Voting Rights Act if the district-level election that authorized the BID involved "voting" within the meaning of the Voting Rights Act. In an unpublished decision, a federal district court dismissed the case for lack of standing and the Supreme Court summarily affirmed. See Parker-Weaver v. Fordice, $119 \mathrm{~S}$. Ct. 791 (1999), aff'g mem., Parker-Weaver v. Fordice (S.D. Miss. 1998) (unpublished). See text accompanying notes 77-81, supra, for a description of Mississippi's BID formation law.

384. See generally Briffault, Who Rules at Home?, supra note 50 (examining the extension of federal constitutional protection of the right to vote to the local level). 
subject to state tax rules, some BIDs would be put out of business. ${ }^{385}$ In addition, BID assessments produce intra-local differences in the level of property taxation which, in turn, lead to variations among city neighborhoods in the quantity or quality of public services. Like one person, one vote, the legal status of BID assessments is intertwined with a broader policy issue-whether BIDs foster undesirable inequities in the treatment of different neighborhoods.

\section{A. One Person, One Vote and the Election of BID Governing Boards}

It is quite fitting that the leading decision concerning the constitutionality of BID voting rules should involve New York's Grand Central BID. ${ }^{386}$ Collecting $\$ 9,705,000$ in assessments in fiscal 1997,387 the Grand Central BID has the largest assessment base of any BID in the United States. Stretching between 35th Street and 54th Street, and between First and Fifth Avenues, in midtown Manhattan, the BID encompasses approximately seventy-one million square feet of commercial space, or approximately nineteen percent of Manhattan's total office space. ${ }^{388}$ Approximately 250,000 people work in the district although fewer than a thousand people live there. ${ }^{389}$ The BID has undertaken an extensive program of security, sanitation, social services and assistance to business, as well as an ambitious capital program of street improvements. It has been a leader on issues of urban design and public amenities, installing hundreds of benches, bicycle racks, news racks, street signs, directions for tourist destinations, planters and trees. ${ }^{390}$

Grand Central is not only the largest BID in the country; it has been the most controversial. ${ }^{391}$ Its debt-financed capital program was an early source of city concern. ${ }^{392}$ As noted in Part I, in 1995 the BID was em-

385. Treating BID assessments as taxes for some purposes would not always be fatal to BIDs. BIDs have flourished in New York even though the state's BID legislation imposes a cap, comparable to the ceiling on real property taxes, on BID assessments. See N.Y. Gen. Mun. L. $§ 980-k$ (b) (McKinney Supp. 1999).

386. See Kessler v. Grand Cent. Dist. Mgmt. Ass'n, 158 F.3d 92 (2d Cir. 1998).

387. See NY COM, supra note 2, at 41. Including funds from a bond issue, grants, contributions, private contracts and service fees, the Grand Central District Management Association had an income of over $\$ 12$ million in fiscal 1995. See Kessler, 158 F.3d at 112. By fiscal 1996, that had risen to $\$ 14.3$ million.

388. See Kessler, 158 F.3d at 95.

389. See Kessler v. Grand Cent. Dist. Mgmt. Ass'n, 960 F. Supp. 760, 774-75 (S.D.N.Y. 1997).

390. See David W. Dunlap, Street Furniture Designs Stuck in Gridlock, N.Y. Times, Aug. 9, 1998, § 11, at 16 .

391. See Bruce Lambert, After Rapid Growth, B.I.D.s Enter a Time of Turmoil, N.Y. Times, Dec. 31, 1995, $\S 13$, at 6 (describing Grand Central as "the lightning rod for the anti-B.I.D. sentiment”). For critical treatments of the Grand Central BID, see Cities Within Cities, supra note 181, at 86-93; Managing the Micropolis, supra note 96, at 32-39; Barr, supra note 9, at 399-404; Kennedy, supra note 7, at 314-24. For more positive accounts, see Kelling \& Coles, supra note 35, at 113-14; MacDonald, supra note 13, at 33-41.

392. See Feiden, supra note 27 , at 1 . 
broiled in a contretemps, which eventually cost it a half-million-dollar federal grant, over inappropriately mingling security and social service functions in its homeless outreach program. ${ }^{393}$ A federal district court subsequently found that the BID's use of formerly homeless and jobless people, who were paid a "training" stipend rather than the minimum wage, to perform a variety of clerical, administrative, maintenance, food service and outreach work in its homeless services program violated the Fair Labor Standards Act and New York's minimum wage law. ${ }^{394}$ Its internal management practices were sharply criticized by a City Comptroller's audit. ${ }^{395}$ The BID's management, known as the Grand Central Partnership, also manages two other large midtown BIDs-34th Street and Bryant Park-thereby creating the impression that the BID wields undue power. ${ }^{396}$ The BID's management often stressed its private nature, ${ }^{397}$ and appeared to purposely push the envelope of independence from public control.

New York law requires a majority of the seats on the board of directors of a BID's district management association to be reserved for property owner representatives. ${ }^{398}$ Residents of the Grand Central BID alleged that the disproportionate representation of property owners on the Grand Central District Management Association ("GCDMA") board vio-

393. See James Traub, Street Fight, The New Yorker, Sept. 4, 1996, at 36. 1998).

394. See Archie v. Grand Cent. Partnership, Inc., 997 F. Supp. 504, 524-36 (S.D.N.Y.

395. Comptroller's Audit, supra note 159, at 19-35.

396. See Vivian S. Toy, Further Restraint Is Sought For Improvement Districts, N.Y. Times, Nov. 12, 1997, at B3. Grand Central's executive director, Daniel Biederman, also managed the other two BIDs and was sometimes known as the "Mayor of Midtown." See Greg Sargent, Midtown Has One Mayor: Rudy Wins Showdown With Daniel Biederman, N.Y. Observer, Sept. 28, 1998, at 1. Commentators and public officials appear to have been particularly galled by the fact that Biederman received three separate salaries which together exceeded the compensation paid the mayor. See BID's Blind Faith in Dan Biederman, Crain's N.Y. Bus., Aug. 3, 1998, at 8; David Firestone, An Admirer of Giuliani Feels His Wrath, N.Y. Times, July 31, 1998, at B6.

397. See, e.g., Manshel, supra note 24, at 106 ("The essential theory of the BID program ... lies in allowing a private entity the freedom ... [to] supplement traditional governmental activities in new ways. BIDs, ... were intended to function independently of government."). Grand Central's management criticized the City Comptroller's "unwillingness to recognize that these new vehicles for urban redevelopment (BIDs) should operate more like private companies than government agencies." Comptroller's Audit, supra note 159, at 58 .

398. Commercial and residential tenants and, in New York City, four municipal officials are also guaranteed representation on the board. The owner and tenant members are elected in "class" votes: Commercial tenants elect the commercial tenant representative(s); residential tenants elect their representative(s); and property owners elect their representatives. A BID board may adopt a by-law that weights the votes of property owners, in proportion to the assessments levied against their properties, in the election of board members. Even with property-weighted voting, no owner may control more than one-third of the property owner vote. See N.Y. Gen. Mun. Law $\S 980-m$ (McKinney Supp. 1999). 
lated the one person, one vote doctrine. ${ }^{399}$ On cross-motions for summary judgment, the federal district court for the Southern District of New York dismissed the residents' claim. ${ }^{400}$ One and a half years later, a divided Second Circuit affirmed. ${ }^{401}$ In an opinion by Judge Kearse, the court found that due to the district's "limited purpose," "[l]ack of [s]overeign [p]ower," and "[1]imited [r]ole and [r]esponsibility," 402 the "City's [c] ontrol [o]ver GCDMA," 403 and the "disproportionate effect" the BID had on property owners, ${ }^{404}$ the BID fell within the special district exception to one person, one vote. As a result, the state could constitutionally mandate a property owner majority on the BID board. ${ }^{405}$

Kessler's claims that the Grand Central BID has a "limited purpose," "limited role and effect," and "disproportionate effect" on property owners reflect the Second Circuit's effort to fit the case to the Supreme Court's local government jurisprudence. ${ }^{406}$ Kessler's findings, however, are difficult to square with the BID's powers and its potential impact on district residents. The "lack of sovereign power" and "city control" arguments better describe the differences between BIDs and the local units that have been held subject to one person, one vote, and provide a more satisfactory justification for exempting BIDs from one person, one vote, but they raise empirical and theoretical problems of their own. ${ }^{407}$

399. At the time of the suit, the Grand Central BID board consisted of 31 members representing property owners, 16 representing commercial tenants, and 1 representing residential tenants, in addition to the 4 public members. The Grand Central BID also provided for assessment-weighted voting for property owners. See Kessler v. Grand Cent. Dist. Mgmt. Ass'n, 960 F. Supp. 760, 766 (S.D.N.Y. 1997).

400. See id. at 763. The district court considered and rejected arguments that the plaintiffs lacked standing and that the action was not ripe. Plaintiffs, who resided in cooperative apartments, were shareholders of the cooperatives, and thus arguably property owners. Citing New York state cases dealing with cooperative shareholders, however, the court viewed the plaintiffs as more akin to tenants than property owners and rejected the argument that they lacked standing. See id. at 768. Defendants argued the suit was not ripe because plaintiffs had never attempted to gain a majority of seats on the Grand Central board. As such an attempt would have been barred by the board's by-laws and by city and state laws, the court easily rejected the ripeness argument. See id. at 769-70.

401. See Kessler v. Grand Cent. Dist. Mgmt. Ass'n, 158 F.3d 92 (2d Cir. 1998). Judge Kearse was joined by Judge Walker. Judge Weinstein, sitting by designation, dissented.

402. Id. at 104-05.

403. Id. at 106.

404. Id. at 98 .

405. Implicitly, the Second Circuit assumed that the district managing board, although formally a private not-for-profit corporation, is a state actor subject to constitutional requirements. Only the district court expressly addressed the state action question, noting that "[a]lthough GCDMA is a private entity, state law provides for its establishment and operation, and GCDMA operates pursuant to its contract with the City." Thus, the board is "a state actor for purposes of the Equal Protection Clause." Kessler, 960 F. Supp. at 766 n.7. The Second Circuit never considered the issue and assumed throughout that GCDMA board elections were subject to the Equal Protection Clause.

406. Kessler, 158 F.3d at 104.

407. Id. 
Kessler was shaped by the Supreme Court's efforts to apply the one person, one vote to the messy arrangements of local governance. Unlike the states, local government is characterized by fragmentation, specialization, and overlap. Many places fall within the jurisdiction of two or more localities, and many local units exercise limited authority or have power over a narrow set of activities. In Avery $v$. Midland County, ${ }^{408}$ the very case in which the Supreme Court first held that one person, one vote applies to local governments, the Court also indicated that "a special-purpose unit of government assigned the performance of functions affecting definable groups of constituents more than other constituents" might be exempt from the rule. ${ }^{409}$ The Court insisted that one person, one vote was not a "uniform straitjacket" intended to prevent "mechanisms of local government suitable for local needs and efficient in solving local problems." 410

In Avery, the Court rejected the argument that due to the greater impact a county government had over rural areas-the urban area within the county had its own city government and was governed primarily by that city-rural residents could be given a disproportionately large voice on the county governing board. Instead, the Court found that since the county could exercise "general governmental powers over the entire geographic area served by the body," county government elections were subject to one person, one vote. ${ }^{411}$ Avery indicated that all cities and counties are subject to one person, one vote, and shortly thereafter the Court held that one person, one vote applies to special purpose districts as well. Leaving open the possibility that "there might be some case in which a State elects certain functionaries whose duties are so far removed from normal governmental activities ... that a popular election in compliance with [one person, one vote] might not be required," 412 the Court concluded that neither a local school board ${ }^{413}$ nor a regional junior college district ${ }^{414}$ fell into that category.

Subsequently, in two cases involving water districts that finance and operate capital facilities, the Court found that a state could limit the franchise to landowners, and, indeed, could allocate votes according to assessed valuation. In Salyer Land Co. v. Tulare Lake Basin Water Storage District, ${ }^{415}$ the Court upheld a California law that limited to landowners the right to vote in elections for the governing board of a water storage district. The district, which undertook water projects and stored and distributed water for agricultural purposes, was financed by assessments

408. 390 U.S. 474 (1968).

409. Id. at $483-84$.

410. Id. at 485 .

411. Id.

412. Hadley v. Junior College Dist., 397 U.S. 50, 56 (1970).

413. See Kramer v. Union Free Sch. Dist. No. 15, 395 U.S. 621 (1969).

414. See Hadley, 397 U.S. at 53-54.

415. 410 U.S. 719,745 (1973). 
against landowners and by charges for water sold to landowners. The Court determined that the water storage district "by reason of its special limited purpose and of the disproportionate effect of its activities on landowners as a group" was not subject to one person, one vote. ${ }^{416}$ In Ball $v$. James, ${ }^{417}$ the Court held that one person, one vote did not apply to elections to the governing board of a water reclamation district. In addition to storing and delivering water to landowners, the district generated and sold electric power. Most of its power customers were not landowners, and most of its revenues came from power sales. Nevertheless, the Court held that the district was a special, limited purpose district and that landowners were so disproportionately affected by its activities that the franchise in district elections could be limited to them. ${ }^{418}$

Salyer and Ball articulate a two-pronged test, echoed by the Second Circuit in Kessler, for determining whether a local government body is exempt from one person, one vote, the test: Does the government serve a "special limited purpose", and does it "disproportionately" affect those who are enfranchised? 419

Taking the second prong first, it is certainly true, as the Second Circuit found, that the Grand Central BID, like most BIDs, is financed largely by assessments paid by property owners. Indeed, property owners play a greater role in financing the BID than they did in financing the water district in Ball, since the water district received more revenue from purchasers of electric power than from assessments paid by property owners. ${ }^{420}$ But that does not mean that property owners are disproportionally affected by the BID. Landowners may be able to pass along at least part of the cost of BID assessments to their tenants. If BID activities cause property values to rise in the district relative to the city as a whole, landowners at some point ought to be able to charge their tenants a higher

416. Id. at 728. The landowner voting rule was reviewed under the more relaxed rational basis test and was easily sustained. See also Associated Enters. v. Toltec Watershed Improvement Dist., 410 U.S. 743 (1973) (upholding similar landowner voting rule in Wyoming under rational basis test).

417. 451 U.S. 355 (1981).

418. Id. at $370-71$.

419. Ball, 451 U.S. at 363; Salyer, 410 U.S. at 720-21.

420. Although landowners supplied only a small fraction of the district's revenues, they were "the only residents of the District whose lands are subject to liens to secure District bonds" and the only ones subject to the district's power to levy acreage-based taxes. Ball, 451 U.S. at 370. 
rent. ${ }^{421}$ Indeed, in City of Phoenix v. Kolodziejski, ${ }^{422}$ the Supreme Court invalidated state laws limiting the vote on local bond issues to local property taxpayers in part because "a significant part of the ultimate burden" would be passed along by residential property owners to their tenants and by commercial property owners to residents in the price of goods and services. ${ }^{423}$ Although the timing and extent of the ability of landowners to pass through BID assessments is unclear, at least some portion of BID costs is probably borne by BID tenants.

Nor does a BID make its impact felt solely through the imposition of assessments. The services financed by BID assessments also affect both property owners and non-owners. The Supreme Court employed a similar analysis in finding that the vote on local bond issues, which concerned the financing of public facilities, could not be limited to taxpayers. ${ }^{424}$ BID policing strategies, social service programs, street maintenance and repairs and economic development activities can have a direct impact on district residents and on the quality of life in the district. ${ }^{425}$

To be sure, Kessler's analysis of "disproportionate effect" precisely tracks the approach the Supreme Court took in Salyer and Ball. The problem is not with the Second Circuit but with the Supreme Court. Kessler simply highlights the fact that in some one person, one vote cases, the Supreme Court assumed that the costs and benefits of a local district are widely diffused throughout the community, while in other cases, the Court evaluated a district's "effect" entirely in terms of who is subject to district assessment. The "disproportionate impact" prong of Salyer and $\mathrm{Ball}$, thus, is less a tool of analysis and more a rhetorical flourish ap-

421. Judge Kearse's opinion noted that any rent increases "will be limited by factors such as rental market conditions, the terms of individual leases, or City and State rent control and rent stabilization regulations." Kessler v. Grand Cent. Dist. Mgmt. Ass'n, 158 F.3d 92, 107 (2d Cir. 1998). That may be true, but ultimately BID assessments, as a component of landowner costs, affect the price that tenants pay for renting space in the district. See also Managing the Micropolis, supra note 96, at 17 (property owners may support BIDs "because the assessment can be passed along to the commercial tenant"). The real question, in terms of plaintiffs' one person, one vote claim, is whether residents may be burdened by BID assessments. In most BIDs, assessments are imposed only on commercial property, so that even if the landowners are able to pass the assessments along, those costs affect only commercial tenants, not residential tenants. In those situations, landowners may not bear the whole financial burden but residents bear no burden at all. In Kessler, however, the Grand Central BID assessed residential as well as commercial property, so to the extent that assessments were passed along in cooperative maintenance charges, residents bore a share of the costs of district operations.

422. 399 U.S. 204 (1970).

423. Id. at $210-11$.

424. See id. at 206 (discussing Cipriano v. City of Houma, 395 U.S. 701, 702 (1969)).

425. See Kramer v. Union Free Sch. Dist. No. 15, 395 U.S. 621, 632 (1969) (for purposes of one person, one vote analysis, parents and taxpayers are not "primarily affected" by elections to a school board that operates public schools financed in part from local tax payments). 
pended to the principal question of whether the district has a "special limited purpose." 426

Salyer and Ball focused on whether a district undertook "normal functions of government," which Ball defined as including "the maintenance of streets, the operation of schools, or sanitation, health, or welfare services." 427 BIDs engage in most of these activities, other than the operation of schools. The Grand Central BID, in particular, provides security, sanitation, street maintenance and social welfare services. ${ }^{428}$ These are the classic activities of urban government.

Moreover, the Salyer-Ball exemption reflects the Supreme Court's view that the water districts in those cases were of a "nominal public character." Although technically public, they were "essentially business enterprises" created to provide water and power services akin to those provided by private utilities. ${ }^{429}$ A BID, however, is not a proprietary enterprise that delivers goods or services to individual landowners for a fee directly measured by the amount of the good or service supplied. The amount of street patrolling or sidewalk cleaning a property owner receives from a BID does not depend on the size of the assessment. Rather, the BID provides these services to the district as a whole. So, too, the benefit an individual property owner may enjoy from BID-sponsored street fairs, marketing campaigns, and business recruitment efforts may have little or no relationship to its particular assessment. A BID is created to serve the interests of landowners, ${ }^{430}$ but it acts less like a private enterprise that serves individual clients for a fee and more like a government that provides area-wide services financed out of area-wide charges.

Judge Kearse, writing for the majority, determined that Grand Central had a "[l]imited [r]ole and [r]esponsibility," ${ }^{311}$ despite its provision of security, sanitation and social services, because the BID was not the sole or even the primary provider of these services in the district. BID security and sanitation-the most "municipal" of BID activities-were entirely supplemental to policing and trash collection provided by the city. ${ }^{432}$ But this will often be the case when two local governments, such

426. Ball, 451 U.S. at 363 ; Salyer, 410 U.S. at 720-21. For a fuller statement of my argument that the disproportionate effect test is circular, see Briffault, Who Rules at Home?, supra note 50 , at $370-71$.

427. Ball, 451 U.S. at 366 .

428. See Kessler v. Grand Cent. Dist. Mgmt. Ass'n, 158 F.3d 92, 95 (2d Cir. 1998).

429. Ball, 451 U.S. at 368.

430. The Kessler majority's first argument in support of the exemption of the GCDMA from one person, one vote is that although the Grand Central BID has undertaken many complex problems, its purpose-the promotion of business-is a limited purpose. See Kessler, 158 F.3d at 104. As Judge Weinstein noted in dissent, however, "[t]he phrase 'promotion of business' is too amorphous to provide any substantive limitation on the BID's activities." Id. at 126 . BIDs do not promote business simply by providing services to business. Rather, like a municipal government, they promote business, in part, by improving the public environment in which business operates.

431. Kessler, 158 F.3d at 113.

432. Id. 
as a city and a county, operate in the same jurisdiction. Avery clearly rejected the argument that where urban residents are fully enfranchised in the election of the city government that is their principal local service provider, they are not entitled to equal voting rights in the election of the county government which also has jurisdiction over them. Rather, Avery indicates that when more than one local government unit engages in "normal government functions" in the same area, one person, one vote presumptively applies to each such unit.

Salyer and Ball implicitly rely on the application of a public/private distinction to the services undertaken by special district governments. Such a distinction is analytically unsound since virtually all local government services could be provided by both public and private entities. The Supreme Court, in Salyer and Ball, denied the public nature of water storage and delivery. But given the existence of more than three thousand local governments specially created to undertake water management functions, it is difficult to say that such a widespread governmental activity is not a normal function of government. ${ }^{433}$ Conversely, as the existence of private security forces, private carting services and private schools demonstrates, many classic government functions may also be discharged by private enterprises. If the Salyer-Ball analysis is applied to BID services, then BIDs ought to be placed on the public, not the private, side of the line. But the very attempt to classify governments along a public/private continuum according to the nature of the services they provide lacks analytical rigor and leads to arbitrary results.

Yet, BIDs do differ from the local governments that have hitherto been subject to one person, one vote. The difference is suggested by Kessler's invocation of the Grand Central BID's "lack of sovereign power" 434 and its subjection to city control. 435 Unlike cities, counties and many special districts, particularly school districts, governed by one person, one vote, BIDs lack the authority to tax, they lack the authority to make laws and they generally lack the authority to regulate private behavior. They may undertake traditional governmental services, but they have relatively limited authority over those services. BIDs may undertake policing, but they have no power to criminalize behavior or to perform such typical law enforcement functions as making arrests, conducting investigations or obtaining search warrants. ${ }^{436}$ They provide trash collection services but they have no power to regulate the disposal of waste products, to conduct health and safety inspections or even to issue citations for violations of city codes. ${ }^{437}$

433. See Briffault, Who Rules at Home?, supra note 50 , at 374 , nn.137-138.

434. Kessler, 158 F.3d at 104.

435. These concerns were central to Judge Scheindlin's analysis in her opinion for the district court. See Kessler v. Grand Cent. Dist. Mgmt. Ass'n, 960 F. Supp. 760, 773 (S.D.N.Y. 1997).

436. See Kessler, 158 F.3d at 105.

437. See id. at 104 . 
Moreover, BIDs are subject to considerable municipal control. They can undertake only those activities authorized by the district service plan approved by the city, and their expenditures are limited by the district plan as well. Additional improvements or services, increases in district spending or changes in the method of assessment require the approval of the city government. ${ }^{438}$ New York City BID contracts for improvements, goods, and services are "subject to all applicable provisions of the law relating to the letting of contracts by the municipality." 439 BIDs must file annual reports with the Department of Business Services ("DBS") and submit to audits by an Audit Committee set up under the City Charter ${ }^{440}$ The city, not the BID, levies and collects the BID's assessments. ${ }^{441}$ The city determines whether a BID may issue debt. Representatives of city officials sit on the BID's managing board. Indeed, the district managing authority's power to manage the BID derives entirely from a contract which builds in a structure of city oversight and which is subject to nonrenewal upon expiration.

BIDs are public bodies, providing traditional municipal services, but they are relatively junior public bodies. To borrow the language, albeit not the analysis, of Salyer and Ball, they are "special limited purpose districts" not because the services they offer are not traditional public services but because BID boards have so little policymaking authority with respect to those services. Their authority over the citizenry is so narrow, and their autonomy relative to city government is so constrained, that they do not "govern" in any meaningful sense. ${ }^{442}$

438. See N.Y. Gen. Mun. Law $\S 980-$ i (McKinney Supp. 1999).

439. Id. § 980-1.

440. See Manshel, supra note 24, at 105.

441. Under New York law, the BID's assessments are counted against the state constitutional ceiling on municipal taxes, and any BID debt is counted against the state constitutional ceiling on municipal debt. See N.Y. Gen. Mun. Law §980-k (McKinney Supp. 1999).

442. Unlike the BID managing board which depends on the city to impose the assessment and provide the revenue which funds BID operations, the school district in Kramer had the power to force the villages within the district to raise taxes, and the district board had "significant control over the administration of local school district affairs . . . including prescribing the courses of study, [and] determining the textbooks to be used ..." Kramer v. Union Free Sch. Dist., 395 U.S. 621, 623-24 (1969). Similarly, the junior college board in Hadley had the power to levy and collect taxes, issue bonds, hire and fire teachers, supervise and discipline students "and in general manage the operations of the junior college." Hadley v. Junior College Dist., 397 U.S. 50,53 (1970). Compare Fumarolo v. Chicago Bd. of Educ., 566 N.E.2d 1283, 1295-98 (Ill. 1990) (neighborhood school councils with authority to hire and evaluate the principal, recommend textbooks and disciplinary and attendance policies, evaluate teaching resources and review principal's expenditure plans held to have "broad, important, and general . . . powers" over local school operations and thus subject to one person, one vote) with Pittman v. Chicago Bd. of Educ., 64 F.3d 1098, 1102-03 (7th Cir. 1995) (discussing amended law giving school councils no power, direct or indirect, to tax, limiting authority to select local principal and to "determine school expenditures . . . within budgetary limits set by the [city] board of education" is not subject to one person, one vote). See also Hellebust v. Brownback, 42 
This analysis may be subject to challenge on both empirical and theoretical grounds. First, as an empirical matter, it can be argued that BIDs have considerable autonomy in practice. ${ }^{443}$ Although the city government plays a central role in the process of BID formation, the city's involvement often drops off sharply once the BID is in operation. ${ }^{444}$ The Finance Committee of the New York City Council sharply criticized the lack of effective oversight by DBS, the city agency responsible for supervising the BIDs. Although city representatives sit on the BID boards, a tiny handful of DBS staffers are stretched thin representing the mayor on the boards of all forty BIDs in operation as well as working with sponsor groups seeking to create additional BIDs. ${ }^{445}$ Most of the reports BIDs must file with city monitors address BID finances, not the effect of BIDs on the nonowner interests in their districts. The extensive report on the Grand Central BID conducted by the New York City Comptroller focused entirely on the adequacy of BID internal management controls and compliance with state and city laws and regulations, not on BID policies or decisions concerning BID services. ${ }^{446}$

F.3d 1331, 1332-35 (8th Cir. 1994) (elected state board of agriculture, with powers to regulate and to enforce state laws concerning meat and dairy products, pesticides, the use and diversion of water and weights and measures used by commercial enterprises, had such broad regulatory authority as to trigger the application of one person, one vote).

443. See Kessler v. Grand Cent. Dist. Mgmt. Ass'n, 158 F.3d 92, 128-29 (2d Cir. 1998) (Weinstein, J., dissenting).

444. According to the City Council, " $[w]$ hile there is tremendous interaction between ... DBS and the BIDs during the approval process, the Administration has failed to allocate the sufficient resources needed for DBS to conduct effective oversight of ongoing BID activity." Cities Within Cities, supra note 181, at iv-v.

445. As the Report noted, DBS is "hampered by staffing limitations," with one assistant commissioner and just two full-time staff members, supplemented with part-time support from other staffers, required to "speak to each BID on a weekly basis, attend BID meetings, monitor BID budgets, and provide guidance to any BID going through the establishment process." Id. at 99. In a February 25, 1997 interview, Assistant Commissioner of Business Services Barbara Wolff advised me that fewer than five full-time equivalent city employees in the Department of Business Services are charged with the responsibility of both working with BID sponsors to develop new BIDs and overseeing the forty BIDs currently in existence. Interview with Barbara Wolff, Assistant Commissioner of Business Services, in New York, N.Y. (Feb. 25, 1997).

446. The Comptroller's Audit spent three pages summarizing the BID's accomplishments and more than thirty pages on the BID's "weaknesses in corporate governance," inadequate internal audit procedures, and failure to comply with New York City's contract procurement requirements. See Comptroller's Audit, supra note 395, at 14-16 (BID accomplishments); 19-35 (weaknesses in corporate governance); 41-50 (noncompliance with City procurement rules); 54-55 (need for an internal auditor). The City Council staff report also focused primarily on the BIDs' compliance with legal requirements, BID management conflicts, and the quality of BID services for property owners and businesses, but gave little attention to the impact of BIDs on nonowner residents. See Cities Within Cities, supra note 181, at 16-93. Apart from its discussion of the Grand Central homeless services controversy, the Council report was largely concerned with whether property owners were getting their money's worth from BID operations. See id. at 85-93. 
BIDs lack "sovereign power," ${ }^{447}$ but, as Judge Weinstein contended in his Kessler dissent, they do enjoy considerable discretion in carrying out the activities authorized by the district service plan. ${ }^{448}$ For the most part, BIDs formulate their own programs, which they then persuade the city to authorize. BIDs also seek to influence city policies and services. The Grand Central BID describes as part of its mission the deployment of "team specialists [who] monitor and pursue action against undesirable uses (e.g., pornography), illegal street vending, and illegal practices like oversized signs and bogus 'going out of business' sales." 449 "Pursue action" typically means pressuring the city government to take action. ${ }^{450}$ The BID also sought more vigorous enforcement of rules that would exclude sidewalk food vendors from the district. ${ }^{451}$ The Times Square BID has trumpeted its "advocacy" role in pressing for city regulation of sexoriented adult-use establishments in that district. ${ }^{452}$

BID assessments are levied and collected by the city, but the steady income from the assessments is, in practice, a source of autonomy. The funds enable BIDs to hire professional staff to plan the future development of the districts, formulate and implement design criteria, and lobby for the districts' interests with the city government. As a result, BIDs can undertake initiatives that affect the overall appearance and quality of life in their districts even in the absence of the power to directly tax and regulate district residents. The BID's vision of the district's appearance and development may be at odds with the views of other community orga-

447. The Second Circuit's use of the phrase "sovereign power," see 158 F.3d at 104-05, to distinguish BIDs from cities, counties and special districts subject to one person, one vote was an unfortunate mistake. It is a truism of local government law that no local government has sovereign power. As a matter of federal constitutional law, all local governments are technically creatures of their states, enjoying delegated power, and subject to the authority of the state to amend or abolish local powers and the localities themselves. Even in those states which have conferred home rule power on local governments, those localities are not "sovereign." What I suspect the Court meant, and what I believe is a better description of local powers, is that localities like cities enjoy broad policymaking autonomy, including the power to adopt taxes, make laws and regulate behavior within their jurisdictions.

448. See 158 F.3d at 115-16, 124-30.

449. NY COM, supra note 2 , at 41 .

450. The 34th Street BID-which shares management with the Grand Central BIDsued New York City to compel it to enforce municipal regulations against oversized and unlicensed newsstands. See 34th St. BID Sues Over Newsstand, 39 Real Est. Wkly., Feb. 24, 1993, at 5B. For another instance of litigation between a BID and its parent local government, see Mary Cummings, Coalition and Builder Battle in Riverhead, N.Y. Times, Apr. 12, 1998, § 14 (Long Island), at 1 (in dispute over proposed new mall on outskirts of Riverhead, Long Island, at one point the Riverhead BID sued the town challenging the process by which it had approved the mall).

451. See Kennedy, supra note 7, at 318. Farther downtown, the Village Alliance BID pressed for the removal of "junk peddlers" from the East Village's Astor Place. Andrew Jacobs, Kaleidoscopic Astor Place: Will the Funk Go?, N.Y. Times, July 21, 1996, § 13, at 6 .

452. NY COM, supra note 2, at 45. Similarly, the Fifth Avenue BID fought to eliminate an exemption from a ban on street peddling intended to help disabled veterans. See Martin, supra note 256, at B3. 
nizations. ${ }^{453}$ Yet, unlike these other organizations, the BID is funded by tax dollars which can give it an advantage in presenting its views to city decisionmakers and the media. ${ }^{454}$

Indeed, it could be argued that the relationship of the BID to the city is akin to that of the city to the state: The junior body is theoretically subordinate to its hierarchical superior but in practice enjoys sufficient policymaking autonomy that one person, one vote ought to apply. This would track Avery, in which the Supreme Court rejected the argument that due to the "extensive power" state governments wield over local units, the norm of democratic governance would be fully satisfied by the application of one person, one vote to the state legislature and need not be extended to localities.

The question is not free from doubt-and Judge Weinstein may have been correct in determining that the question should have been remanded for trial rather than determined on summary judgment $t^{455}$ but I am inclined to agree with Kessler that BIDs or, more precisely at present, New York City BIDs lack real autonomy.

BID authority is fundamentally limited. BIDs provide services, and they certainly enjoy some discretion with respect to the terms of service delivery, but they may not regulate private behavior or levy or collect taxes. They can recommend actions - and their proposals may be highly influential-but the implementation of their recommendations requires approval by an elected city government and the city government does not automatically endorse BID requests. 456 In Avery, the state had "delegate[d] lawmaking power to local government;" ${ }^{457}$ BIDs, however, lack that power.

New York City, in particular, has been taking a more adversarial posture toward its BIDs, with the Grand Central BID a particular target of municipal criticism. The City Council has conducted two critical examinations of BID activities, ${ }^{458}$ and the Comptroller has been auditing BID operations. ${ }^{459}$ Reacting to Grand Central's ambitious capital program,

453. See, e.g., Allon, supra note 253, at 6 (describing conflict between 14th Street/ Union Square BID and Union Square Community Coalition over plans for Union Square Park-community group prefers to expand park and reduce traffic, "but to the business group, fewer traffic lanes means less business"). See also Mark Francis Cohen, The Gritty and the Gentry Battle for a Waterfront's Soul, N.Y. Times, Feb. 4, 1996, § 13, at 10 (describing conflict between BID sponsor and Community Board over development of Red Hook district in Brooklyn).

454. In fiscal year 1997, New York City's BID assessments totalled $\$ 46.1$ million, or $\$ 8.3$ million more than the combined fiscal year budgets of the five borough presidents and 59 community boards. See Comptroller's Audit, supra note 395, at 3.

455. See Kessler v. Grand Cent. Dist. Mgmt. Ass'n, 158 F.3d 92, 133 (2d Cir. 1998).

456. See Manshel, supra note 24, at 105.

457. Avery v. Midland County, 390 U.S. 474, 480 (1968).

458. See Managing the Micropolis, supra note 96 , at $7-10$. The Council was particularly critical of the management of the Grand Central BID. See id. at 32-40.

459. See Frederick Gabriel, City Crackdown Leads to Audits for NY's 40 BIDs, Crain's N.Y. Bus., Aug. 18, 1997, at 1. 
the Giuliani administration prohibited BIDs from issuing bonded debt. ${ }^{460}$ In April 1998, the Commissioner of Business Services issued a new directive requiring BIDs to notify DBS of all their activities, new initiatives, budget changes and even contacts with other city agencies. ${ }^{461}$ In July 1998, the city dramatically underscored its willingness to oversee and control its BIDs when, citing the Grand Central Partnership's failure to comply with city rules and regulations, it terminated the Partnership's contract to manage the BID. ${ }^{462}$ The city has since been engaged in maneuvers to replace the Partnership with a more compliant managing board. ${ }^{463}$ In Mayor Giuliani's New York, at least, it appears that BIDs are subordinate to city government in practice as well as in theory. ${ }^{464}$

460. See Levy, supra note 170 , at 22.

461. See Philip Lentz, Giuliani Directive Puts the Handcuffs on BIDs: Gives Dep't. of Business Services Right to Approve Districts' Activities, Crain's N.Y. Bus., Apr. 6, 1998, at 4; Letter from the Commissioner of the Department of Business Services, City Tightens Control of BIDs, 4 City Law 46 (1998).

462. See Thomas J. Lueck, Business Improvement District at Grand Central is Dissolved, N.Y. Times, July 30, 1998, at B1. Despite the headline of the New York Times article, the city technically did not dissolve the Grand Central BID. Instead, it declined to renew the Grand Central Partnership's contract to manage the BID. The BID remains in place and if another entity can be found to manage the district, or if the Partnership could be reconstituted to the satisfaction of the city, then, simply by entering into a contract with the new or reconstituted management body, the city could enable the BID to resume operations.

The city's interest in reining in the Grand Central BID was signaled several months before the termination of the Grand Central Partnership's contract when the Giuliani administration indicated it would not approve a $3.9 \%$ budget increase, backed by an assessment increase, requested by the BID, and also would not approve the customary fiveyear extension of the Grand Central Partnership's contract for managing the BID, but might instead renew the contract for just one year. The city also sought to require the BID's president to step down as manager of two other midtown BIDs. See Lentz, supra note 171 , at 1 .

463. See Pristin, supra note 281, at B7. Mayor Giuliani's actions against the Partnership have even drawn criticism from editorial boards and columnists who normally support the Mayor. See, e.g., Heather MacDonald, BIDding Adieu, City J., Autumn 1998, at 6; This Was Not Rudy's Finest Hour, N.Y. Post, Dec. 6, 1998, at 7. As this article was going to press, The Grand Central Partnership, in an effort to make amends with the city and reestablish its contractual relationship, announced that it was hiring as its president Mayor Giuliani's Finance Commissioner to replace the controversial Daniel Biederman. See Terry Pristin, Finance Commissioner to Head Grand Central Business Group, N.Y. Times, Jan. 21, 1999, at B7. The once-obstreperous Grand Central BID may have been brought back into the fold of city government.

464. This analysis, of course, turns entirely on the scope of BID authority and municipal control under New York law and on the extent of city oversight and control in practice. If a state were to give a BID independent regulatory or taxing authority, or a city were to automatically rubber-stamp BID requests and fail to oversee the operations of a BID within its borders, the case for treating such a BID as autonomous and therefore subject to one person, one vote would be quite powerful. If, as some BID proponents have urged, BIDs are given greater authority to "manage" their districts, in the manner of a shopping mall owner managing a mall, then the BIDs would be more vulnerable to a one person, one vote challenge. The logic of the exemption of BIDs from one person, one vote is, thus, in some tension with the efforts of BID proponents who would like to make 
The second, more normative, challenge asks why the lack of "sovereign power" and the subordination to city control are relevant to the question of whether one person, one vote applies. In Avery, the Supreme Court sought to reconcile the values of democratic control with the freedom of states and localities to pursue "innovation, experiment and development among units of local government." 465 In extending one person, one vote from states to localities, the Court focused on the "policy and decisionmaking" autonomy of local governments-on the "delegation of power to local units" that operate outside the scope of direct state control. ${ }^{466}$ One person, one vote was held to apply to locally representative bodies that have the power to govern within their communities. But respect for the freedom of states and localities to innovate, to experiment with new mechanisms "suitable for local needs and efficient in solving local problems," 467 led the Court to refrain from imposing one person, one vote as a "uniform straitjacket" on all local governments.

One person, one vote is required where elected local governments have power to govern - to make policy, mandate payments, and coerce compliance-and can act outside the close control of a higher-level democratic government. For the rest, that is, for localities with more limited authority over the people within their jurisdiction, federalism-specifically, the "extraordinarily wide latitude that States have in creating various types of political subdivisions and conferring authority upon them" 468 - and the value of promoting experimentation in the forms of local governance counsel in favor of permitting states and local governments to create new local structures outside the scope of one person, one vote.

BIDs are a new local form that include a very old local tradition-a tradition in sharp tension with contemporary democratic values-of property owner voting. In the BID setting, property owner voting is tied to extra levels of district property owner taxation, as well as mechanisms for city oversight and ultimate city control. Although the property owners paying BID assessments may be able to diffuse those costs throughout the district, the assessment payers do bear the costs of the BID in the first instance. Their support is typically critical for the establishment of the BID and for its continuation. A state could reasonably conclude that BIDs are a useful means of providing urban services and that property owner voting control would facilitate creation of the BID. ${ }^{469}$ As long as a

the BID a downtown management entity. The more power BIDs get to directly affect the development of their districts, that is, the more the BID comes to resemble the "private" shopping mall manager, the more it has the powers of governance and would have to be subject to constitutional norms.

465. Avery v. Midland County, 390 U.S. 474, 485 (1968).

466. Id. at 481.

467. Id. at 485 .

468. Holt Civic Club v. City of Tuscaloosa, 439 U.S. 60, 71 (1978).

469. In his Kessler dissent, Judge Weinstein argued that property owner voting control is not necessary for the creation of BIDs since two states, Colorado and Florida, provide for 
BID's regulatory and fiscal powers are limited, and the city government has the capacity to oversee and control BID operations, property owner voting may be a constitutionally permissible component of local government innovation. 470

The determination that BID elections are not subject to one person, one vote does not mean that the BID is not a public body or that BIDs do not present questions of democratic accountability. BIDs are public bodies, often performing traditional public functions, but their authority and discretion are limited, and they are at least formally subject to oversight and control by elected municipal governments. Moreover, requiring one person, one vote would not assure democratic control of local government activities. More likely, states and cities would swiftly replace laws providing for elected boards with laws directing that governing boards be appointed by city hall. Indeed, in many jurisdictions BID boards currently are appointed, rather than elected. The one person, one vote re-

universal suffrage in BID elections. See Kessler v. Grand Cent. Dist. Mgmt. Ass'n, 158 F.3d 92, 132 (2d Cir. 1998). Judge Weinstein, however, misread the Colorado and Florida statutes he cited. In Colorado, a BID governing board will consist of persons elected by the electors of the district only if a petition signed by owners of least $50 \%$ of the assessed value property in the district so provides. See Colo. Rev. Stat. § 31-25-1209(1)(d) (Supp. 1996). Otherwise, the board is not elected but appointed by the governing body of the municipality. Colorado's largest BID, the Downtown Denver Business Improvement District, is governed by such an appointed body, which is composed primarily of private sector representatives. As one study found, “ $[w]$ hile the BID's legal framework resembles that of a public agency, it thus far functions like a non-profit organization controlled by business and property owners." Houstoun, BIDS, supra note 1, at 152. The Florida statutes Judge Weinstein cited dealt not with BIDs but with "community development districts." These are districts authorized to finance and operate capital infrastructure for developing communities. See Fla. Stat. Ann. $§ \S 190.001-.049$ (West 1987 \& Supp. 1999). They are frequently created and operate in advance of the incorporation of municipalities in rapidly growing areas on the urban fringe as part of the development process, and may ultimately become incorporated. See Fla. Stat. Ann. $\S 190.047$ (West 1987). In their critical initial years of operation, they are governed by boards of supervisors elected by landowners on a one acre, one vote basis. See Fla. Stat. Ann. § 190.006(2) (b) (West Supp. 1999). The Florida Supreme Court rejected a one person, one vote challenge to such acreage-based elections, finding that the districts did not exercise "general governmental functions." State v. Frontier Acres Community Dev. Dist. Pasco Co., 472 So. 2d 455, 457 (Fla. 1985).

470. This analysis is strongly shaped by the legal and factual context presented in Kessler. If a BID was authorized to exercise independent regulatory or taxing authority, the case for treating it as an autonomous government subject to the one person, one vote requirement, would be significantly stronger. Nor does this analysis dispose of all legal questions presented by the limitation or denial of the right to vote to nonowner or nonbusiness residents in BID elections. For example, an election may fall within the scope of the right to vote protected by the Voting Rights Act even if it is not subject to the Equal Protection Clause's one person, one vote requirement. See Chisom v. Roemer, 501 U.S. $380,390-91$ (1991). The question of whether a BID formation election is subject to the Voting Rights Act has been litigated but without an opinion on the merits. See ParkerWeaver v. Fordice, 119 S.Ct. 791 (1999) (affirming district court dismissal, for lack of standing, of suit challenging Mississippi's failure to seek Justice Department preclearance of BID enabling legislation). 
quirement does not apply to appointed bodies, ${ }^{471}$ and there is little to prevent city governments from packing appointed BID boards with district landowners and merchants. ${ }^{472}$ There is no reason to think such boards will be any more accountable to district residents than boards elected by district business interests. ${ }^{473}$

Conversely, some democratic accountability may be obtained even without democratic BID elections if the city is committed to effective control of its BIDs. Under those circumstances, though, democratic control will occur at the city level rather than at the district level. Democratic accountability is ultimately about the relationship between a city and a BID. That relationship is considered more fully in Part IV.

\section{B. State Tax Limitations and BID Assessments}

Most of the litigation against BIDs comes not from propertyless residents, but from the property owners or firms said to be benefited by BIDs. These plaintiffs are concerned not about governance or services, but about the higher level of taxation BIDs entail.

The legal basis for these challenges is provided by various state constitutional provisions restricting local taxation. Many state constitutions require "uniformity of taxation"; that is, the assessment and taxation of similar properties at the same rate. A BID assessment can create a uniformity question when a property located within a BID is required to pay a charge while a property of comparable value outside the district, but within the same city, is not. Many state constitutions also impose substantive and/or procedural limits on local taxation. States may cap the level of local property taxation or the amount of local property revenues as a percentage of local property values. States may require a local vote to increase property taxes above a certain level. A BID assessment could subject a property owner to more taxation, or produce more revenue, than is permitted under a tax limit. If a BID charge is imposed without a referendum, that could violate a state's requirement of voter approval for new taxes.

BIDs have sought to repel these attacks by asserting that BID charges are special assessments and, therefore, exempt from many of the state

471. See Sailors v. Board of Educ., 387 U.S. 105, 110-11 (1967).

472. See Quinn v. Millsap, 491 U.S. 95, 106-09 (1989) (Missouri law imposing property ownership qualification for appointment to board created to propose municipal government restructuring failed rational basis test). Though Quinn might invalidate a law limiting BID boards to landowners or merchants, a rule giving assessment payers a dominant, albeit not an exclusive, voice might pass constitutional muster. If not, a locality could simply make it a practice, without a legal requirement, of giving majority representation on BID boards to assessment payers.

473. Publicly appointed boards are as likely to be dominated by private sector interests as boards elected by businesses or property owners. When a city government appoints a board, typically "it appoints men and women recommended by the board's original organizers." These boards "function with as much of a private sector perspective as they would if they were selected by their peers." Houstoun, ULI, supra note 3, at 11 . 
constitutional norms applicable to general taxation. As previously noted, although a special assessment is a compulsory charge, state courts tend to treat an assessment as more like a fee for a service than a tax that goes into the coffers of government. Special assessments are limited to recouping the costs the assessing locality incurs in providing the benefit, and by the requirement that the benefit a payer receives must be as large as the assessment he or she pays. These rules, which are part of the very definition of a special assessment, presumably protect against government exploitation of taxpayers, and thus relieve localities using assessments of the need to comply with the uniformity rule, a tax ceiling, or a referendum requirement.

As noted in Part II, BID assessments may differ from traditional special assessments. Whereas the latter are generally used to fund physical infrastructure aimed at improving access to, or the usefulness of, abutting or adjacent parcels of land, BID assessments often fund services such as policing, public events, strategic planning, marketing and promotions that serve a district as a whole but lack close connections to individual parcels. These differences raise the question of whether BID activities provide the kind of benefits needed to justify an assessment.

Moreover, the nature of BID activities makes it more difficult to determine the amount of the benefit to individual payers, or, indeed, whether all payers are benefited in proportion to their assessments. Businesses that do not rely on street traffic or walk-in trade may see little advantage in activities that promote clean, safe and active streets. BID programs to plan business strategy or develop the district's image may do little for firms whose businesses do not fit the image. Some BIDs have developed complex financing formulas, varying assessments according to location within the district, size of the parcel, or use of the property, in an effort to calibrate the payment to the benefit. Many BIDs, however, use relatively simple criteria, such as square footage, front footage, assessed valuation or property tax payments as the basis for the imposition of an assessment. ${ }^{474}$ These formulas do little to assure that each parcel or firm receives a benefit equal to its assessment. Thus, even if assessments may be used to finance area-wide business-oriented services in theory, they may be vulnerable to claims by individual payers who assert that assessment-financed activities do not benefit them in practice.

State courts have, so far, agreed that BID charges are assessments, and, thus, can neither run afoul of uniformity clauses, ${ }^{475}$ nor be invali-

474. See, e.g., Houstoun, BIDs, supra note 1 , at 30-35.

475. See S.O.L. Club, Inc. v. City of Williamsport, 443 A.2d 410, 411-12 (Pa. Commw. Ct. 1982); City of Seattle v. Rogers Clothing for Men, Inc., 787 P.2d 39, 49 (Wash. 1990). See also McGowan v. Capital Ctr., Inc., 19 F. Supp. 2d 642, 649 (S.D. Miss. 1998) (BID assessment not subject to Mississippi constitution's uniformity requirement and not violative of federal equal protection clause). But cf. Jensen v. City \& County of Denver, 806 P.2d 381, 384-85 (Colo. 1991) (BID assessment subject to, and consistent with, Colorado Constitution's Uniformity Clause). 
dated for failing to abide by constitutional limits on tax increases. ${ }^{476}$ In so doing, they have accorded relatively little significance to the differences between BID assessments and more traditional special assessments. ${ }^{477}$ In the leading case of City of Seattle $v$. Rogers Clothing for Men, Inc. ${ }^{478}$ the Washington Supreme Court dismissed the argument that assessments could be used to finance only permanent capital improvements and not services. The city had imposed an assessment to finance two programs of the Downtown Seattle Retail Core Business Improvement Area-a "marketing program" aimed at decorating and beautifying public places, maintaining signs, advertising and improving public relations, and a "maintenance program" providing street cleaning, graffiti removal and security services. The court held that the city was free to authorize the use of the assessment to fund services, including those that provide primarily "aesthetic improvements," ${ }^{479}$ so long as the assessment-funded activity actually provided a benefit to property. ${ }^{480}$

Turning to whether the assessment-funded services actually benefited the plaintiff store owners, the court followed state precedents that presume that assessment-funded activity provides a benefit at least as great as the charge for it, and that place the burden on the plaintiffs to prove that the assessment "substantially exceeded their benefit." 481 As the court explained, "[i]t is presumed that a local improvement benefits property unless the challenging party produces competent evidence to the contrary. The burden of proof shifts . . . only after the challenging

476. See Evans v. City of San Jose, 4 Cal. Rptr. 2d 601, 606-08 (Cal. Ct. App. 1992). See also Quapaw Cent. Bus. Improvement Dist. v. Bond-Kinman, Inc., 870 S.W.2d 390, 392 (Ark. 1994) (Arkansas constitution's limitation on maximum rate of general property taxation does not apply to improvement districts).

477. Courts have distinguished BID charges from taxes in other settings. In Federal Reserve Bank v. Metrocentre Improvement Dist. \#1, 657 F.2d 183 (8th Cir. 1981), the court considered whether the Federal Reserve Bank was subject to a BID assessment. Federal agencies are normally immune from state and local taxation but, under federal law, may be required to pay "taxes upon real estate." Id. at 186-87 (citing 12 U.S.C. § 531). The court concluded that the waiver of immunity from real estate taxes did not apply to special assessments, as opposed to taxes, and that a BID assessment was more like an assessment than a property tax. See id.

In Easley v. City of Lincoln, 330 N.W.2d 130 (Neb. 1983), the court considered whether publicly owned land within the proposed district ought to be counted in the assessable property base for the purpose of determining whether the fraction of district property owned by landowners protesting formation of the BID was sufficient to block the BID. The court observed: "It is axiomatic that, ordinarily, public property is exempt from general purpose taxation." But tax-exempt property may be subject to a special assessment "levied by reason of special benefits conferred upon the property." Id. at 131. The publicly owned property could be subject to a BID assessment and thus had to be counted in determining the sufficiency of the protests. See id. at 135.

478. 787 P.2d 39 (Wash. 1990).

479. Id. at 46. See also S.O.L. Club, Inc. v. City of Williamsport, 443 A.2d 410 (Pa. Commw. Ct. 1982) (BID assessment used to finance purely aesthetic improvements is not subject to a uniformity clause challenge).

480. See Rogers Clothing for Men, Inc., 787 P.2d at 45-47.

481. Id. at 47. 
party presents expert appraisal evidence showing that the property would not be benefitted by the improvement." 482 The fact that the BID assessment funded area-wide services did not change the presumption and the allocation of the burden of proof developed in earlier assessment cases. Moreover, the Seattle BID had adopted a very complex assessment structure that took into account type of use, square footage, and location within the business improvement area in determining the assessment imposed on particular property owners. ${ }^{483}$ Although plaintiffs argued that the assessment formula was designed to limit the assessments imposed on large department stores, thereby placing a disproportionate burden on smaller retailers, ${ }^{484}$ the court found that the challengers had not sustained "their heavy burden of overcoming the presumption of the ordinance's constitutionality." 485

Similarly, in Evans v. City of San Jose, ${ }^{486}$ the California Court of Appeal held that the requirements of Proposition 13, California's famous voter-initiated tax limitation, did not apply to BID charges. San Jose authorized a BID proposed by the San Jose Downtown Association, and imposed an assessment, consisting of charges to hotels and apartment buildings, for the BID's downtown promotion activities. The plaintiff, who owned an apartment house within the district and had filed an unsuccessful written protest against the BID's formation, asserted that the BID charge was unconstitutional because it had been levied without the referendum that Proposition 13 requires for special taxes. California courts had previously determined that special assessments are not "special taxes" within the meaning of Proposition 13, but the plaintiff contended that the San Jose assessment was neither a charge on real property nor used to finance public improvements specifically benefiting assessed real prop-

482. Id. at 48 .

483. See id. at 42-43. The ordinance created five different classes of business spacedeveloped ground floor business space, individual commercial retail sales space at the basement level or on the second or third floors, major multilevel retail stores, parking garages and surface parking lots, and other uses. Each classification was assessed separately for the BID's marketing program and for its common area maintenance program.

484. The ordinance creating the BID and authorizing the assessment assessed large multilevel department stores for their ground floor footage and for just one other floor, while other, smaller retailers were assessed on all their floors. In addition, there was a ceiling of $\$ 28,000$ on the amount of assessment to be imposed on any one business regardless of square footage. See id. at 43 . Two of the three department stores in the business improvement area had their assessments capped by the ordinance. See id. at 51 n.48.

485. Id. at 51. See also Mound Hardware v. City of Spokane, No. 16487-0-III, 1997 Wash. App. LEXIS 1940, at *6-7 (Wash. Ct. App. Nov. 25, 1997) (“[I]t is presumed that an improvement is a benefit, an assessment is no greater than the benefit, an assessment is equal or ratable to an assessment upon other property similarly situated, the assessment is fair and evidence of appraisal values and benefits is necessary to rebut these presumptions.").

486. 4 Cal. Rptr. 2d 601 (Cal. Ct. App. 1992). 
erty, and therefore it was not a special assessment at all and so not exempt from Proposition 13.

Evans agreed with the plaintiff that "[ $\mathrm{t}] \mathrm{he}$ assessment on businesses for downtown promotion is not a true special assessment." 487 Nevertheless, the court found that the BID charge, although not based on property and not used to provide a benefit with a close nexus to property, was more like a special assessment than a special tax. Like a special assessment, the San Jose assessment was intended to benefit a "discrete group," rather than the city as a whole; and, as with a special assessment, the group benefited was the group subject to the assessment. ${ }^{488}$ As in Rogers Clothing for Men, the court deferred to the determinations of the state legislature and the city council "that downtown promotion inures to the benefit of businesses and landlords within the BID . ..."489 The fee was, thus, exempt from Proposition 13's referendum requirement.

In the absence of clear legislative language subjecting BID charges to the restrictions applicable to general taxes, BID impositions are usually treated as assessments rather than the taxes they resemble. ${ }^{490}$ Rogers Clothing for Men and Evans are important since they involved BIDs whose programs and charges differed most sharply from the traditional uses and structure of the special assessments. These BIDs focused on marketing and promotion activities, rather than physical improvements, and their charges were imposed on business activities rather than property.

The state court treatment of BID charges as assessments is not unreasonable. Although the assessment was traditionally used to finance capital investment, in theory an assessment is distinguishable from a tax simply because it provides a special benefit to the payer. Since services can provide a benefit, assessments need not be limited to physical improvements. Indeed, in the past, assessments had on occasion been used for services, particularly the maintenance of improvements. So, too, even before the advent of BIDs, local governments had attenuated the connection between an assessment and the benefits to specific parcels of land. In recent years, cities and counties have used the special assessment to finance facilities such as parks, arterial roads, and off-street parking that provide benefits less tightly tied to particular parcels. 491 These uses did not challenge the theory of the assessment since property may be bene-

487. Id. at 607 .

488. See id.

489. Id. at 608 .

490. Some states have assimilated BID assessments to taxes for some purposes. In New York, assessments count toward the state constitutional cap on local property taxation-with no apparent harm to the proliferation of BIDs in that state. See N.Y. Gen. Mun. Law $\S 980-k$ (b) (McKinney Supp. 1999). See also Jensen v. City \& County of Denver, 806 P.2d 381, 384-85 (Colo. 1991) (finding BID assessment subject to, and consistent with, the Colorado Constitution's Uniformity Clause).

491. See, e.g., Heavens v. King County Rural Library Dist., 404 P.2d 453 (Wash. 1965) (striking down law assessing property to pay for construction of libraries). 
fited by an improvement in the vicinity of the parcel even if the improvement does not abut or physically connect to the assessed property.

Nevertheless, by using assessments to pay for activities that are both area-wide in scope and operational instead of capital in nature, BIDs have pushed out the envelope of assessment uses. In so doing, they have greatly benefited from judicial use of rules-such as the presumption of benefit and the placement of the burden of proof on challengers ${ }^{492}$ that first crystallized when assessments were used primarily to fund improvements with a tighter nexus to particular parcels. Moreover, the precedents set in cases involving BIDs may give local governments even greater discretion to use assessments and BID-like entities to finance areawide services free of the restrictions of state constitutional restrictions on local taxation.

Strikingly, in validating the BID assessments, these courts focused less on assuring that individual payers actually benefit to the extent of the charges imposed on them and more on determining that the benefits flowing from the charges were confined largely to the district subject to assessment and did not spread to the rest of the city. As Evans emphasized, the test of the legality of the assessment was whether a "discrete group is specially benefited by the expenditure of these funds." 493 Rogers Clothing for Men noted that the assessments paid for "activities that took place within, and advertising that benefited, the Business Improvement Area," 494 and concluded that the "assessments were local in nature rather than general." 495 In other words, for these courts, the critical distinction was not between benefit to "private" property versus benefits for "public" purposes, but benefit to the district as opposed to benefit to the city as a whole.

The emerging legal test of a BID assessment appears to be distinctive benefit to a district, rather than benefit to each payer. Courts have allowed states and local governments to use BIDs to move the special assessment further along the continuum from its original inspiration as a compulsory fee for an improvement that provides a fairly concrete benefit to the payer to something more like a tax that funds general governmental services for a neighborhood. In effect, these cases say that BID assessments can be used to fund public benefits so long as the benefit is confined to the district in which the assessments are collected. Ironically, the

492. See Mound Hardware v. City of Spokane, No. 16487-0-III, 1997 Wash. App. LEXIS 1940, at *9 (Wash. Ct. App. Nov. 25, 1997) ("[T] he services provided by the PBIA [Parking and Business Improvement Area] are presumed to benefit all property owners and businesses within the area, and thus to be a valid assessment."). As one BID executive recently observed, a BID's calculation of the benefits used to determine assessments "doesn't have to be accurate. It just has to be supportable [in court]." Donald Shea, Comments at Conference on Business Improvement Districts: Mastering the Basics and Exploring Innovation (May 3, 1998) (on file with the Columbia Law Review).

493. 4 Cal. Rptr. $2 d$ at 607.

494. City of Seattle v. Rogers Clothing for Men, Inc., 787 P.2d 39, 47 (Wash. 1990). 495. Id. 
very public service inequality that so troubles many BID critics is essential for the legal exemption of BIDs from the rules limiting local taxes.

In California, BID assessments are now subject to Proposition 218, a voter-initiated measure that amended the California Constitution in 1996 to require any local "agency" proposing an assessment to notify each landowner by mail of the amount of assessment to be levied against that parcel and to include in the mail a ballot enabling the owner to register his or her support or opposition to the assessment. ${ }^{496}$ If a majority of those returning ballots, weighted according to the financial obligation of the affected property, oppose the assessment, it may not be imposed.497 Proposition 218, thus, authorizes property owners to protest BID assessments as well as to protest the formation of the BID. It enables a majority of those voting to block an assessment, rather than requiring opposition from a majority of those eligible to vote. ${ }^{498}$ Given that California requires signatures representing a majority of district assessments to initiate BID formation, 499 it is unclear whether the Proposition 218 vote will block many assessments. ${ }^{500}$ Still, it places a new burden on BIDs to obtain affirmative support from property owners. It also takes the important step of assimilating assessments to taxes by applying the California constitutional principle of voter approval of new or increased taxes to assessments - with the twist that voter approval of assessments means approval by property owners. ${ }^{501}$

Proposition 218 also requires an assessing agency to calculate the "proportionate special benefit derived by each identified parcel" subject to assessment, with proportionate special benefit "determined in relationship to ... the capital cost of a public improvement, the maintenance and operation expenses of a public improvement, or the cost of the property related service being provided." 502 This could constrain the ability of BIDs to use assessments for activities-such as "promotion of public

496. See Cal. Const. art. XIII D, § 4(c-d).

497. See Cal. Const. art. XIII D, § 4(e).

498. Requiring a majority from those eligible to vote in order to block a BID assessment would mean that nonvoter property owners are counted as supporters of the assessment. Under Proposition 218, nonvoters are simply not counted. See Cal. Const. art. XIII D, $\S 4(\mathrm{c})$ (requires agency to tabulate all ballots it receives and then determine if there is a "majority protest").

499. See Cal. Sts. \& High. Code $\S 36,621$ (a) (West Supp. 1999).

500. See, e.g., Patrick McGreevy, City OKs Tarzana's Improvement District, L.A. Daily News, Aug. 6, 1998, at N3.

501. See Cal. Const. art. XIII D, $\S 4(\mathrm{~g})$. Proposition 218 provides that if the propertyowner-only mail-in ballot is held unconstitutional, then assessments may be authorized only if they receive approval from both two-thirds of the general electorate and through the property-owner mail-in ballot process. See id. If, however, voting on assessments is encompassed within the constitutional protection of the right to vote, so that the limitation of the franchise to property owners is unconstitutional, then requiring the approval of both non-owner residents and property owners is unlikely to be constitutional either. See Hill v. Stone, 421 U.S. 289 (1975).

502. Cal. Const. art. XIII D, $\S 4(a)$. 
events [and] tourism," "marketing and economic development," and "retail retention and recruitment"503 - that do not provide direct benefits to property, or that provide benefits that are difficult to apportion to individual properties according to traditional assessment formulas like front footage or assessed valuation. Or it could require California BIDs to make more of an effort to come up with defensible projections of the likely benefit of a particular program for each assessed parcel. ${ }^{504}$ On the other hand, given the liberal reading California courts have given to the concepts of special benefit and improvement, ${ }^{505}$ this provision of Proposition 218 could be nullified by a liberal interpretation of "property related service" 506 and by judicial deference to BID calculations of the benefit that each parcel will reap from a district's tourism promotion or business recruitment program.

It is not clear whether Proposition 218 applies to BIDs funded by special assessments against businesses, such as those validated in Rogers Clothing for Men and Evans. Proposition 218 defines an assessment as a "levy or charge upon real property," 507 so taxes against businesses appear not to be affected by the Proposition's rules governing assessments. Antitax groups, like the Howard Jarvis Taxpayers Association and the San Diego Taxpayers Association, however, contend that assessments against businesses are "special taxes" and, thus, under a different provision of Proposition 218, must be approved by two-thirds of the electorate in a referendum. ${ }^{508}$ Evans had exempted BID charges against businesses from Proposition 13's requirement of voter approval for "special taxes" because the proceeds were reserved for the "discrete group" paying the charges rather than made available to the city as a whole, and, thus, were more like an assessment against property. But that was before the ratification of Proposition 218's new limitations on assessments against property. Proposition 218 defines "special tax" as "any tax imposed for specific purposes, including a tax imposed for specific purposes, which is

503. Cal. Sts. \& High. Code $\S 36,613$ (a, c-d) (West 1999).

504. According to Marianne Giblin, executive director of the Downtown Los Angeles Property Owners Association, the entity that manages the Los Angeles Fashion District BID, Proposition 218 "puts a more stringent requirement" on the nexus between cost and benefit and is likely to "put an end to the sweetheart deals" in which some BID parcels were underassessed relative to the benefits they received. Marianne Giblin, Comments at Conference on Business Improvement Districts: Mastering the Basics and Exploring Innovation (May 3, 1998) (on file with the Columbia Law Review). Giblin noted that Proposition 218 can have one benefit for BIDs since it requires public properties, which had hitherto been exempt from assessment, to pay into assessment districts, unless they are shown to receive no special benefit. See Cal. Const. art. XIII D, § 4(a).

505. See, e.g., Knox v. City of Orland, 841 P.2d 144, 149-52 (Cal. 1992) (upholding assessments for maintenance of public parks).

506. Cal. Const. art. XIII D, §4(a).

507. Cal. Const. art. XIII D, § 2(b).

508. See Mike Allen, Business Improvement Districts Threatened?, 18 San Diego Bus. J. 1, June 9, 1997, at 1; Terry Rodgers, 1st Court Test of Prop. 218 May be Here, San Diego Union-Trib., June 11, 1997, Ed. B-1, at 7-8. 
placed into a general fund." ${ }^{509}$ It is not clear whether "placed into a general fund" includes assessments that are collected by a city but earmarked for a business improvement district. The issue may receive judicial clarification in a suit brought by a taxpayers' group against the City of San Diego, which has sixteen BIDs financed by assessments against businesses. ${ }^{510}$

These cases, and the uncertainties created in California by Proposition 218, shed new light on the theme of public versus private that runs through the story of BIDs. In deferring to the determinations of state and local legislatures that BID programs benefit businesses or property owners in the districts-over the protests of owners who claim they have not been benefited-state courts have implicitly underscored the public nature of BID assessments. Both Evans and Rogers Clothing for Men noted the role of local governments in creating the BIDs and authorizing the assessments. The BIDs were seen as implementing the municipal interest in delivering special services to the business district, not as devices for promoting the autonomy of the business district. The practice of judicial deference to legislative bodies in matters concerning assessments better explains the validation of BID charges than does any notion of the BID as a quasi-private body. So, too, the adoption of Proposition 218 suggests that for at least some California voters, the problem with BIDs and similar entities is that their charges finance programs that are potentially too "public," that is, programs that provide benefits that are spread broadly across districts rather than tied tightly to specific parcels or assessment payers.

By the same token, the state taxpayer cases suggest that the "publicprivate" tension immanent in the proliferation of BIDs is not just a matter of private property versus public government but is also a question of the role of discrete taxing and spending districts within cities. The BIDs survived these challenges because their assessments, although collected pursuant to municipal authorization, were devoted to the benefit of the districts in which they were collected and were not used to fund programs for the "community at large." ${ }^{11}$ In effect, the notion of private benefit to individual assessment payers was transmuted into the private benefit of the assessment districts. If California's business-financed BIDs escape the application of Proposition 218, it is likely to be for the same reason-that the BIDs' funds are devoted to the districts rather than the city as a whole.

509. Cal. Const. art. XIII C, §1(d).

510. See Ray Huard, Taxpayer Group Sues San Diego Over Prop. 218, San Diego Union-Trib., July 4, 1997, Ed. B-1, at 1. In an initial ruling, the Superior Court determined that Proposition 218 did not apply to business fee-funded BIDs. See Mike Allen, Business Improvement District Edict Favors City, 19 San Diego Bus. J., Apr. 20, 1998, at 1.

511. City of Seattle v. Rogers Clothing for Men, Inc., 787 P.2d 39, 46 (Wash. 1990). 


\section{BIDs and Public Values in Urban Governance}

Critics of BIDs assert that the districts undermine public values central to urban governance. BIDs, they argue, violate longstanding public norms of democratic accountability and equitable provision of public services. As previously noted, the issue of accountability underlies and drives the one person, one vote challenge, but one person, one vote and democratic accountability are not interchangeable. However the constitutional issue is resolved, the accountability question will remain. Cities can take steps to oversee BIDs more effectively and to protect the public interests implicated by BID operations. The issue of accountability is ultimately a matter of the willingness of city governments to engage in more vigorous monitoring and control.

The public service inequality question is the mirror image of the legal challenges to BID assessments: BID property owners and businesses are required to pay additional taxes, but they receive additional services-services based not on some municipal determination of need but on the BID's willingness and ability to pay. BIDs, thus, by definition, create intralocal inequalities in public services. Although interlocal differences in tax base and tax rates have long produced interlocal differences in the quantity and quality of public services, BIDs make willingness and ability to pay a formal factor in the provision of services within a city. So far, however, the degree of inequality is relatively modest. BIDs often provide benefits to people outside the districts and to their cities as a whole. The issue remains troubling and requires a careful consideration of the tradeoff between the norm of intralocal equality and the benefits of providing extra services to the business districts that are often critical to the well-being of a city.

\section{A. BIDs and Democratic Accountability}

BIDs present three different problems of accountability: accountability to district residents, to city governments and to the BIDs' business or property owner constituents. First, BIDs have an impact on all district residents. BID services-the provision of cleaner, safer streets and the repair of dilapidated parks - will often be highly beneficial to district residents. Other BID activities may cause resentment. BID marketing strategies and development policies can conflict with the preferences of residents and current commercial tenants, ${ }^{512}$ and BID order maintenance activities can be controversial. Moreover, although only landowners are subject to assessment in districts funded by property assessments, these

512. See, e.g., Zukin, supra note 23, at 35 (community board opposition to BID's program of capital improvements); Allon, supra note 254, at 6 (conflict between 14th Street/Union Square BID and Union Square Community Coalition over whether to expand park if that would reduce access to local businesses); Joe Sexton, Standoff Over Red Hook Renewal: Businesses Fear a Plan to Remake a Neighborhood, N.Y. Times, Jan. 5, 1996, at B1 (conflict between community board and BID in Red Hook section of Brooklyn). 
owners are often able to pass the assessments along to tenants. Despite these broader impacts on residents and commercial tenants, BID boards are generally dominated by representatives of assessment payers and accordingly see themselves as instruments for the advancement of interests of assessment payers. District residents and commercial tenants may have little opportunity within the structure of the BID to see that their concerns are taken into account.

Second, BID activities can affect other city neighborhoods. BID security and order maintenance programs may displace crime and social problems onto adjacent communities. ${ }^{513}$ Similarly, BID programs, such as the financing of police substations, can attract the investment of additional city services into the district. BID marketing and development programs may draw customers and investment away from other areas of the city. ${ }^{514}$ BID efforts to promote a sense of district distinctiveness may detract from the unity of the city as a whole.

Most state laws provide ample opportunities for municipal oversight and control of BIDs. The municipality has broad discretion over whether to create the BID in the first place, and the municipality can shape the BID's boundaries, finances and service plan. Changes in boundaries or assessment structure require municipal approval, and representatives of city government may sit on the BID's board. In many states, the municipality has power to dissolve the BID at any time. Where the BID is approved for a limited term, the municipality may decline to renew the district at the end of its term.

Yet, it is unclear how vigorously municipal governments actually oversee their BIDs. ${ }^{515}$ Municipalities generally devote more attention to the creation of BIDs than to checking on BIDs once they are operational, and the administrative resources for overseeing BIDs are often quite limited. Cities look to BIDs to provide the public services that some landowners or commercial interests insist they need in order to remain in the city. BIDs provide these services without burdening the local public fisc. Thus, city governments are, to an extent, dependent on BIDs, and many have promoted the formation of BIDs. At a time of intense interlocal competition for investment, it may be difficult for city governments to be

513. See, e.g., Kennedy, supra note 7, at 319; Deutsch, supra note 105, at 9 (quoting Bryant Park BID director Daniel Biederman, "We felt guilty when we evicted the bad guys from Bryant Park, since we know we didn't eradicate them."). But see Joseph Hanania, Next LA: Making BIDs on the Future, L.A. Times, Jan. 7, 1997, at B2 (quoting consultant's remarks that successful BIDs have beneficial spillovers and stimulate development in adjacent areas).

514. See, e.g., Devin Leonard, Dazzled by Times Square, Nasdaq Boss Frank Zarb May Snub Wall Street, N.Y. Observer, Jan. 11, 1999, at 1 (describing efforts of the Downtown-lower Manhattan BID to lure the National Association of Securities Dealers to lower Manhattan, rather than the Times Square area).

515. See, e.g., IDA, supra note 10, at 28; Houstoun, Betting, supra note 2, at 18 (" $[E]$ ven where city councils approve board members, meaningful accountability, checks and balances, and public scrutiny usually are absent."). 
both supervisors and critics as well as promoters and cheerleaders of BIDs.

Third, questions have arisen concerning the accountability of BIDs to their own assessment-paying constituents. Indeed, the two New York City Council studies of BIDs gave more attention to the relationship between BIDs and district property owners than to any other aspect of BID accountability. ${ }^{516}$ This "internal" BID accountability problem is the product of several factors. District property or business interests are not monolithic. There can be conflicts between office building owners and retail property owners, between commercial property owners and residential property owners or between small owners and large owners over assessment formulas, service priorities and development strategies. ${ }^{517}$ The combination of small district size and the power of coercive taxation raises the classic Madisonian possibility of tyranny by a majority factionwith the added fillip that in those districts where a small number of owners pay a large proportion of the assessments and voting is based on assessed valuation, the dominating majority may actually represent a small fraction of the total parcels in the district. Conflicts between assessment payers and BID officers and directors may compound the potential for conflicts among assessment payers. Many BIDs are sponsored and managed by pre-existing public-private partnerships, chambers of commerce, merchants' associations, and local development corporations which benefit financially from the guaranteed income provided by BID assessments. BIDs may lease space or purchase services from, or make grants or loans to, these organizations or other community-based entities whose officers or directors serve on BID boards. ${ }^{518}$ The New York City Council Report found that " $[t]$ he common affiliations between BIDs and these other organizations raise concerns regarding potential conflicts of interest, the improper utilization of BID funds and, in the case of BID managers, the actual time spent working for the BID."519 The Council Report suggested that in some instances BIDs may be "cash cows" for these affiliated organizations. ${ }^{520}$

Smaller property owners may be particularly vulnerable to exploitation by larger payers and managers. Small owners may have formal voting rights on BID boards, but if votes are allocated according to assessments, and property values are concentrated in relatively few hands, they may easily be outvoted by a small number of large owners. With compulsory assessments, exit from the BID is far more difficult than quitting a chamber of commerce or downtown association. It is difficult for individual small owners to monitor BID activities; their assessments are small-

516. See Cities Within Cities, supra note 181, at iv; Managing the Micropolis, supra note 96 , at $8-10$.

517. See, e.g., Managing the Micropolis, supra note 96, at 7-10.

518. See Cities Within Cities, supra note 181, at 31-42.

519. Id. at $31-32$.

520. See id. at 32 . 
just a tiny fraction of their taxes-relative to the time and effort it would take to effectively investigate BID operations. In theory, the requirement that a landowner paying a special assessment must receive a benefit at least as great as the payment ought to provide some protection from exploitation. But, as Part III indicates, courts tend to defer to legislative determinations of benefit. Moreover, it may not be financially worthwhile for small payers to litigate over the uses of their assessments. Again, in theory, dissatisfied owners can seek to dissolve a BID, or to veto its renewal, but small owners are difficult to organize, particularly when the burden falls on them to gather the votes needed to cross the statutory threshold of legally significant opposition.

BID accountability is, thus, a real cause for concern. The problems, however, are not insurmountable, and may be addressed by relatively modest legal and administrative reforms. The most important actionone which would serve the interests of residents, assessment payers, and the city as a whole-would be the adoption of a sunset requirement. BIDs should be created for fixed terms and forced out of business at the end of that term unless reestablished by the city pursuant to a process similar to that required for initial creation of the BID. An appropriate term length would be five years-long enough for the BID to get underway without its organizers having to immediately divert their efforts to reauthorization and long enough for BID programs to show some benefits, but not so long as to insulate the BID from its constituents. ${ }^{521} \mathrm{~A}$ sunset and reauthorization requirement would give both assessment payers and residents the opportunity to register their views concerning the impact of the BID. It would provide the occasion to force a city to reconsider the BID, and to reassess its costs and benefits for district businesses and property owners, for district residents, and for the city as a whole. To make the reauthorization process meaningful, BIDs should be required to demonstrate adequate notification to all district interests-residents and commercial tenants, as well as assessment payers-of the impending reauthorization, and the city should not act until after such notice and a public hearing. ${ }^{522}$

Further, cities need to devote greater resources to oversight and control in the periods between authorization votes. BIDs are creatures of city government, established to provide city services, and to promote the city's interest in the well-being of its business areas. Cities have plenary authority over BIDs. Cities need to take more seriously their obligations to mon-

521. As noted in Part I, many states already limit BIDs to a term, limit the period of a BID's assessment or, as in New York, limit the duration of the contract with the district management association. A sunset requirement, thus, would not be a drastic departure from existing law, although not all states that impose terms require a full reauthorization process, and many states do not limit the duration of BIDs at all.

522. The New York City Council has found that procedures for notifying property owners of the pendency of a BID proposal are often flawed and that property owners may fail to receive proper notice. See Managing the Micropolis, supra note 96, at 20-30. 
itor their creatures and agents, and to take appropriate administrative action to make BIDs more responsive to democratic controls. Cities should ensure that there is both a city council committee and an executive branch agency responsible for overseeing BID activities, with staffing commensurate with the number and size of the city's BIDs. City governments should require BIDs to submit annual reports on BID programs and finances both to the city and to district property owners. Similarly, cities should adopt—or require their BIDs to adopt-rules limiting the conflicts of interest posed by the non-BID affiliations of BID managers and directors. ${ }^{523}$

The New York City experience provides some basis for the hope that cities can rise to the challenge of overseeing their BIDs. The city government has long been highly supportive of its BID program, and has actively promoted the formation of new BIDs. More recently, as questions of accountability have arisen, the city has begun to give greater attention to the finances and management of existing BIDs. Mayor Giuliani barred BIDs from incurring any new debt. ${ }^{524}$ The City Council issued two critical reports, along with recommendations for new legislation to improve city oversight and BID accountability. The City Comptroller issued a critical audit of the Grand Central BID and announced he would audit all of the city's BIDs. ${ }^{525}$ In April 1998, Mayor Giuliani directed BIDs to discuss "all activities and initiatives" with the city's Department of Business Services "at the first opportunity and prior to their development by any committee or approval by the [BID] board of directors." ${ }^{526}$ Finally, in a dramatic signal of its determination to monitor and control New York's BIDs, the city, citing persistent noncompliance with municipal directives, declined to renew the contract of the Grand Central Partnership to manage the city's largest BID in the summer of 1998.527

These actions effectively demonstrate that a city can vigorously oversee its BIDs and take the administrative actions necessary to translate formal legal control into real public accountability. Indeed, they raise the danger that the city may be too aggressive in its efforts to control the BIDs. The city must take care to assure that closer oversight does not strangle the ability of BIDs to undertake the initiatives in such areas as public safety, street cleaning, street furniture and design, public events and hospitality to visitors that have made such a contribution to urban

523. Some BIDs have adopted such policies. See, e.g., Deborah M. Clubb, CCC Adopts Rules to Help Avoid Conflicts of Interest, Memphis Com. Appeal, Apr. 10, 1998, at A1 (Memphis BID adopts a conflict of interest policy).

524. See Levy, supra note 170, at 22.

525. See Gabriel, supra note 459 , at 1 .

526. See Lentz, supra note 461, at 4 . The headline of this Crain's article appears to overstate just how far the new city policy restrains the BIDs.

527. See Lueck, supra note 135, at B1. 
life. Micromanagement of BID operations can be as damaging to urban governance as lax oversight and inadequate municipal control. ${ }^{528}$

The developments in New York City, which has more BIDs than any other locality in the country, indicate that cities have the legal capacity to effectively oversee BIDs. The real questions are political and pragmatic: whether cities will actually exercise their powers and seek to assure BID accountability, whether oversight staffs will be given adequate resources and whether elected governments can increase their monitoring without interfering with the ability of BIDs to implement their programs.

Similarly, the solution to the problem of BID accountability to district residents will require more active city monitoring and control. State laws should require that district residents and neighborhood organizations be given notice of a proposal to form or renew a BID and be invited to testify at public hearings considering these questions. ${ }^{529}$ Some seats on BID managing boards should be reserved for representatives of neighborhood residents or organizations. But given the financial basis of BIDs-their dependence on assessments imposed on property owners or firms within the district-it is inevitable that property owners or firms will want the dominant voice in determining whether they will be assessed and how their assessments will be spent. Certainly, it is highly unlikely that property owners would support a program that would subject them-and only them-to additional taxation without some guarantee, such as majority representation on the board that spends the money, that the additional taxes would go to programs that benefit them. As a result, it is up to the democratically elected city governments that create the BIDs to protect the interests of district residents. City governments have the legal authority to do so: The real issue is whether they have the will to take the legal and administrative steps necessary to oversee their BIDs.

Many of the measures that can increase accountability to city government-annual reports, outside audits, conflict of interest rules and sunset and reauthorization requirements-can benefit assessment payers as well. Cities should require BIDs to disseminate greater information to assessment payers concerning their programs, operations and the meetings and procedures of their managing boards. Cities should restrict the ability of BIDs to contract with organizations that are affiliated with BID managers and directors. Assessment payers would also benefit if the rules of BID formation and renewal required BID proponents-and the BID itself in a reauthorization proceeding-to demonstrate affirmative support from the district-level private sector before a BID could be established or renewed. As noted in Part I, although much of the popular literature concerning BIDs assumes that a majority of district businesses or property

528. See Thomas J. Lueck, The Mayor's Reach, N.Y. Times, Apr. 5, 1998, § 1, at 33 (quoting concerns of City Council Finance Committee Chair Herbert E. Berman over Mayor's directive requiring BIDs to report more frequently to the Department of Business Services).

529. See, e.g., D.C. Code Ann. § 1-2276(d) (1998). 
owners must vote to approve the creation of a BID, in many states there is no such requirement, and the formal role for district-level private interests is limited to vetoing a BID that has already been approved by the city legislature. A veto procedure puts a considerable burden on smaller property owners or businesses to find out about the proposed BID, organize and collect the necessary petition signatures-activities which must be carried out in a limited time period. District property or business interests would be better protected, and BID accountability to the district-level private sector promoted, if BID proponents had the burden of mustering the necessary show of support for formation and reauthorization of a BID. 530

The hardest issue of $\mathrm{BID}$-assessment payer relations derives from the public, not the private, nature of BIDs. Instead of undertaking classic assessment-funded activities that provide discrete benefits to individual payers in exchange for assessments tied to the particular payer's benefits, a BID provides services to a district as a whole. These are "public" services-public, that is, within the limited perimeters of the districts. With the nexus between a particular property owner's payment and benefit attenuated, the possibility arises that the property owners or businesses who control the BID can exploit weaker interests and use BID assessments to support programs which primarily benefit the dominant owners. Such a possibility is inherent in any institution with the power to coerce contributions. ${ }^{531}$ BID spending may favor some district interests over others because the BID may be too accountable to the small number of owners who pay the majority of a district's assessments. ${ }^{532}$ The only ways to prevent such tyranny by the BID majority are either to shift decisionmaking to the city government, to limit the range of BID activities to services characterized by a tight benefit-payment nexus or to eliminate

530. It is debatable whether business or property owner sentiment should be gauged by reference to the percentage of firms/parcels or the percentage of assessment payments. As noted in Part I, some states look to percentage of firms/parcels, some look to percentage of assessments or assessed valuation, and some look to both in determining the sufficiency of support for, or opposition to, BID formation. Similarly, some provide for the allocation of votes on BID boards according to assessments while others treat all firms or owners equally. Given that participation in formation and governance is limited to businesses or property owners because only they are subject to district assessments, there is some logic to scaling the weight of petition signatures and votes to the size of the assessment burden. On the other hand, property owners are often able to pass assessments along to tenants, so there may not be a correlation between assessment size and financial burden. Moreover, in some districts a small number of owners who pay a high proportion of the assessments may be able to dominate the BID to the detriment of smaller payers. Neither "one dollar, one vote" nor "one parcel, one vote" is a clearly compelling rule. The measure of property owner support may be more a matter of local politics, and of concentration in local property ownership, than a matter of principle.

531. "Exit" from the district is not an option unless the firm or owner wants to incur the costs of physically moving from the district or organizing with other firms or landowners to secure the district's termination.

532. Again, the assessment payer majority may refer to a majority of firms or parcel owners, or to the payers of a majority of a district's assessments. 
compulsory assessments. Any of these "solutions" could significantly undermine the ability of BIDs to take the initiative, provide area-wide services and improvements or function as structures for the articulation and implementation of district solutions to district problems. ${ }^{533}$ If any of these approaches were adopted, a BID would cease to be a BID, and the benefits of BID programs might be lost. Nor is it clear that such drastic action is necessary. Although the potential for internal exploitation exists, and some cases of abuses have been identified, there are relatively few reported incidents given the large number of BIDs.

At present, it does not appear that the problem of majority exploitation is so great as to require a drastic curtailment of BID financing or decisionmaking capacity. Sunset and reauthorization requirements, more active city oversight, controls on conflicts of interest of BID managers and directors and the greater dissemination of information concerning BID programs and finances to BID constituents ought to be sufficient to protect the interests of assessment payers. If not, and if the spread and maturation of BIDs demonstrate that the problem of exploitation is more serious than it has been to date, then cities will have to reconsider whether BIDs are an appropriate instrument for dealing with business district problems.

\section{B. BIDs and Inequality in Local Public Services}

BIDs almost certainly cause some inequalities in service delivery. In many cities, as part of the process of establishing a BID, the city government pledges that it will not reduce the services the district received prior to the formation of the BID. BID-financed services will be increments to existing city-provided services, so that BIDs receive more policing, garbage pickups, street cleaning and other services than the city government would otherwise provide.

Some BIDs complain that, such baseline services agreements notwithstanding, cities do cut back on municipal services, such as sanitation, once BIDs are in place. ${ }^{534}$ In those situations, district property owners pay more money for the same services they would otherwise receive, and cities are able to redeploy municipal resources from more affluent to less affluent areas.

Conversely, the existence of a BID may result in a district receiving more municipally provided services, and not just BID services. The controversy over the new police substation for the Wall Street area concerned the ability of a BID to use its funds to persuade New York City to redeploy city police resources in a manner more beneficial to the BID, and to en-

533. There are a small number of so-called "voluntary" BIDs-in effect, associations of area businesses or property owners who commit to contributing funds for hiring supplemental cleaning crews. See, e.g., Mayor Dennis Archer to Announce Detroit's First Downtown Business Improvement District Initiative, PR Newswire, Sept. 21, 1998, (visited Jan. 15, 1999) <http://dialog.carl.org> (on file with the Columbia Law Review).

534. See Cities Within Cities, supra note 181, at 79. 
able the Wall Street area to jump ahead of other neighborhoods that were seeking new substations but were counting on the city to pay for them. ${ }^{535}$ Less dramatically, BIDs are quick to discover neighborhood problems, like potholes and broken street lights, and are effective at reporting these problems to responsible city agencies and pressing for the necessary repairs. The BID is a sort of "ombudsman with resources" for forcing city agencies to do their jobs in BID areas. ${ }^{536}$

Except for municipal evasion of a baseline services agreement, the formation of a BID means an area will be receiving more services than it would have otherwise. If the area was not underserved in the first place, then the area will receive more services than a comparable non-BID neighborhood. More important, these services are based on the district's willingness and ability to pay, rather than on need for the service. Thus, the rise of BIDs creates a connection between neighborhood wealth and the quality of local public services. BIDs raise the troubling prospect of establishing a practice that could justify inequalities in public services among the different neighborhoods within a city based on neighborhood ability to pay. The local public service inequalities that BIDs create, however, may be mitigated by four factors.

First, BIDs are not so sharply distinct from their surrounding neighborhoods that only BID constituents benefit from BID-provided services. Most BIDs are commercial districts. In the words of the executive director of the Times Square BID, "BIDs are here to draw people into our neighborhoods." 537 They depend heavily on other city residents to come to the districts to work, to shop, to seek entertainment or to enjoy public amenities. Thus, all city people who come into the districts, whether or not they reside in the BID, benefit from BID programs that make districts cleaner, safer and more vibrant. ${ }^{538}$

Second, BIDs can benefit their cities as a whole. Most BIDs are located in downtown or central business district areas that attract workers and shoppers from the metropolitan area, tourists, convention-goers, and other visitors more broadly. Purchases made within BIDs increase city

535. See, e.g., More Police on Wall Street, supra note 210, at A18; Robert Polner \& Dan Morrison, A Cozy Union: Alliance's Links to City Officials Raise Eyebrows, N.Y. Newsday, Feb. 23, 1998, at A3. The political turmoil created by the news that BID funding would enable the Wall Street area to obtain a new police substation may have led to the city's decision to use city funds to pay for another new substation in a middle-class black neighborhood in Queens. See Lisa Rein, Queens to Get New Police Base, Daily News (N. Y.), Feb. 18, 1998, at 5.

536. Interview with Gretchen Dykstra, Executive Director of Times Square BID In New York, N.Y. (July 14, 1998).

537. See id.

538. Most BID programs are unlikely to have negative effects on surrounding areas. It is implausible to think that BID trash collection and street cleaning will displace litter elsewhere. It is conceivable that BID policing activities will cause criminal activity to shift to adjacent neighborhoods. There is not much evidence that this has occurred, but it is a possibility worth considering in evaluating the overall impact of BIDs on their cities. 
sales tax revenues; so, too, increased commercial activity within a BID enhances property values and, thus, can increase property taxes. BIDs seek to make downtowns and other commercial districts more competitive with suburban malls and edge city developments as sites for offices, stores, and entertainment and cultural activities. BIDs can draw new investment and businesses into the cities, or at least stanch the flow of commercial activity exiting the city. This provides the city with financial benefits and can provide a critical boost to urban morale. ${ }^{539}$

Third, existing measures of service need may understate the requirements of business districts. Commercial areas and downtowns have relatively few full-time residents, yet they attract enormous numbers of office workers, shoppers, tourists and visitors. As previously noted, the Grand Central area had fewer than one thousand permanent residents but more than 250,000 weekday working commuters, not to mention shoppers, tourists and other people who pass through the district without living there. As a result, their cleaning and policing needs are well out of proportion to their resident population. To the extent that the allocation of municipal services is based on population, these areas may actually be underserved, so that BID programs may be necessary simply to keep these areas adequately maintained.

Fourth, it would be wise not to exaggerate the level of inequality produced by BID expenditures. BID budgets are rather small compared to municipal budgets. In fiscal 1997, BID assessments in New York City, which has the largest BID program in the country, came to less than $\$ 50$ million-or less than two-tenths of one percent of the city's $\$ 34$ billion budget. ${ }^{540}$ Moreover, a part of BID spending is devoted to marketing, promotions and other direct business-related services that would be irrelevant to residential areas. The differences in service expenditures between BID and non-BID districts within cities are probably far less than the differences in expenditures between high-wealth and low-wealth municipalities in the same metropolitan area.

BIDs do produce service inequalities, but they can also shore up a municipality's tax base, provide services and public amenities that city residents, as well as businesses and property owners, can use and enjoy, and ultimately benefit the rest of the city. Most BIDs promote the general city interest in maintaining and revitalizing downtowns without the tax cuts, low interest loans or diversion of municipal treasury funds that have marked other downtown development programs in the last several decades. Certainly, it would be better to raise the quality of services within cities generally to bring all neighborhoods up to the level of the BIDs. But that is not likely to be an option in today's fiscally constrained urban environment.

539. See, e.g., Deborah Sullivan, Gauging Success: L.A. to Start Monitoring Districts, Daily News of L.A., Mar. 1, 1998, at N18 (Pasadena Director of Finance details sales tax and property tax revenue increases in Old Pasadena BID).

540. See Comptrollers' Audit, supra note 159, at 3. 
Downtown property owners are unlikely to support increases in the general level of city taxation as most of the added revenue would go to services outside business areas and to programs that do not benefit business activity directly. Instead, property owners unable to establish BIDs to finance supplemental services and improvements are likely either to (i) provide themselves with supplemental services privately, on an individual basis, through agreements among the largest owners, or through organizations like chambers of commerce; (ii) seek to use the local political process to divert general city revenues to the business districts; or (iii) give up on obtaining the additional services and relocate from the cities to those suburbs or exurban areas that provide better services, or at least comparable services at lower tax rates.

Under the third alternative to BIDs, the city would lose the taxes the businesses generate as well as the other benefits-such as employment and opportunities for shopping and entertainment-such businesses provide. Ultimately, the city would lose residents as well. This basically describes the postwar pattern of suburban rise and urban fall.

Under the second possibility, which basically follows the pattern of the downtown economic revitalization strategy of the postwar decades, business districts would get additional services but at a cost to other areas in the city - a cost largely avoided by BIDs' primary reliance on assessments imposed on property owners or firms within the business districts.

The first option, if successful, would provide the business districts the services they need. These services would be provided without the use of public funds, but there would still be service inequalities between the business districts and other areas. It is, however, difficult for any but relatively affluent landowners to furnish their own additional safety or sanitary services on an individual basis or through voluntary collective organizations. The few instances of "voluntary" BIDs involve areas where one or a small number of property owners own most of the property in the area. ${ }^{541}$ In other situations, coordinating large numbers of owners and overcoming the free rider problem without coercive taxation are likely to pose insuperable difficulties. Moreover, should a voluntary BID succeed, the inequality problem would also be created. The BID's access to the mechanism of public taxation means that it will be more effective than a chamber of commerce in collecting funds, but the result is no more une-

541. See, e.g., Deutsch, supra note 105, at 9 (the Durst Organization, a commercial realtor in New York, "laughingly" operates a "DID-the Durst Improvement District," which provides patrolling and cleaning services to the city blocks adjacent to its midtown office buildings). In the area around the University of Pennsylvania in West Philadelphia, the University, which is the principal property owner in the neighborhood, has taken the lead in organizing other universities, hospitals, not-for-profit organizations, and governments that own property but are tax-exempt and thus, under Pennsylvania law, cannot be assessed for a BID into a BID-like entity. Eighty percent of the $\$ 3.4$ million budget for this University City District is provided by five-year contractual commitments of the dozen largest property owners, led by the University. See Paul Stahnke, Conference on BIDs (May 3, 1998). 
qual than if these services were provided by a voluntary organization of neighborhood landowners or businesses.

At present, BIDs produce relatively limited inequalities, and these inequalities may be justified by the benefits BIDs provide their cities. The real inequality concerns posed by the rise of BIDs are more long-term. First, the existence of BIDs could lead businesses and property owners in commercial areas to use BIDs to provide more of the services their areas receive. They would then reduce their support for existing levels of general taxation. If business areas could fund more of their services through district taxes, they might seek to lower general municipal taxes, thereby reducing revenues available for services elsewhere in their cities. This could drive down the baseline level of city services and thus increase the degree of inequality between BID and non-BID areas, and between more affluent BIDs and their poorer cousins.

Second, although BIDs are reserved for areas where the primary property uses are business-related, the districts could become a model for other types of special assessment or special service districts that would serve upper-income residential areas. Park advocates have proposed the creation of "park enhancement districts" that would apply the BID model to parks in residential areas. ${ }^{542}$ In New York City, Upper East Side real estate interests, citing the successes of BIDs, proposed the creation of an Upper East Side Security District that would have collected supplemental assessments to fund additional security for that affluent residential neighborhood. ${ }^{543}$ Although the proposal ultimately foundered in the face of intense opposition-including opposition from within the proposed district ${ }^{544}$ - a similar neighborhood security district, funded by neighborhood-level assessments, was created by the city of Chicago for the Marquette Park neighborhood after years of pressure by neighborhood residents. ${ }^{545}$ Neighborhood "tax election districts," in which property owners subject themselves to additional taxes to pay for extra police patrols, appear to be in use in Louisiana as well. ${ }^{546}$

Together, the expanded use of BIDs in business areas and the development of BID-like entities in residential areas could undermine the norm of equality in the provision of urban public services. In large cities, citywide taxes provide for a measure of redistribution from more affluent neighborhoods to poorer areas. Taxes are usually based on some measure of ability to pay, such as property values or incomes, while "the legal

542. See BIDs, PEDs, and Special Districts: A Better Way to Pay for Parks? GreenSense: Financing Parks and Conservation, Spring 1995, at 1.

543. See Joyce Purnick, Plan for Private Police Force Sets off Alarms on Upper East Side, N.Y. Times, May 29, 1995, at A25.

544. See, e.g., Bruce Lambert, Private Security Proposal is Fading, N.Y. Times, July 9, $1995 \S 13$, at 6; Purnick, supra note 543, at A25.

545. See Phillip J. O'Connor, Marquette P. Guards Yield First Arrests, Chi. SunTimes, June 1, 1995, at 6 .

546. See Deann Smith, Crime-wary Neighborhoods Passing Taxes for Protection, Baton Rouge Advocate, Oct. 11, 1998, at A1. 
doctrine of equal service provision presumptively obligates the [city] government to offer the same level of service to all residents." 547 The doctrine of equal service provision is not often judicially enforced, and in some cities, some areas are, no doubt, better served than others. But this may be due to bureaucratic decision rules or municipal politics rather than formal city policy. In general, "municipal governments more often ... achieve a rough equivalence of service packages among their neighborhoods." ${ }^{448}$ If BIDs were to lead to more neighborhoods providing more of their own services out of neighborhood resources, this could create within city boundaries the interlocal, and especially, city-suburb, public service inequities characteristic of most American metropolitan areas. ${ }^{549}$

This specter of intracity metropolitanization is difficult to assess. At present, BID functions are restricted, and BID budgets are just a small fraction of city taxes, with assessment levels often tightly limited by state law. There are huge categories of local government expenditures, such as education, that are entirely outside the bailiwick of BIDs. Downtown interests have generally resisted redistributive taxation. Although the existence of a BID might stiffen commercial district opposition to general municipal taxation, it is unclear whether those interests would have the political clout to drive down the general level of taxation for the support of city services-after all, it was their inability to obtain more general city revenues for business district services that led them to champion the selfassessment that BIDs entail.

BIDs pose much less of a threat of service inequality than would the extension of the BID model to residential areas. ${ }^{550}$ To be sure, residential neighborhoods, in which property ownership is widely dispersed, are likely to be harder to organize than commercial districts, and homeowners unable to shift the supplemental assessments on to tenants or customers may be more resistant to paying additional charges. In many jurisdictions, there is no current legal authorization for residential improvement districts. Still, the Marquette Park and Louisiana police district examples suggest that residential BIDs can be created. If the residential version of the BID were to be more widely authorized, it might spread; with more people benefiting from both BIDs and residential special services districts there could be a greater constituency for driving down the level of gen-

547. Clayton P. Gillette, Opting Out of Public Provision, 73 Denv. U. L. Rev. 1185, 1197 (1996).

548. Robert L. Lineberry, Equality and Urban Policy: The Distribution of Municipal Public Services 181 (1977).

549. See, e.g., Richard Briffault, Our Localism: Part I-The Structure of Local Government Law, 90 Colum. L. Rev. 1, 18-39 (1990) [hereinafter Briffault, Our Localism I] (the quality of local services can vary tremendously from locality to locality within a metropolitan area according to the taxable wealth of each locality).

550. As one commentator observed, New Orleans, which has taken the lead in establishing residential policing districts, was also one of the first cities in the United States to create a business improvement district. See Smith, supra note 546, at A1. 
eral municipal taxation and shifting responsibility for the provision of municipal services to BIDs and residential improvement districts (RIDs). ${ }^{551}$ If RIDs, like BIDs, were to be funded primarily from district assessments, that really would be a formula for reproducing city-suburb fiscal inequities within cities. ${ }^{552}$

There is much less justification, in terms of the well-being of a city as a whole, for a RID than for a BID. RIDs are unlikely to be places in which other city residents work, shop or seek entertainment, so other city residents would not benefit directly from RID amenities in the way they benefit from BIDs. Similarly, residential districts are unlikely to draw shoppers, tourists or workers from outside the city, so there is less benefit to the city's tax base. Still, RIDs could provide city residents with an alternative to exit to the suburbs, and, thus, they could help cities hold on to their more affluent residents. So long as residents in these areas are subject to general municipal taxation, RIDs might have some benefits for the municipal fisc. It would be a more difficult question whether the service inequalities attendant on RIDs, and the challenge to the norm of equal service provision within municipal boundaries, could be justified in terms of the benefits to the city as a whole of the retention of middle- and upper-income residential taxpayers.

The service inequalities currently produced by BIDs are relatively modest - they are far less than the inequalities that mark city-suburb relations-but the rise of BIDs has disquieting implications for the future of urban public services. With politically fragmented metropolitan areas and cutbacks in intergovernmental assistance, cities are largely left to their own devices. They depend on their own resources to fund services for their residents. As a result, a city must attract and retain businesses and more affluent residents in order to maintain its tax base. Businesses and more affluent residents, however, are likely to demand better services, and they are more capable of exiting to suburban communities where better services at lower taxes are available if their demands for better municipal services are not met. BIDs offer a mechanism for providing better services without raising general tax rates, but at the price of producing some intracity inequality and undermining the notion that public services are to be distributed within a city based on criteria other than ability to pay.

551. For a proposal for small-scale residential "block-level improvement districts" (BLIDs), see Robert C. Ellickson, New Institutions for Old Neighborhoods, 48 Duke L.J. 75 (1998).

552. One way to mitigate the inequalities such districts would create, and to make the residential neighborhood improvement district an option for low-income neighborhoods, would be for city governments to match neighborhood-based assessments with a contribution of municipal treasury funds. The city-neighborhood matching formula could be on a sliding scale so that funds raised in the poorest neighborhoods would be subject to the greatest city multiplier. Such a program could provide an incentive to, and a reward for, efforts by poorer neighborhoods to organize themselves. 
As the fiscal and service pressures on municipalities grow, and the "lesson" of BIDs spreads, more municipalities and more urban neighborhoods could turn to BID-like structures. Should that occur, cities would be faced with an increasing tension between the norm of service equality and the reality that some inequality may be necessary to secure the tax base necessary to provide the funds to pay for more basic levels of services for poorer residents. Some trade-off between equality of services and adequacy of service may become a central feature of urban politics and finance. Greater intracity service inequalities may become necessary to hold down interlocal, especially city-suburb, inequalities. BIDs per se are not a significant source of inequality but they are a warning that the combination of interlocal competition for tax base, sharp interlocal inequalities in the distribution of taxable wealth, and local dependence on local wealth to fund local programs has placed the norm of urban service equality under siege.

The anxiety about BIDs also reflects a legitimate concern about the quality of municipal services, particularly in poorer, working class and middle class areas. ${ }^{553}$ BID-funded inequalities might be acceptable if the basic level of services city residents receive was considered adequate. When everyone is receiving appropriate levels of policing, street cleaning and street repair, park maintenance and other municipal services, then it might be acceptable to enable those areas wishing to pay more taxes in exchange for additional services to do so. But where services are perceived to be inadequate, BID-funded inequalities become very troubling. Moreover, if BID and BID-like devices enable businesses and property owners in commercial areas to solve their own service delivery problems without attending to the needs of the rest of the city, then there is also a danger that the business community, which has historically been a major force for urban political action, will no longer even be interested in city service issues.

At this point, BIDs are more a consequence than a cause of the erosion in the quality of urban services. Indeed, by reminding city residents and businesses of just how important high-quality services are to urban quality of life, BIDs could stimulate new fiscal support for public services. Alternatively, by cushioning the impact of municipal cutbacks on more affluent areas, BIDs and BID-like entities could eventually contribute to a reduction of general tax base support for public services. The impact of BIDs on public service levels outside the districts needs to be closely watched and carefully assessed as the number of BIDs grow, and as existing BIDs become part of the long-term structure of urban governance.

553. See, e.g., Kessler v. Grand Cent. Dist. Mgmt. Ass'n, 158 F.3d 92, 131-32 (2d Cir. 1998) (Weinstein, J., dissenting). 


\section{Conclusion: BIDs and the Urban Public Sphere}

Many commentators have characterized BIDs as a form of privatization that encroaches on the urban public sphere. This claim of privatization has two strands. First, "private" refers to the private sector. With private property owners and businesses playing the leading role in setting BID goals and managing BID operations, critics fear that BIDs represent another front in the steady ideological advance of the private, and retreat of the public, sector that has marked the debate over governance in the last quarter-century. ${ }^{554}$ From this perspective, the successes of BIDs in cleaning streets, improving safety and providing amenities, in counterpoint to the asserted failures of municipal government, are troubling because they threaten to delegitimate the local public sector. Second, "private" refers to the tight focus of BIDs on activities and services within their districts, and especially the reservation of BID revenues for the limited purpose of benefiting the BID rather than the broader "public" of the city as a whole. ${ }^{555}$ This view of BIDs may acknowledge their status as governments, but, related to the concern that BIDs promote intralocal inequality, it stresses their parochial focus on the needs and concerns of smaller, and more affluent, enclaves. BIDs privatize in the sense that they balkanize their cities, as well as in the sense that they transfer power to the private sector. Taking the two strands together, BIDs-like the gated residential communities with which they are often linked-are said to "raise larger questions about the meaning of community and the public realm in contemporary America."556

There is more than an element of truth to both aspects of the privatization critique. BIDs give a considerable formal role to private sector interests, and they often present themselves as private or quasi-private entities. BID management entities are designed to resemble corporate firms. BIDs pursue quasi-corporate marketing strategies, and some look to such private sites as shopping malls or Disney World as models for a new urban order. Moreover, BIDs are focused on the particular interests of their districts.

Nevertheless, this privatization critique is overstated. It misses the considerable public role in creating, empowering and controlling BIDs. Moreover, the privatization claims exaggerate the extent to which BIDs represent a departure from local governance generally. Private interests have been powerful forces within local governments, and the philosophy of localism - that is, the empowerment of small, narrowly-focused political units-has been central to the law and politics of American local gov-

554. See Lasdon \& Halpern, supra note 21, at A29. sphere).

555. See Wolfson, supra note 41, at 21 (discussing how BIDs "narrow" the public

556. Stark, supra note 22, at 64. More hyperbolically, the rise of BIDs has been linked to the emergence of militias and of home schooling as "signs of sickness" of our public institutions. See Sheri Berman, Civil Society and Political Institutionalization, 40 Am. Behav. Sci. 562, 571 (1997); Stengel, supra note 43, at 35-36. 
ernment. Finally, it is not clear that a limited private role and a sharp public/private separation is necessary to promote the urban public realm. By promoting the public's use and enjoyment of the streets, parks, squares and other public spaces that are at the heart of urban living, BIDs-whatever their place on the public-private continuum-can enhance the public environment and contribute to an enrichment of the public life.

First, BIDs are public entities. Their most critical power, the power that distinguishes them from chambers of commerce and downtown business partnerships and that is most responsible for their effectiveness, is the public power of coercive taxation-a power generally wielded by municipalities on the BIDs' behalf. BIDs are created by public governments in a process in which their boundaries, programs, finances and governance structures are shaped by government decisions. The best argument for exempting BIDs from one person, one vote is that the districts are subordinate to city governments. So, too, one of the reasons BIDs have succeeded in repelling state constitutional challenges to their assessments is the state court practice of deferring to city decisions concerning assessments. The successes of BIDs in raising funds and delivering services are as much a testimony to the ingenuity of the public sector in designing public institutions and enabling them to secure new resources for the support of public amenities as evidence of the supposed superiority of private enterprise over public efforts.

Second, neither the role of private sector interests nor the narrowing of public focus on discrete districts make BIDs radically more "private" than other forms of local government. Private property owners and firms have long played a leading role in organizing local governments. ${ }^{557}$ As noted in Part II, many localities are special purpose governments designed to provide special benefits to landowners, and are formally controlled by landowners. Property owners also play an important role in general purpose local governments because of local governments' reliance on property taxes for local revenues. ${ }^{558}$

All local governments are in some sense private, relative to the states and the nation, because of their small size, legal independence and political accountability to local constituencies. Local governments are public institutions, but each locality is designed to pursue the interests of a fairly small fragment of the public. As a rule, local governments are relatively autonomous with respect to finances, service delivery, regulatory authority and political control. Local governments are largely dependent on their own resources for revenue. Certainly, more affluent localities have little or no obligation to provide financial assistance to their neighbors. Many localities are incorporated simply to deny surrounding areas access

557. See, e.g., Burns, supra note 331, at 98-108 (1994).

558. See, e.g., Dick Netzer, Property Taxes: Their Past, Present and Future Place in Government Finance, in Urban Finance Under Siege 51-56 (Thomas R. Swartz \& Frank J. Bonello eds., 1993). 
to local taxable resources. ${ }^{559}$ Local governments may engage in exclusionary zoning or impose impact fees to keep out newcomers who would cost the communities more in additional public services than they would provide in new taxes, much as they deploy their tax and zoning powers to induce new investment that would expand their tax bases. ${ }^{560}$ The nature of local governance further contributes to parochialism since local officials are elected by people physically resident within local boundaries. Although local governments are nominally creatures of the state, local electoral control tends to increase the salience of local interests, rather than the broader regional or state public interest, in local government decisionmaking.

Even the most "public" of local governments-the cities and counties that provide services to their entire population and whose elections are subject to one person, one vote-are relatively "private" from the perspective of a metropolitan area or state. These local governments are characterized by different levels of service reflecting differences in local wealth and by political accountability to distinctly local constituencies rather than to the broader metropolitan area that may be affected by local actions.

All local governments, then, are composed of public and private elements, with the private deriving from small population and territorial size-relative to state or metropolitan area-as well as from the longstanding fiscal connections to landowners. BIDs have a greater "private" component than the city governments that create them. They are territorially sublocal and organizationally focused on the interests and concerns of landowners or firms. Yet, they are not fundamentally different from other forms of local government. Indeed, as indicated in Part II, as a formal legal matter, BIDs are in a sense simply a new type of special district.

Despite the concern about BIDs as privatization, BIDs have far less power than local governments generally, and they are far less independent of their cities than local governments are of their states. Under general incorporation laws, local residents may be able to create local governments without obtaining the approval of the state or of existing local governments affected by the incorporation of a new locality. ${ }^{561}$ Local governments possess independent regulatory authority, particularly over land use. ${ }^{562}$ Land and people within one local government are generally exempt from taxation by other local governments. ${ }^{563}$ By contrast, BIDs

559. See Burns, supra note 331, at 37-40, 80; Gary J. Miller, Cities By Contract 15-16, 76-82 (1981).

560. See, e.g., Mark Schneider, The Competitive City: The Political Economy of Suburbia 125-75 (1989).

561. See, e.g., Briffault, Our Localism Part I, supra note 549, at 74 (explaining municipal incorporation procedures).

562. See id. at 19.

563. See Briffault, Boundary Problem, supra note 48, at 1129. 
generally lack the power to create themselves, expand their programs, or unilaterally increase their tax bases. Many have limited terms, and nearly all lack regulatory authority.

BIDs may produce a degree of balkanization within cities, but so far they have caused far less inequality, parochialism, and fiscal and service fragmentation than is characteristic of interlocal relations in most metropolitan areas in the United States. Unlike metropolitan area local governments, BIDs are subject to a powerful "metropolitan" governmentthe city government that creates them, defines their programs, controls their funding, and, if so inclined, oversees their operations. The private qualities of BIDs are thus limited and subject to constraint in a way that the private qualities of most local governments are not. Indeed, the cityBID relationship could provide a model for the structure of metropolitan governance in which a strong regional body would define the powers, monitor the actions, and finance and provide the bulk of regional services, while subunits provide supplemental, self-funded services to discrete areas. Governance in metropolitan areas would be far more consistent with public values if metropolitan area local governments were as limited and subordinate as BIDs are.

Third, and most importantly, BIDs can contribute to the well-being of the local public sphere. The public sphere does not consist solely of government decisionmaking. It includes the interactions of people outside the familiar circles of family, friendship, work or membership organizations. Public life entails a "fluid sociability among strangers and near-strangers," arising out of the "ongoing intercourse of heterogeneous individuals and groups." ${ }^{64}$ The public sphere, in this sense, includes the places in which strangers can gather, mingle, and be comfortable with each other.

Cities have, historically, provided the physical settings-the streets, sidewalks, parks, squares, town commons and civic centers-where interactions among strangers have occurred. ${ }^{565}$ But to be effective in offering opportunities for the public sociability that is essential to public life, cities need to do more than provide spaces that are open to the public. Streets and other public places must be safe, ${ }^{566}$ orderly, ${ }^{567}$ clean and inviting if they are to succeed in actually serving as settings for public life.

564. Jeff Weintraub, "The Theory and Politics of the Public/Private Distinction," in Public and Private in Thought and Practice: Perspectives on a Grand Dichotomy 17 (Jeff Weintraub \& Krishan Kumar eds., 1997).

565. See Jerry Frug, The Geography of Community, 48 Stan. L. Rev. 1047, 1077 (1996) (noting that one way cities should serve as community-builders is through cultivation of bonds between strangers).

566. As Jane Jacobs has noted, "[ $t]$ he bedrock attribute of a successful city district is that a person must feel personally safe and secure on the street among all these strangers." Jacobs, supra note 54 , at 30 .

567. On the importance of disorder in driving people away from urban areas, see Wesley G. Skogan, Disorder and Decline: Crime and the Spiral of Decay in American Neighborhoods 21-84 (1990). 
That is what BIDs do. By providing the political and economic resources for such mundane matters as trash collection, street cleaning, graffiti removal, policing, assistance to tourists, special events, public entertainment, and amenities like fountains, trees, flowers and street furniture, BIDs help to create public places, or ráther, they make nominally public places truly open, accessible and appealing to the public. They contribute directly to the physical-social infrastructure of urban public life. Indeed, their successes are a reminder of just how much public life depends on the commitment of resources to maintaining and enhancing public spaces.

Public space and publicly-owned spaces are not the same thing. Some of the most successful public spaces-successful in the sense that they contribute to a flourishing public life-are privately owned, such as the English pub, the French sidewalk café, the Viennese coffee house, the German beer garden, ${ }^{568}$ or, closer to home, Rockefeller Center, South Street Seaport, the Quincy Market Place or the Columbia University campus. Such places, open to the public, can be "inclusively sociable, offering both the basis of community and the celebration of it." 569 As Jane Jacobs has noted, "the sight of people attracts still other people;"570 public life requires activity in public. Stores, bars and restaurants draw people out of their houses and into the streets, and that, in turn, will attract more people whose intention and interest has been piqued by the people gathered in both private establishments and on the public streets.

By the same token, dirty, dilapidated and dangerous streets, squares and parks are effectively closed to the public even if they are publicly owned and nominally open. Disorder and physical decay drives people off the streets and into their homes. ${ }^{571}$ Indeed, order maintenance has become an increasingly important goal in contemporary public policing. ${ }^{572}$

BIDs may pose some risks to public life. The notion of what constitutes order in public places may be sharply contested. ${ }^{573}$ BIDs may seek to advance a particular vision of public space and of the urban public that is not shared by all members of the public. As one critic has noted, “[p]roperty values lie at the heart of the BID's drive for public improvement." ${ }^{574}$ Their promotion of property values may result in a form of commercial gentrification, with the stores that serve poor and working

568. See Ray Oldenburg, The Great Good Place xv-xvii (1989).

569. Id. at 14.

570. Jacobs, supra note 54 , at 37 .

571. Skogan, supra note 567 , at $21-50$.

572. See, e.g., Livingston, supra note 209, at 562-91 (discussing the role of community and problem-oriented policing in ameliorating neighborhood disorder).

573. But cf. Skogan, supra note 567, at 21-50 (asserting that understandings of what counts as disorderly behavior are widely shared across middle class and poor communities).

574. See Zukin, supra note 23, at 67. 
class customers displaced by more upscale shops. ${ }^{575}$ Similarly, a BID's pursuit of order and security may involve efforts to drive out street people, peddlers, some forms of entertainment, even garish signs. Where one group or class finds a festive bazaar atmosphere, another group or class may see social and visual anarchy. BIDs may represent and advance the views of the latter group at the expense of the former.

The privatization that BIDs may produce is not so much private sector or even neighborhood-level control of public space but the extension of the "Disney World values of cleanliness, security and visual coherence" 576 to public streets, sidewalks, squares and parks. The success of Disney World and similar private developments suggests those values are shared by a considerable portion of the public. ${ }^{577}$ As the new urban policing's focus on order maintenance strategies and quality of life offenses demonstrates, this emphasis on order is increasingly influential within the local public sector generally, and not just in BIDs. Nevertheless, these values may not be shared by everybody. The urban public, or at least some classes and groups that make up the urban public, may be willing to tolerate a little more disorder than other people. Many urban residents welcome the increased sense of order and safety while also regretting the loss of variety, the disengagement from the urban reality of poverty and conflict, and the absence of what Paul Goldberger has called "the harsher edge of traditional urban environments." 578 Although the "new urban paradigm" of cities that are cleaner and safer but also "flatter and duller"579 is not limited to BIDs, the districts have played a role in the development of this new strand in urban policy. The dominant role of property owners, the dependence on special assessments, and the statutory goal of enhancing the business climate may incline BIDs to adopt order maintenance programs that are more restrictive than the policies of municipal governments and that may make public areas less attractive to parts of the public.

The possibility that BIDs will reshape public spaces to exclude parts of the public is real, but it is likely to be mitigated by their lack of formal regulatory authority and by local government oversight. BIDs may pursue Disney World values, but they lack Disney World's legal authority. BIDs are neither private organizations nor independent governments. BIDs do not own the streets, sidewalks, parks or downtown areas that they manage, and they cannot limit access to the areas within their jurisdiction. 580 Similarly, BIDs lack the power to zone, to prohibit land uses or to

575. See id. at 211.

576. Id. at 67.

577. See Witold Rybczynski, City Life: Urban Expectations in a New World 216-17 (1995) (celebrating the "unsophisticated version of urbanity" found in shopping malls).

578. Goldberger, supra note 379, at 145 .

579. Id. at $145-46$.

580. Cf. Zukin, supra note 23, at 54-55 (Disney admits the public on a paying basis; " $[t]$ his is the model of urban space driving the public-private BIDs"). 
criminalize behavior. BIDs may supplement the ability of local government to enforce existing rules, press for more effective enforcement by the police or other local officials and lobby for new laws that advance the BID vision of urban public order. But BIDs lack the power to enforce a vision of public order more restrictive than that permitted by state and local law, and they require local government support to realize their efforts to change the definition of public order.

$$
* * *
$$

The Business Improvement District is very much a government of our time. Its existence is largely attributable to the fiscal squeeze that has gripped most cities in recent decades and to the intense competition cities face from suburban malls, and from each other. BIDs' focus on services-on creating safe, clean and inviting public spaces-reflects and reinforces the growing contemporary concern with quality of life in urban government. Local governments are giving new and increasing attention to such issues as the maintenance of public order, the management of public places ${ }^{581}$ and the stimulation of activity in public streets, squares and parks. ${ }^{582}$ BIDs are central players in the effort to revitalize downtowns through the provision of services that make downtown public areas more appealing to people. This services strategy often has its harsh side, as the crackdowns against vagrants, beggars and peddlers suggest. But it is a strategy pursued by BIDs and city governments alike-and often together. ${ }^{583}$

The BID's combination of public and private elements seems very much of our time as well. This is an era of experimentation, of redefining the borders of public and private, of searching for new ways of utilizing private self-interest to address public problems. ${ }^{584}$ BIDs involve both the private sector turning to the public sector to obtain the benefits of the public power of taxation to override the free rider problems in funding services in business areas, and the public sector turning to the private sector to provide funds, above the levels of general taxation, to revitalize those city districts that are crucial settings for urban public life.

581. See, e.g., Kelling \& Coles, supra note 35, at 194-95 (describing Baltimore's “order-restoration program," San Francisco's "Operation Matrix," and Seattle's "carefully crafted ordinances targeting disorderly behavior on sidewalks"); Livingston, supra note 209, at 562-64 ("In community policing, the community, rather than police professionalism and the law, becomes a principal source of legitimation for many police efforts directed at ameliorating disorderly conditions.").

582. See generally Frieden \& Sagalyn, supra note 339, at 171-316.

583. See, e.g., Kelling \& Coles, supra note 35, at 199-200 (discussing BIDs' and city governments' restoration efforts in Baltimore).

584. See John D. Donohue, The Privatization Decision: Public Ends and Private Means 99-211 (1989); David Osborne \& Ted Gaebler, Reinventing Government: How the Entrepreneurial Spirit is Transforming the Public Sector 76-107, 280-310 (1992) (discussing the benefits of competition and market-based ideology in government-run industries). 
This intermingling of public and private elements raises difficult legal and policy questions. It presses against the rules governing local voting rights and local government finances, and it challenges norms concerning the democratic control of urban government and the equal treatment of urban residents. BIDs represent a compromise, a trade-off of basic values in urban governance. They provide a means of improving the quality of urban public services and enhancing urban public spaces, while avoiding legal and political limits on tax increases. They also provide for an increased formal role for private sector interests, limited intralocal service inequalities and the potential to undermine the norm of equal service provision.

At this point, the public benefits outweigh the costs. This could change as BIDs spread and develop. Certainly, individual BIDs may abuse the public trust, and, more importantly, municipal governments may fail in their duty to oversee their BIDs. Nor does the success of the particular mix of public and private interests, values and concerns validate all other contemporary public-private hybrids. Even though BIDs and gated communities are frequently bracketed together, BIDs are not gated communities. The public sector plays a greater role in their formation and in monitoring their operations. Moreover, by devoting attention and financing to urban public spaces, BIDs can enhance urban public life.

On balance, BIDs have been net contributors to urban public life. But, perhaps more important than whether my normative evaluation of BIDs is right or wrong, BIDs embody certain trade-offs-business district autonomy versus city government control, intralocal inequality versus interlocal competitiveness-that reflect the fundamental dilemmas of contemporary urban governance. Both the intermingling of public and private elements and the trade-offs that shape the laws and administrative arrangements that structure the operations of the business improvement district make it very much a government for our time. 